Pacific Northwest National Laboratory

Operated by Battelle for the

U.S. Department of Energy

\title{
Characterization of Offgas Generated During Calcination of Incinerator Ash Surrogates
}

\author{
J. K Luey \\ J.G. Darab \\ T. S. Autrey \\ J. D. Vienna \\ H. L. Wigent
}

January 1999

\section{RECEIVED FFP 171999 \\ $0=1$}

Prepared for the U.S. Department of Energy under Contract DE-AC06-76RLO 1830 


\section{DISCLAMMER}

This report was prepared as an account of work sponsored by an agency of the United States Government. Neither the United States Government nor any agency thereof, nor Battelle Memorial Institute, nor any of their employees, makes any warranty, express or implied, or assumes any legal liability or responsibility for the accuracy, completeness, or usefulness of any information, apparatus, product, or process disclosed, or represents that its use would not infringe privately owned rights. Reference herein to any specific commercial product, process, or service by trade name, trademark, manufacturer, or otherwise does not necessarily constitute or imply its endorsement, recommendation, or favoring by the United States Government or any agency thereof, or Battelle Memorial Institute. The views and opinions of authors expressed herein do not necessarily state or reflect those of the United States Government or any agency thereof.

\section{PACIFIC NORTHWEST NATIONAL LABORATORY \\ operated by \\ BATTELLE \\ for the \\ UNITED STATES DEPARTMENT OF ENERGY \\ under Contract DE-ACO6-76RLO 1830}

Printed in the United States of America

Available to DOE and DOE contractors from the

Ofrice of Scientific and Technical Information, P.O. Box 62, Oak Ridge, TN 37831; prices available from (615) $576-8401$.

A vailable to the public from the National Technical Information Service, U.S. Department of Commerce, 5285 Port Royal Rd, Springfield; VA 22161 


\section{DISCLAIMER}

Portions of this document may be illegible in electronic image products. Images are produced from the best available original document. 
PNNL-11982

UC-2000

\section{Characterization of Offgas Generated During Calcination of Incinerator Ash Surrogates}

J. Luey

J.G. Darab

T.S. Autrey

J.D. Vienna

H.L. Wigent

January 1999

Pacific Northwest National Laboratory

Richland, Washington 99352 


\section{EXECUTIVE SUMMARY}

The Pacific Northwest National Laboratory (PNNL) has completed a set of tests using a bench top rotary calciner and surrogates for Rocky Flats incinerator ash. The purpose of testing was to identify the composition of the offgas generated during the calcination processing step and, from these data, recommend appropriate offgas treatment systems. In addition, testing was performed to develop suitable end point criteria for the calcination processing step such that subsequent vitrification processing could be performed with a significant reduction in process upsets and increased process reproducibility. Laboratory testing was performed in conjunction with the rotary calciner work to better understand the mechanisms of offgas generation.

Results from the bench top rotary calciner should be taken in the correct context, namely: that observed trends are expected to hold true at full-scale operations, but equipment-specific data such as processing rates, inlet gas flow rates, solid to gas contact, and offgas concentrations may not directly scale. It is recommended that the results from the bench top rotary calciner be used in establishing test criteria to evaluate prototypical full-scale equipment, and not as a means of estimating full-scale equipment performance.

Tests were performed on six different ash surrogates, including three materials generated in medical and commercial incinerators; and three synthetic mixtures with compositions within the limits identified for actual incinerator ash material, but which were not thermally processed.

Testing was performed at $700^{\circ} \mathrm{C}$ to be consistent with batch calcining experiments performed by PNNL in fiscal year 1997. Air and pure oxygen were injected in varying proportions to provide the necessary oxygen to process the carbonaceous material. Helium was used as a tracer to allow quantitative determination of the amount of gas produced during calcining.

Trends and results observed during the calcination tests are summarized below.

- An end point criterion based on offgas composition results in an acceptable treated ash product that processes well in the vitrification step. The end point used for testing was the return of carbon dioxide levels to background concentrations.

- Primary gases generated during calcination are carbon monoxide and carbon dioxide with the latter species dominating. Hydrogen levels were typically below $2000 \mathrm{ppm}$. Minimal concentrations of methane were observed. Other gases were detected but were not quantified and/or identified against a known standard. 
- Increasing the flow rate of oxygen to the system reduces the amount of time required for calcination. Pure oxygen was used in combination with air because gas flow through the bench top calciner is limited by particulate carryover. As expected, increasing the oxygen levels generated predominately carbon dioxide rather than carbon monoxide.

- The concentration of carbon monoxide (and carbon dioxide) can be controlled by adjusting both the flow rate of oxygen and the kiln temperature. Reduction of carbon monoxide levels is achieved by reducing calciner processing temperature and increasing inlet oxygen flow.

- Results of laboratory tests on individual carbon-containing species differed from the results obtained on ash surrogates spiked with carbon-containing materials. The main difference was the presence of more types of offgas components from calcination of individual carbon source relative to a mixture of sources. This suggests that the reactions during calcination are more complex for the ash surrogates than for the individual carbon species; and would be expected to be still more complex for actual incinerator ash. 


\section{CONTENTS}

EXECUTIVE SUMMARY

CONTENTS

iii

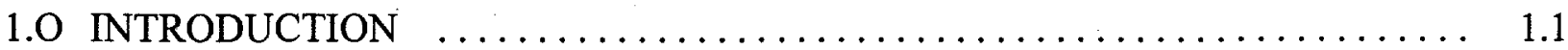

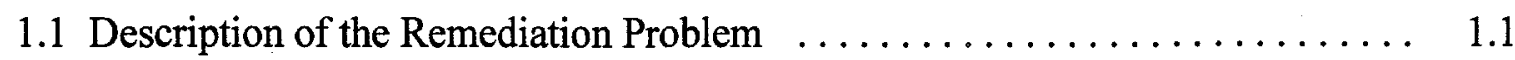

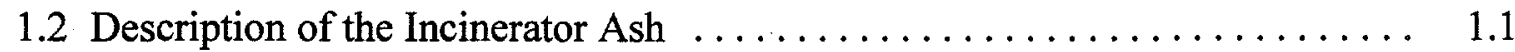

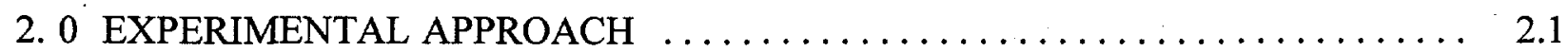

2.1 Literature Review $\ldots \ldots \ldots \ldots \ldots \ldots \ldots \ldots \ldots \ldots \ldots \ldots \ldots \ldots \ldots \ldots . .1$

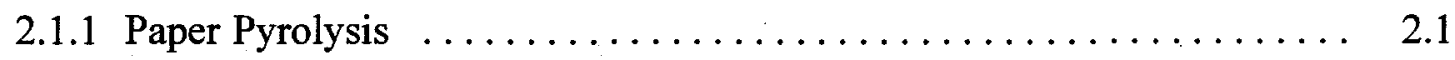

2.1.2 Polypropylene, Polystyrene, and Polyvinylchloride $\ldots \ldots \ldots \ldots \ldots .2 .2$

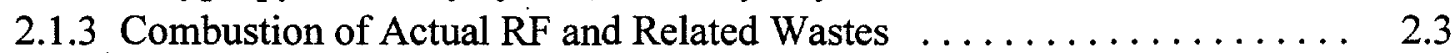

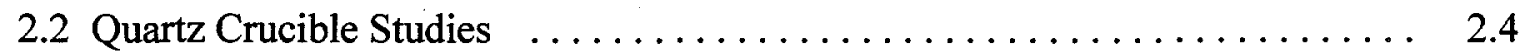

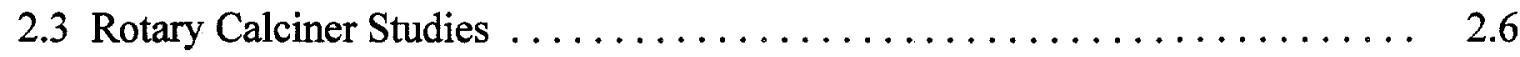

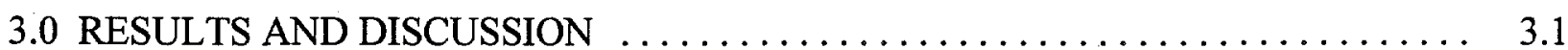

3.1 Quartz Crucible Measurements $\ldots \ldots \ldots \ldots \ldots \ldots \ldots \ldots \ldots \ldots \ldots \ldots \ldots . . .1$

3.1.1 Tests of Carbon Components in Oxygen and Helium ........... 3.2

3.1.2 Tests of Ash Surrogates in Oxygen and Helium $\ldots \ldots \ldots \ldots \ldots \ldots . . .5$

3.1 .3 Tests of Carbon Components in $100 \%$ Helium $\ldots \ldots \ldots \ldots \ldots \ldots . . . .6$

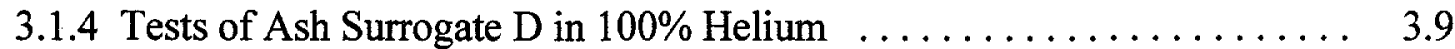

3.1.5 Isothermal Test of Ash $\mathrm{C}$ at $600^{\circ} \mathrm{C}$ in $21 \%$ Oxygen and $79 \%$ Helium $\ldots 3.10$

3.1.6 Thermogravimetric and Differential Thermal Analysis of Ash D ..... 3.10

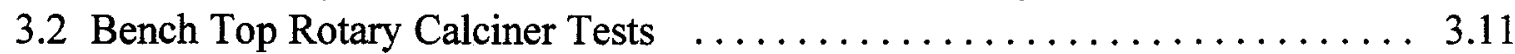

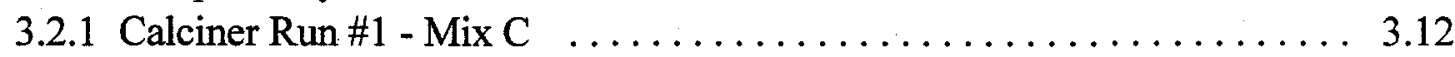

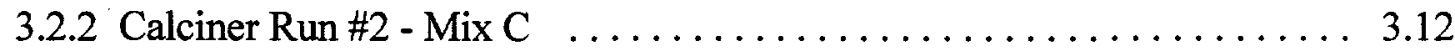

3.2.3 Calciner Run \#3a - Mix C . . . . . . . . . . . . . . . . . . . . 3.13

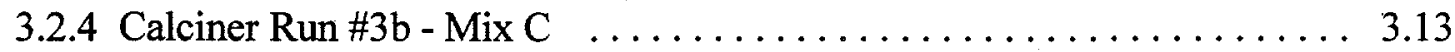

3.2.5 Calciner Run \#4-Mix C ............................... 3.14

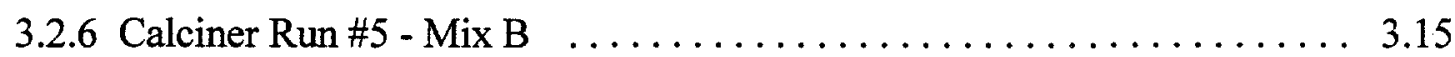

3.2.7 Calciner Run \#6 - Mix B ............................ 3.16

3.2.8 Calciner Run \#7a - U of M Ash ......................... 3.16

3.2.9 Calciner Run \#7b - U of M Ash ............................. 3.17

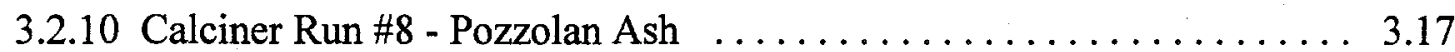

3.2.11 Calciner Run \#9 - BF Slag Ash ..................... 3.18 


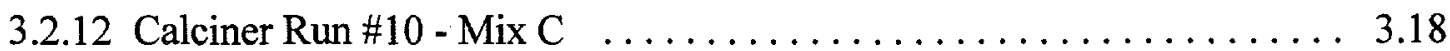

3.2.13 Calciner Run \#11 - Mix B ........................... 3.19

3.2.14 Calciner Run $\# 12$ - Mix D ............................ 3.19

3.2.15 Calciner Run \#13 - U of M Ash ..................... 3.20

3.3 Summary of Bench Top Rotary Calciner Runs $\ldots \ldots \ldots \ldots \ldots \ldots . . .21$

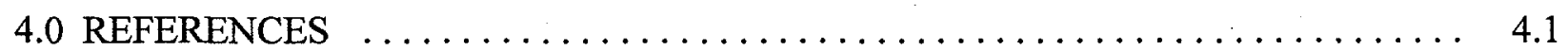

APPENDIX: RESULTS OF CALCINER RUNS $3-13 \ldots \ldots \ldots \ldots \ldots \ldots \ldots \ldots$ A.1

FIGURES

2.3 Bench Top Rotary Calciner Used for Offgas Characterization Studies $\ldots \ldots \ldots \ldots \ldots$

3.1 Calibrated GC-MS Results for Carbon in $21 \%$ Oxygen and $79 \%$ Helium $\ldots \ldots \ldots \ldots$

3.2 Calibrated GC-MS Results for Polypropylene in 21\% Oxygen and $79 \%$ Helium . . . . 3.3

3.3 Calibrated GC-MS Results for Polyvinyl Chloride in 21\% Oxygen and 79\% Helium .. 3.4

3.4 Calibrated GC-MS Results for Paper in $21 \%$ Oxygen and $79 \%$ Helium $\ldots \ldots \ldots \ldots .4$

3.5 Calibrated GC-MS Results for Ash A in 21\% Oxygen and 79\% Helium . . . . . . . 3.5

3.6 Calibrated GC-MS Results for Ash B in 21\% Oxygen and 79\% Helium $\ldots \ldots \ldots \ldots \quad 3.6$

3.7 Calibrated GC-MS Results for Ash C in 21\% Oxygen and 79\% Helium .......... 3.6

3.8 Calibrated GC-MS Results for Carbon in $100 \%$ Helium $\ldots \ldots \ldots \ldots \ldots \ldots \ldots .7$

3.9 Calibrated GC-MS Results for Paper in $100 \%$ Helium $\ldots \ldots \ldots \ldots \ldots \ldots \ldots .3 .8$

3.10 Calibrated GC-MS Results for Polyvinylchloride in $100 \%$ Helium $\ldots \ldots \ldots \ldots \ldots .3 .8$

3.11 Calibrated GC-MS Results for Ash D in $100 \%$ Helium $\ldots \ldots \ldots \ldots \ldots \ldots \ldots . .9$ 


\section{TABLES}

1.1 Rocky Flats Ash Composition Range $\ldots \ldots \ldots \ldots \ldots \ldots \ldots \ldots \ldots \ldots \ldots \ldots \ldots \ldots \ldots \ldots . .2$

2.1 Organic Products From Combustion of Polypropylene in Air . . . . . . . . . 2.2

2.2 Organic Products From Combustion of Polystyrene in Air $\ldots \ldots \ldots \ldots \ldots \ldots . .3$

2.3 Test Matrix for Quartz Crucible Furnace Studies $\ldots \ldots \ldots \ldots \ldots \ldots \ldots \ldots \ldots .2 .4$

2.4 Compositions of Ash Surrogates on an Oxide Basis $\ldots \ldots \ldots \ldots \ldots \ldots \ldots \ldots .2 .7$

3.1 Offgas Species Detected by GC-MS While Heating in Quartz Crucible $\ldots \ldots \ldots \ldots \quad 3.1$

3.2 Summary of Calcination Runs $\ldots \ldots \ldots \ldots \ldots \ldots \ldots \ldots \ldots \ldots \ldots \ldots \ldots \ldots \ldots \ldots \ldots \ldots$

3.3 Summary of Offgas Characteristics from Ash Surrogates Treated in a Bench Top

Rotary Calciner $\ldots \ldots \ldots \ldots \ldots \ldots \ldots \ldots \ldots \ldots \ldots \ldots \ldots \ldots \ldots \ldots \ldots \ldots \ldots \ldots \ldots .22$ 


\subsection{INTRODUCTION}

The Pacific Northwest National Laboratory (PNNL), in cooperation with the Los Alamos National Laboratory (LANL) and Safe Sites of Colorado (SSOC), developed a recommended flowsheet for the processing of plutonium-bearing incinerator ash stored at the Rocky Flats Environmental Technology Site (RFETS) (Luey et al. 1998). This flowsheet involves a calcination pretreatment step, the purpose of which is to remove carbonaceous material from the incinerator ash. Removal of this material reduced the probability of process upsets, improved product quality, and increases ash waste loading. As part of the continued development of the recommended flowsheet, PNNL performed a series of tests to characterize the offgas generated during the calcination process.

\subsection{Description of the Remediation Problem}

Approximately $19,700 \mathrm{~kg}$ of ash, generated by the incineration of combustibles for recovery of plutonium, are stored at RFETS. The ash must be treated for safe storage and disposal at the Waste Isolation Pilot Plant (WIPP) as transuranic waste. PNNL is responsible for developing and evaluating a vitrification process to make an agglomerated final waste form for incinerator ash. Collaborators in this process development effort included LANL and SSOC.

A simple process flowsheet for the ash consists of two main steps: mixing and thermal treatment. Ash is mixed with glass frit in appropriate proportions to maintain adequate concentrations of plutonium to permit the termination of safeguards, while ensuring that the full fissile gram equivalent (with a safety factor of twice the measurement uncertainty) is loaded in each transuranic waste drum. These batches would be loaded into stainless steel containers $(20-\mathrm{cm}$ diameter and $25-\mathrm{cm}$ tall) and thermally processed in muffle furnaces. All processes must be compatible with operation in a radioactive glovebox.

\subsection{Description of the Incinerator Ash}

Ash was generated by incinerating plutonium-bearing waste at RFETS. The furnaces were small (for criticality safety) and operated at relatively low temperatures (nominally 200 to $900^{\circ} \mathrm{C}$ ) to facilitate $\mathrm{Pu}$ recovery processes. This incineration process did not completely combust the organics. Table 1.1 shows the composition ranges reported for the RFETS incinerator ash material.(1)

(1) Long JL. "Analysis of Incinerator Ash \& Heel." Internal Rocky Flats Job Report No. PER 1-74, DPA950348, January 4, 1974. 
Table 1.1. Rocky Flats Ash Composition Range (wt\% reported as oxides, $\mathrm{C}, \mathrm{Cl}$, and $\mathrm{F}$ )

\begin{tabular}{||c|c|c|c||c|c|c|c||}
\hline & $\min$ & $\max$ & average & & $\min$ & $\max$ & average \\
\hline $\mathrm{Al}_{2} \mathrm{O}_{3}$ & 0.95 & 5.7 & 3.33 & $\mathrm{NiO}$ & 0.25 & 0.64 & 0.45 \\
\hline $\mathrm{Am}_{2} \mathrm{O}_{3}$ & 0.02 & 0.02 & 0.02 & $\mathrm{P}_{2} \mathrm{O}_{5}$ & 0.23 & 0.23 & 0.23 \\
\hline $\mathrm{B}_{2} \mathrm{O}_{3}$ & 0.32 & 3.2 & 1.76 & $\mathrm{PbO}$ & 0.58 & 0.92 & 0.75 \\
\hline $\mathrm{BaO}$ & 0.58 & 1.2 & 0.89 & $\mathrm{PuO}_{2}$ & 1.8 & 3.8 & 2.8 \\
\hline $\mathrm{CaO}$ & 1.1 & 7.0 & 4.05 & $\mathrm{SnO}$ & 0.0 & 0.25 & 0.13 \\
\hline $\mathrm{Cr}_{2} \mathrm{O}_{3}$ & 0.44 & 0.88 & 0.66 & $\mathrm{Ta}_{2} \mathrm{O}_{5}$ & 0.0 & 0.73 & 0.37 \\
\hline $\mathrm{CuO}$ & 0.63 & 1.3 & 0.97 & $\mathrm{TiO}_{2}$ & 1.0 & 1.7 & 1.35 \\
\hline $\mathrm{Fe}_{2} \mathrm{O}_{3}$ & 1.1 & 10.3 & 5.7 & $\mathrm{C}$ & 7.5 & 36.0 & 21.75 \\
\hline $\mathrm{K}_{2} \mathrm{O}$ & 0.24 & 1.2 & 0.72 & $\mathrm{SiO}_{2}$ & 14.17 & 74.10 & 48.49 \\
\hline $\mathrm{MgO} \mathrm{O} O$ & 0.83 & 8.3 & 4.57 & $\mathrm{~F}^{-}$ & 0.04 & 1.8 & 0.6 \\
\hline $\mathrm{MnO}_{2}$ & 0.03 & 0.08 & 0.06 & $\mathrm{Cl}^{-}$ & 0.8 & 6.4 & 2.7 \\
\hline $\mathrm{Na}_{2} \mathrm{O}$ & 0.0 & 2.4 & 1.2 & & & & \\
\hline \hline
\end{tabular}

The ashes are highly variable in composition, with an order of magnitude variation or more in $\mathrm{Al}_{2} \mathrm{O}_{3}, \mathrm{CaO}, \mathrm{MgO}, \mathrm{B}_{2} \mathrm{O}_{3}, \mathrm{Fe}_{2} \mathrm{O}_{3}$, and $\mathrm{C}$. The carbon/organic content is high, with a maximum of $36 \mathrm{wt} \%$ reported. Extensive analyses of the chemical and physical forms of the ashes were conducted by Behrens et al. (1995). The analyzed particles were typically 10 nanometers to $\approx 1$ micrometer in diameter. Plutonium was found as an oxide in larger glassy silicate and aluminosilicate phases.

The remainder of this report summarizes the work performed by PNNL. Section 2 describes the experimental approach used to characterize the offgas from the calcination process. Section 3 contains results from testing performed in the laboratory and in the bench top rotary calciner. 


\section{0 EXPERIMENTAL APPROACH}

Three complementary activities were performed to characterize the offgas from calcination of RFETS ash surrogates: 1) literature review, 2) laboratory studies, and 3) testing in a bench top rotary calciner. The results from the literature review provided a basis for the approaches used for laboratory and rotary calciner studies.

\subsection{Literature Review}

A literature search was performed by PNNL and focused on the pyrolysis and/or combustion of carbon (amorphous and graphite), polyvinyl chloride (PVC), polypropylene, and paper. These four carbon-containing materials were identified by SSOC as representative of carbon sources for the RFETS plutonium-bearing incinerator ash. The search identified several relevant studies of the gaseous pyrolysis products from these and closely related materials. These studies include, for example, research in the pulp and paper industry, hazardous offgassing of materials in fires, and waste incineration. Gaseous products generated during pyrolysis, combustion, and gasification under various conditions have been identified using chromatographic and spectroscopic techniques. Summarized below are some highlights from the most relevant papers identified in this literature search.

\subsubsection{Paper Pyrolysis}

The pyrolysis of cellulose was reviewed by Cullis et al. [1983], who examined the effects of (1) rapid heating rates and (2) different flow rates of inert gases. Previous work performed by these authors examined slow heating rates. It was found that slow heating rates ( 1 degree $/ \mathrm{min})$ resulted in significant dehydration and the formation of a considerable amount of solid carbonaceous material. At higher heating rates ( 60 degrees $/ \mathrm{min}$ ) very little decomposition occurred until $250^{\circ} \mathrm{C}$ to $330^{\circ} \mathrm{C}$, where significant depolymerization began, yielding tars and flammable gases.

The major products in an inert gas flow were $\mathrm{CO}$ and $\mathrm{CO}_{2}$. At temperatures below $350^{\circ} \mathrm{C}, \mathrm{CO}_{2}$ was the major product with small amounts of $\mathrm{CO}$ and even lower concentrations of methane $\left(\mathrm{CH}_{4}\right)$, ethane $\left(\mathrm{C}_{2} \mathrm{H}_{6}\right)$ and $\mathrm{H}_{2}$. However, at temperatures greater than $400^{\circ} \mathrm{C}$, CO became the major product, with increasing concentrations of the flammable hydrocarbons (although the concentration of $\mathrm{CO}_{2}$ plus $\mathrm{CO}$ was about a factor of ten times greater than that of the hydrocarbons). A table of activation parameters for predicting products is included in this reference and could provide some insight into product formation at higher temperature. 


\subsubsection{Polypropylene, Polystyrene, and Polyvinylchloride}

Smith-Hansen et al. [1992] investigated the combustion of polypropylene, polystyrene, polyvinylchloride and other materials under highly oxidizing conditions. Not surprisingly, they reported much higher ratios of $\mathrm{CO}_{2} / \mathrm{CO}$ than those identified in the Cullis work, because of the more highly oxidizing conditions. Lists of the organic offgas products identified from the combustion of polypropylene and polystyrene were included and are summarized in Tables 2.1 and 2.2. A wide variety of both alkane and aromatic hydrocarbons was formed as minor constituents during the combustion of polypropylene and polystyrene at temperatures between $500^{\circ} \mathrm{C}$ and $900^{\circ} \mathrm{C}$.

In the combustion of $\mathrm{PVC}$, the authors reported rapid dehydrochlorination to yield $\mathrm{HCl}$ at temperatures as low as $300^{\circ} \mathrm{C}$. They were able to recover $60 \%$ of the theoretical yield as $\mathrm{HCl}$, and assumed the other products were $\mathrm{Cl}_{2}$ and chlorinated hydrocarbons. Also of note was the ratio of $\mathrm{CO}_{2} / \mathrm{CO}$ obtained for the combustion of $\mathrm{PVC}$, which was determined to be relatively low compared to that determined for the combustion of polypropylene.

Table 2.1 Organic Products From Combustion of Polypropylene in Air [Smith-Hansen et al., 1992].

\begin{tabular}{|c|c|c|}
\hline Temperature & Major Compounds & Minor Compounds \\
\hline $500^{\circ} \mathrm{C}$ & none & $\begin{array}{l}\text { - alkanes }\left(>\mathrm{C}_{12}\right) \text { plus derivative } \\
\text { aldehydes and ketones }\end{array}$ \\
\hline $\begin{array}{l}700^{\circ} \mathrm{C} \text { and } \\
900^{\circ} \mathrm{C}\end{array}$ & none & $\begin{array}{l}\text { - alkanes }\left(>C_{12}\right) \text { plus derivative } \\
\text { aldehydes and ketones } \\
\text { - aromatics (e.g., biphenyl) } \\
\text { - fused ring aromatics } \\
\text { (e.g., naphthalene and pyrene) }\end{array}$ \\
\hline
\end{tabular}


Table 2.2 Organic Products From Combustion of Polystyrene in Air [Smith-Hansen et al., 1992].

\begin{tabular}{||l|c|l||}
\hline Temperature & \multicolumn{1}{|c|}{ Major Compounds } & \multicolumn{1}{c|}{ Minor Compounds } \\
\hline $500^{\circ} \mathrm{C}$ & - styrene dimers and trimers & $\begin{array}{l}\text { - aromatics } \\
\text { (e.g., 1,2-diphenylethene) }\end{array}$ \\
\hline $700^{\circ} \mathrm{C}$ & none & $\begin{array}{l}\text { - styrene dimers and trimers } \\
\text { - other aromatics } \\
\text { (e.g., 1,2-diphenylethene) } \\
\text { fused ring aromatics } \\
\text { (e.g., naphthalene and azulene) }\end{array}$ \\
\hline $900^{\circ} \mathrm{C}$ & none & $\begin{array}{l}\text { (e.g., naphthalene and azulene) } \\
\text { fused ring aromatics }\end{array}$ \\
\hline
\end{tabular}

\subsubsection{Combustion of Actual RF and Related Wastes}

Gases evolved from loss on ignition (LOI) tests of actual RFETS ashes were analyzed by Berhrens, et al. [1995]. The results of these tests indicated that the ashes exhibited a weight loss of between $6.6 \%$ and $11.3 \%$. The major offgas species detected included $\mathrm{H}_{2}, \mathrm{CO}, \mathrm{CH}_{4}, \mathrm{H}_{2} \mathrm{O}$, $\mathrm{CO}_{2}, \mathrm{O}_{2}$, and perhaps $\mathrm{SO}_{2}$. No Cl-containing phases were identified in the offgas. The $\mathrm{Cl}$ containment in the ashes was confirmed by composition analysis of ashes before and after reburning.

Thermal analysis of RFETS ash was performed at Hanford in the early 1980's [Delegard, 1984]. These tests showed a slight endotherm up to $100^{\circ} \mathrm{C}$ with a corresponding weight loss of less than $0.5 \%$. From $100^{\circ} \mathrm{C}$ to $400^{\circ} \mathrm{C}$, a slight exotherm occurred with a weight loss of $0.5 \%$. Another endotherm was seen from $400^{\circ} \mathrm{C}$ to $1000^{\circ} \mathrm{C}$, with two distinct weight loss regions. About $2.3 \%$ weight loss was recorded between $400^{\circ} \mathrm{C}$ and $600^{\circ} \mathrm{C}$ and about $5 \%$ loss between $700^{\circ} \mathrm{C}$ and $1000^{\circ} \mathrm{C}$. No weight loss was recorded between $600^{\circ} \mathrm{C}$ and $700^{\circ} \mathrm{C}$. The gas composition was not determined in these tests. The total weight loss of between 2.8 and $3.3 \%$ from room temperature to $600^{\circ} \mathrm{C}$ was measured by thermogravimetric analysis (TGA) and confirmed by large scale reburning of the ash at $600^{\circ} \mathrm{C}$ until the ash was thought to be completely reacted. The further weight loss between $700^{\circ} \mathrm{C}$ and $1000^{\circ} \mathrm{C}$ is thus caused by a different, high temperature, reaction. Three different ashes were tested with loss on ignition (LOI) values of $23.1,9.3$, and $2.6 \%$. 
The combustion of low level waste at the DOE Mound facility was reviewed in a report by Bond et al [1978]. The work is very relevant because the composition of waste examined (32 wt\% paper, $46 \%$ plastic, $16 \%$ rubber and cloth and $6 \%$ metal with traces of $\mathrm{Pu}-238$ ) is comparable to that of the Rocky Flats ash. The Mound waste was burned in a cyclone burner and the offgas scrubbed and passed through a HEPA filter. The treated offgas contained approximately 9.0 $\mathrm{wt} \% \mathrm{CO}_{2}, 13.5 \mathrm{wt} \% \mathrm{O}_{2}, 11.0 \mathrm{wt} \% \mathrm{H}_{2} \mathrm{O}, 10-600 \mathrm{ppm} \mathrm{NO} \mathrm{N}_{\mathrm{x}}, 1-13 \mathrm{ppm} \mathrm{HCl}$, and the balance $\mathrm{N}_{2}$. Most of the $\mathrm{HCl}$ was trapped in the scrubber solution. No mention of flammable offgas components was included in the report.

\subsection{Quartz Crucible Studies}

A series of ash surrogates and combustible materials were studied using the quartz crucible furnace for heat treatment. Table 2.3 shows the matrix of materials and atmospheres tested. The four ashes $\mathrm{A}, \mathrm{B}, \mathrm{C}$, and $\mathrm{D}$ are described further in the following section. Alumina $\left(\mathrm{Al}_{2} \mathrm{O}_{3}\right)$ was added to the first four materials to provide hot surfaces to promote the solid/gas reactions. Alumina was not needed for the ash surrogates because of the presence of non-reacting compounds in the surrogates that act as hot surfaces. The quartz crucible furnace, shown in Figure 2.1, is designed to operate with transparent fused silica (quartz) crucibles that allow examination of the sample during processing. A high-resolution camera views the transparent crucible through a quartz window in the furnace door.

Table 2.3 Test Matrix for Quartz Crucible Furnace Studies

\begin{tabular}{||l|c|c||}
\hline \multicolumn{1}{|c|}{ Sample Material } & $100 \%$ Helium & $21 \%$ Oxygen/79\% Helium \\
\hline Carbon $/ \mathrm{Al}_{2} \mathrm{O}_{3}$ & $\mathrm{X}$ & $\mathrm{X}$ \\
\hline Polypropylene $/ \mathrm{Al}_{2} \mathrm{O}_{3}$ & $\mathrm{X}$ & $\mathrm{X}$ \\
\hline Polyvinylchloride $/ \mathrm{Al}_{2} \mathrm{O}_{3}$ & $\mathrm{X}$ & $\mathrm{X}$ \\
\hline Paper $/ \mathrm{Al}_{2} \mathrm{O}_{3}$ & $\mathrm{X}$ & $\mathrm{X}$ \\
\hline Ash A & & $\mathrm{X}$ \\
\hline Ash $\mathrm{B}$ & & $\mathrm{X}$ \\
\hline Ash C & & $\mathrm{X}$ \\
\hline Ash D & $\mathrm{X}$ & \\
\hline
\end{tabular}




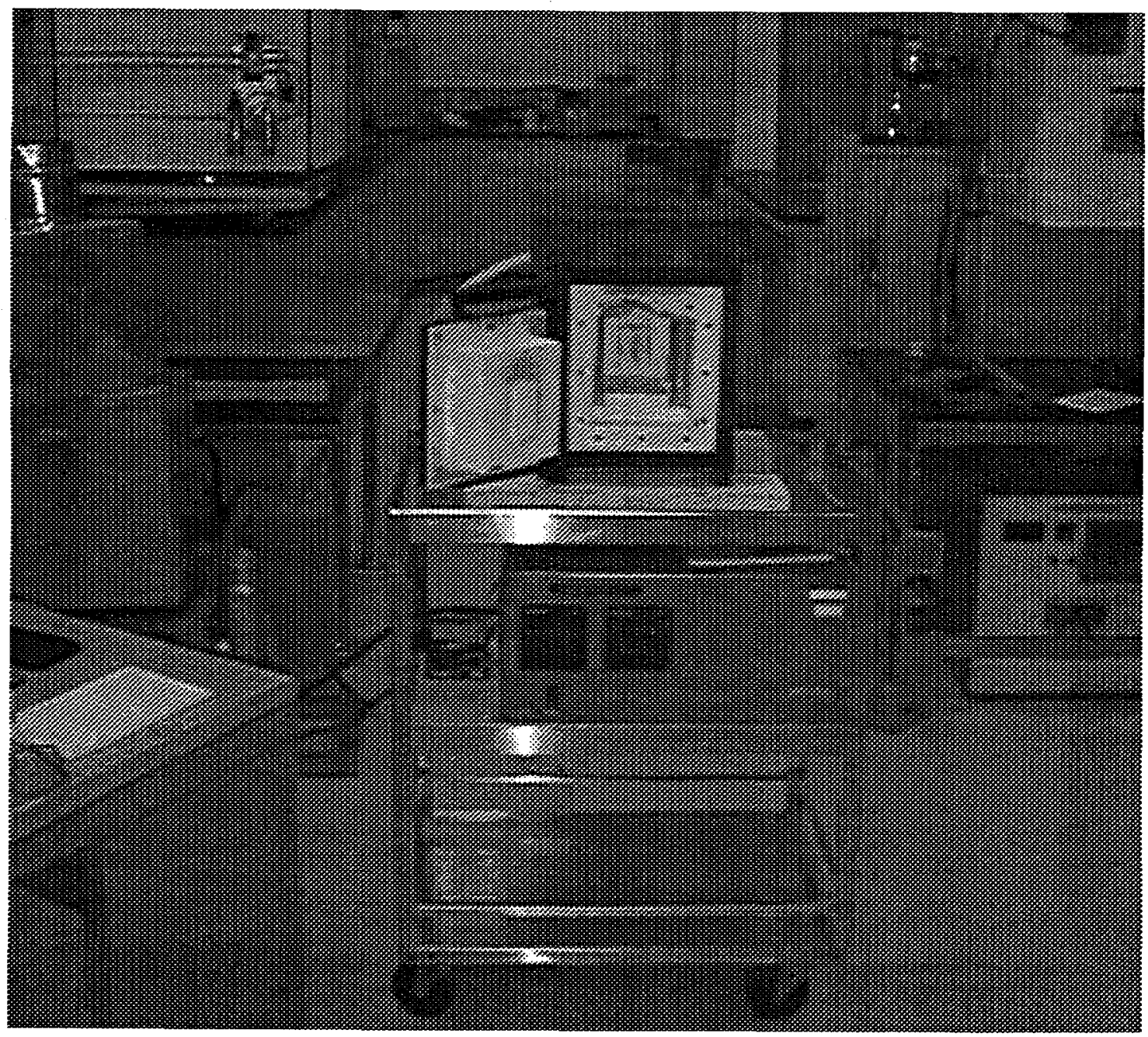

Figure 2.1 Quartz Crucible Furnace

The crucible is placed into the furnace and sealed, and pre-mixed gases $(100 \% \mathrm{He}$ or a mixture of $21 \% \mathrm{O}_{2} / 79 \% \mathrm{He}$ ) are swept over the sample to control the reaction atmosphere. Figure 2.2 illustrates the system used to measure offgas from a sample. Temperature measurements are made using a certified thermocouple touching the crucible in the furnace hot zone. The typical heating rate for these studies was $5^{\circ} \mathrm{C} / \mathrm{min}$. The gases generated from the sample are mixed into the sweep gas and measured using an in-line gas chromatograph/mass spectrometer system (Smith, Vienna, and Hrma 1995). Gas compositions are quantified with calibration factors generated by passing certified standard gases through the offgas measurement systems. Standard gases used in this study include carbon monoxide, carbon dioxide, hydrogen, oxygen, and methane. Analyses of all other gases are semiquantitative. 


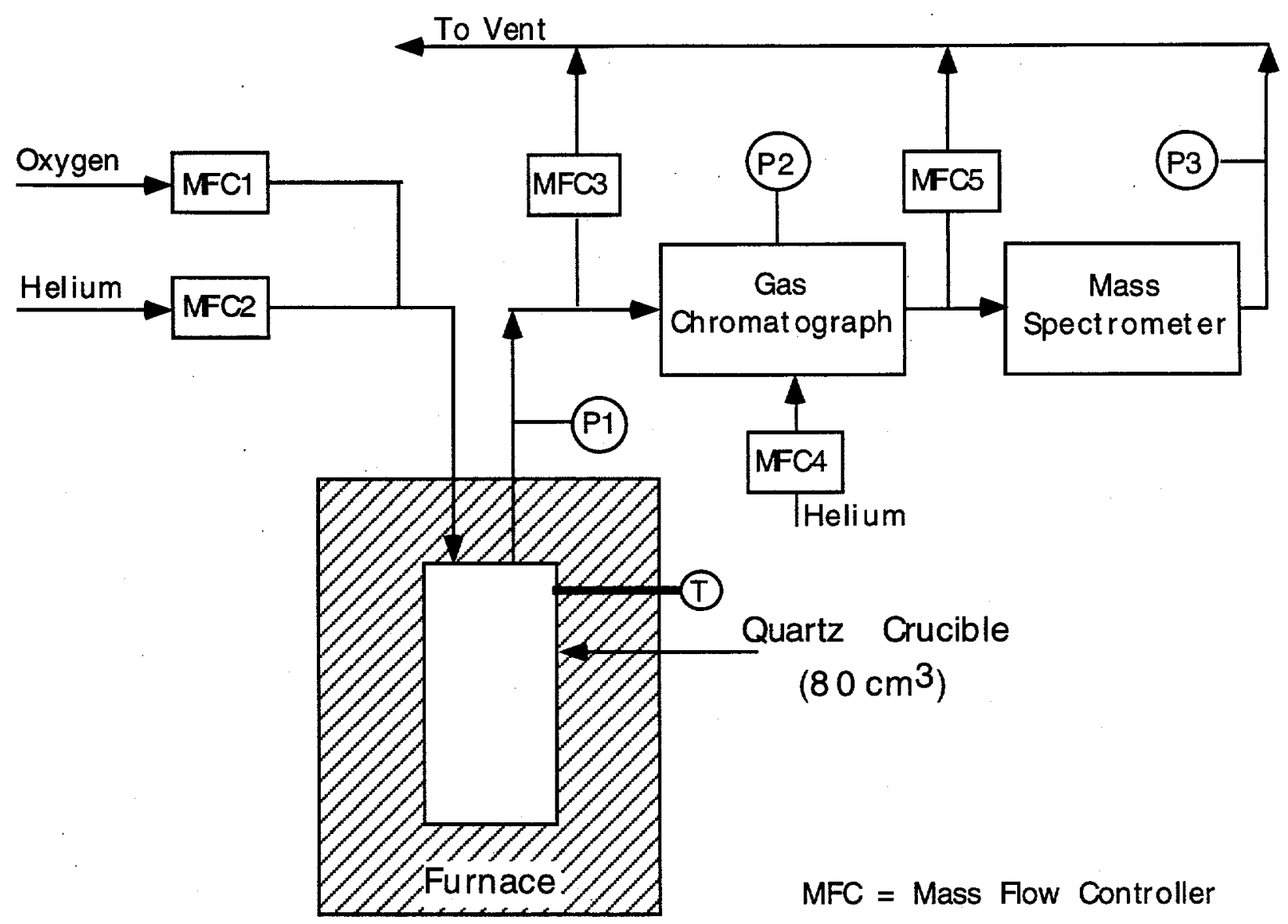

Figure 2.2 Configuration for Measuring Offgas Composition from Quartz Crucible

\subsection{Rotary Calciner Studies}

The six ash surrogates selected for testing in the rotary calciner were the same ones used to develop the recommended flowsheet for the vitrification process in fiscal year 1997: U of M Ash, Pozzolan Ash, BF Slag Ash, RFETS Mix B, RFETS Mix C, and RFETS Mix D. The U of $M$ Ash was generated from a medical incinerator which processed material from the University of Maryland, both the Pozzolan and BF Slag ashes are from commercial incinerators, and the RFETS ashes were all prepared by the Colorado Minerals Research Institute. Table 2.4 shows the weight percent composition of the surrogates on a metal oxide basis and compares the surrogates to the minimum and maximum values reported for the RFETS incinerator ash. Pozzolan ash was used instead of RFETS Mix A to represent the $5 \mathrm{wt} \%$ carbon material because it was generated from an incineration process, while the RFETS surrogate was not. 
Table 2.4 Compositions of Ash Surrogates on an Oxide Basis

\begin{tabular}{|c|c|c|c|c|c|c|c|c|}
\hline & $U$ of $M$ & Pozzolan & BF Slag & RFETS & Ash & Mixes & RFETS & Actual \\
\hline & & ash & ash & B & C & D & Min & Max \\
\hline $\mathrm{SiO}_{2}$ & 29.48 & 48.53 & 37.87 & 14.99 & 43.49 & 14.15 & 14.17 & 48.49 \\
\hline $\mathrm{B}_{2} \mathrm{O}_{3}$ & 2.39 & & & 2.77 & 1.83 & 3.27 & 0.32 & 1.76 \\
\hline $\mathrm{Na}_{2} \mathrm{O}$ & 2.83 & 3.52 & 0.25 & 1.22 & 0.59 & 1.44 & 0.00 & 1.20 \\
\hline $\mathrm{CaO}$ & 16.29 & 8.92 & 34.75 & 5.99 & 4.92 & 5.66 & 1.1 & 4.05 \\
\hline $\mathrm{MgO}$ & 2.17 & 2.99 & 18.35 & 5.99 & 4.83 & 5.66 & 0.83 & 4.57 \\
\hline $\mathrm{Fe}_{2} \mathrm{O}_{3}$ & 1.87 & 5.05 & 0.25 & 7.99 & 6.28 & 7.55 & 1.1 & 5.70 \\
\hline $\mathrm{Al}_{2} \mathrm{O}_{3}$ & 12.74 & 23.77 & 5.38 & 5.00 & 4.35 & 4.72 & 0.95 & 3.33 \\
\hline $\mathrm{ZrO}_{2}$ & & 0.14 & 0.04 & & - & & & \\
\hline $\mathrm{C}$ & 9.65 & 5.13 & & 39.96 & 21.75 & 37.74 & 7.5 & 21.75 \\
\hline Plastic & & & & & 2.42 & 4.72 & & \\
\hline Paper & & & & & 0.48 & 0.94 & & \\
\hline $\mathrm{CeO}_{2}$ & & & & 14.99 & 8.21 & 14.15 & & \\
\hline $\mathrm{BaO}$ & 0.39 & & & & & & 0.58 & 0.89 \\
\hline $\mathrm{Cl}$ & 1.06 & & & 0.47 & 0.23 & & 0.8 & 2.70 \\
\hline $\mathrm{Cr}_{2} \mathrm{O}_{3}$ & 0.05 & & & & & & 0.44 & 0.66 \\
\hline $\mathrm{CuO}$ & & & & & & & 0.63 & 0.97 \\
\hline $\mathrm{F}$ & & & & & 0.94 & & & \\
\hline $\mathrm{K}_{2} \mathrm{O}$ & 1.83 & 0.58 & 0.35 & 0.64 & 0.31 & & 0.24 & 0.72 \\
\hline $\mathrm{MnO}$ & 0.05 & 0.04 & 0.45 & & & & 0.03 & 0.06 \\
\hline $\mathrm{NiO}$ & & & & & & & 0.25 & 0.45 \\
\hline $\mathrm{P}_{2} \mathrm{O}_{5}$ & 11.01 & 0.60 & & & & & 0.23 & 0.23 \\
\hline $\mathrm{PbO}$ & 0.48 & & & & & & 0.58 & 0.75 \\
\hline $\mathrm{SO}_{3}$ & 1.92 & 0.58 & 2.25 & & & & & \\
\hline $\mathrm{SrO}$ & & 0.17 & 0.04 & & & & & \\
\hline $\mathrm{SnO}$ & 0.40 & & & & & & 0.0 & 0.13 \\
\hline $\mathrm{TiO}_{2}$ & 3.75 & & & & & & 1.0 & 1.35 \\
\hline $\mathrm{ZnO}$ & 1.63 & & & & & & & \\
\hline
\end{tabular}


Testing was performed in a bench top rotary calciner manufactured by Quinn Processing Equipment (Denver, Colorado). The main system components are a cylindrical furnace (split in half and hinged), power supply controlled by temperature setpoint, drive mechanism to rotate the calcining tube, and the calciner inner tube itself (both quartz and stainless steel). Figure 2.3 illustrates the calciner system (minus the power supply), with a stainless steel inner tube configured for the injection of gases and offgas monitoring. Except for the first three calciner runs performed with a quartz inner tube, all of the runs were performed using a stainless steel inner tube.

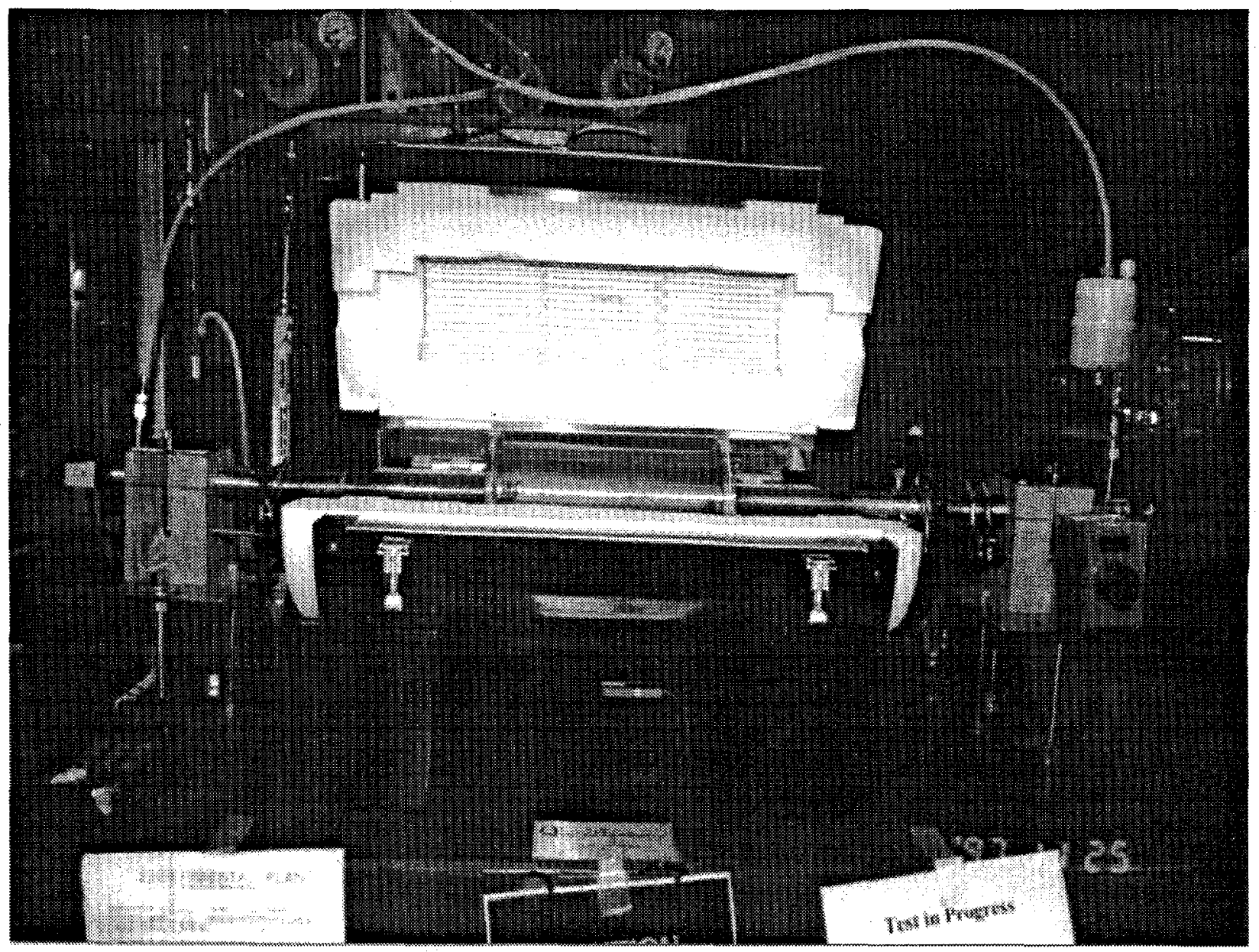

Figure 2.3 Bench Top Rotary Calciner Used for Offgas Characterization Studies 
A processing temperature of $700^{\circ} \mathrm{C}$ was selected for the calcination step based on work performed in fiscal year 1997 and limited laboratory testing in fiscal year 1998 (Luey et al. 1998). These studies showed that a temperature of $700^{\circ} \mathrm{C}$ was sufficient to calcine an ash and remove the theoretical amount of carbonaceous material from the ash surrogates. With $700^{\circ} \mathrm{C}$ as a reference, small-scale tests were performed in 1998 to see if there was a benefit in processing time and performance from a calcination temperature of $825^{\circ} \mathrm{C}$. These tests showed that there was not any benefit and actually some potential disadvantages from material clumping at the higher processing temperature.

Figure 2.4 illustrates the configuration used to measure the offgas generated during the calcination process. The bench top rotary calciner was configured to allow for the injection of variable mixtures of air and pure oxygen. As discussed in the following section, pure oxygen was injected when it was observed that the system was oxygen deficient during operation. Helium was also injected at a known flow rate (about $6 \mathrm{sccm}$ ) and was used as a tracer to quantify the amount of different gases generated during the calcination process. Calibrated mass flow controllers were used to introduce gas into the calciner. As an operator aid, calibration curves were developed relating the flow rate in standard cubic centimeters per minute to the counts displayed.

A Microsensor Technology Incorporated gas chromatograph (GC) (Model M200D) was used to measure the composition of the gases generated. Two columns are used in the GC to measure helium, hydrogen, carbon monoxide, carbon dioxide, methane, oxygen, and nitrogen. One column is a molecular sieve $(5 \AA)$ and the other is a Poraplot $U$. The cycle time for the acquisition and analysis of an in-line sample was between one and two minutes.

To minimize the potential for the carryover of particulate, steel wool was inserted into the ends of the calciner tube. This was felt necessary because of the nature of the ash surrogates (some of them very fine) and the less than optimal design of the calciner (the direct line of sight from the gas inlet to the outlet is well suited for material carryover). A filter on the outlet of the calciner was used to ensure that particulate matter that which got past the steel wool did not enter the offgas detection system. 


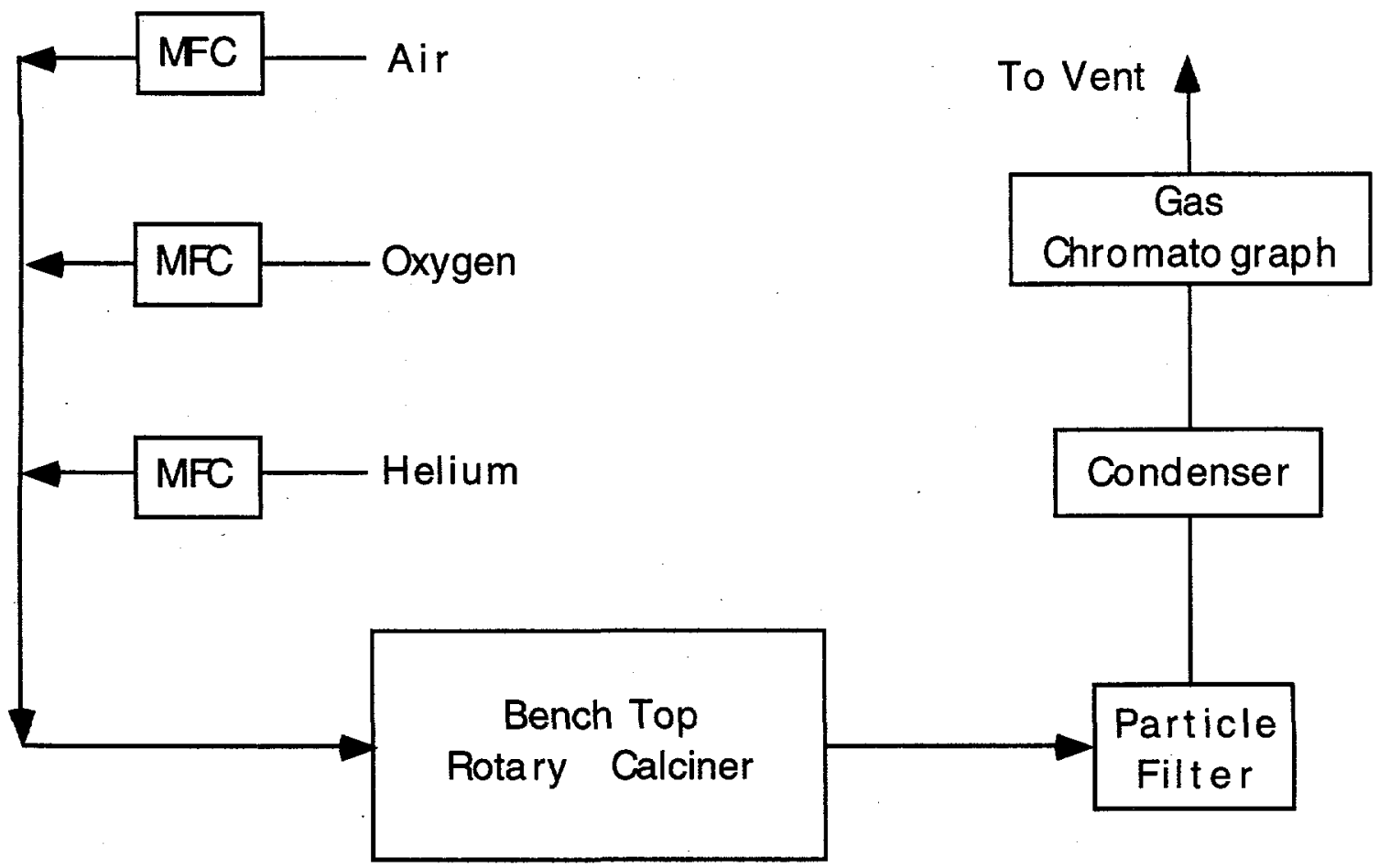

Figure 2.4 Configuration for Measuring Offgas During Calcination Process 


\subsection{RESULTS AND DISCUSSION}

\subsection{Quartz Crucible Measurements}

Both qualitative and semi-quantitative results were obtained from the tests in the quartz crucible. All of the identified gases detected by GC-MS for each of the runs are listed in Table 3.1.

Unidentified compounds (i.e., compounds yielding MS peaks which could not be unambiguously assigned) are not included in the table. Gases which were analyzed semi-quantitatively using calibration runs with appropriate gases of known concentrations included $\mathrm{CO}_{2}, \mathrm{CO}$, methane $\left(\mathrm{CH}_{4}\right)$, and $\mathrm{H}_{2}$. Additional gases, such as $\mathrm{H}_{2} \mathrm{O}, \mathrm{HCl}$, ethane $\left(\mathrm{C}_{2} \mathrm{H}_{6}\right)$, and propane $\left(\mathrm{C}_{3} \mathrm{H}_{8}\right)$, were also detected by GC-MS but were not quantified due to a lack of appropriate standards. These results are summarized qualitatively in Table 3:1.

Table 3.1 Offgas Species Detected by GC-MS While Heating in Quartz Crucible

\begin{tabular}{||l|l|c|c|c|c|c|c|c|c||}
\hline \multicolumn{19}{|c|}{ Offgas species identified } \\
\hline Feed & Atm. & $\mathrm{CO}_{2}$ & $\mathrm{CO}$ & $\mathrm{H}_{2} \mathrm{O}$ & $\mathrm{HCl}$ & $\mathrm{H}_{2}$ & $\mathrm{CH}_{4}$ & $\mathrm{C}_{2} \mathrm{H}_{6}$ & $\mathrm{C}_{3} \mathrm{H}_{8}$ \\
\hline Carbon $/ \mathrm{Al}_{2} \mathrm{O}_{3}$ & $21 \% \mathrm{O}_{2}$ & + & + & + & - & - & - & - & - \\
\hline $\mathrm{PP} / \mathrm{Al}_{2} \mathrm{O}_{3}$ & $21 \% \mathrm{O}_{2}$ & + & + & + & - & + & + & + & + \\
\hline $\mathrm{PVC} / \mathrm{Al}_{2} \mathrm{O}_{3}$ & $21 \% \mathrm{O}_{2}$ & + & + & + & + & + & + & + & + \\
\hline $\mathrm{Paper} / \mathrm{Al}_{2} \mathrm{O}_{3}$ & $21 \% \mathrm{O}_{2}$ & + & + & + & - & + & + & $*$ & $*$ \\
\hline Ash $\mathrm{A}$ & $21 \% \mathrm{O}_{2}$ & + & + & + & - & - & - & - & - \\
\hline Ash B & $21 \% \mathrm{O}_{2}$ & + & + & + & - & - & - & - & - \\
\hline Ash C & $21 \% \mathrm{O}_{2}$ & + & + & + & - & - & - & - & - \\
\hline $\mathrm{Carbon} / \mathrm{Al}_{2} \mathrm{O}_{3}$ & $\mathrm{He}$ & + & + & + & - & - & - & - & - \\
\hline $\mathrm{PP} / \mathrm{Al}_{2} \mathrm{O}_{3}$ & $\mathrm{He}$ & + & + & + & - & - & + & + & + \\
\hline $\mathrm{PVC} / \mathrm{Al}_{2} \mathrm{O}_{3}$ & $\mathrm{He}$ & + & + & + & + & + & + & + & + \\
\hline $\mathrm{Paper} / \mathrm{Al}_{2} \mathrm{O}_{3}$ & $\mathrm{He}$ & + & + & + & - & - & + & $*$ & $*$ \\
\hline Ash D & $\mathrm{He}$ & + & + & $*$ & - & - & + & + & + \\
\hline
\end{tabular}

$\mathrm{PP}=$ polypropylene, $\mathrm{PVC}=$ polyvinylchloride,$+=$ species identified in offgas, $-=$ species not identified in offgas, $*=$ trace or questionable identification of species in offgas. 
Still other gases which were examined semi-quantitatively but are not summarized in the results included $\mathrm{NO}_{\mathrm{x}}$ species and ammonia. These species were rarely encountered and were at extremely low concentrations when they were detected. Their presence was presumably due to slight system gas leaks, and not to any reactions that might be occurring within the ash simulants and reference compounds.

\subsubsection{Tests of Carbon Components in Oxygen and Helium}

The calibrated GC-MS results obtained from heating carbon $/ \mathrm{Al}_{2} \mathrm{O}_{3}$, polypropylene ( $\left.\mathrm{PP}\right) / \mathrm{Al}_{2} \mathrm{O}_{3}$, polyvinylchloride ( $\mathrm{PVC}$ ) $/ \mathrm{Al}_{2} \mathrm{O}_{3}$, and paper $/ \mathrm{Al}_{2} \mathrm{O}_{3}$ in $21 \% \mathrm{O}_{2}$ and $79 \%$ helium at $5^{\circ} \mathrm{C} / \mathrm{min}$ to $1000^{\circ} \mathrm{C}$ are presented in Figures 3.1 to 3.4. In the offgas collected from carbon, note the nearly continuous increase in $\mathrm{CO}_{2}$ concentration with temperature, beginning at about $90^{\circ} \mathrm{C}$; and the relatively high $\mathrm{CO}_{2} / \mathrm{CO}$ ratio at all temperatures. In contrast, $\mathrm{PP}, \mathrm{PVC}$, and paper show significant variations in the offgas concentrations of $\mathrm{CO}_{2}$ and $\mathrm{CO}$ as well as in the $\mathrm{CO}_{2} / \mathrm{CO}$ ratio with temperature.

The offgas from PP, PVC, and paper heated in this oxidizing environment also contained significant concentrations of methane and $\mathrm{H}_{2}$. In addition, $\mathrm{MS}$ peaks corresponding to mass units of $15,26,27,28,29,30,39,43$, and 44 were obtained at different GC retention times, indicating that ethane and propane may also be present in the offgas from PP and PVC. The generation of methane, ethane, and propane paralleled each other, with maximum offgas concentrations occurring between approximately $450^{\circ} \mathrm{C}$ and $500^{\circ} \mathrm{C}$. These results are consistent with results obtained by Smith-Hansen et al. [1992] and indicate that alkanes are evolved during the heating of PP under oxidizing conditions, although the larger molecular weight alkanes $(>\mathrm{C} 12)$ identified in the literature were not specifically detected in our experiments.

Not indicated on the plot shown in Figure 3.3, due to a lack of suitable calibration standards and it failure to elute properly from the $\mathrm{GC}$ column, is the presence of $\mathrm{HCl}$ detected in the offgas obtained from PVC. Generation of $\mathrm{HCl}$ was short-lived, with a maximum concentration occurring at $\approx 330^{\circ} \mathrm{C}$. This is consistent with the literature results [Smith-Hansen et al., 1992], in which rapid dehydrochlorination to yield $\mathrm{HCl}$ was observed at temperatures as low as $300^{\circ} \mathrm{C}$.

PVC and paper heated under these oxidizing conditions both yielded unidentified organic products which condensed in the tubes and fittings of the experimental apparatus as tar-like substances, which are most likely higher molecular weight alkanes and perhaps aromatic compounds. 


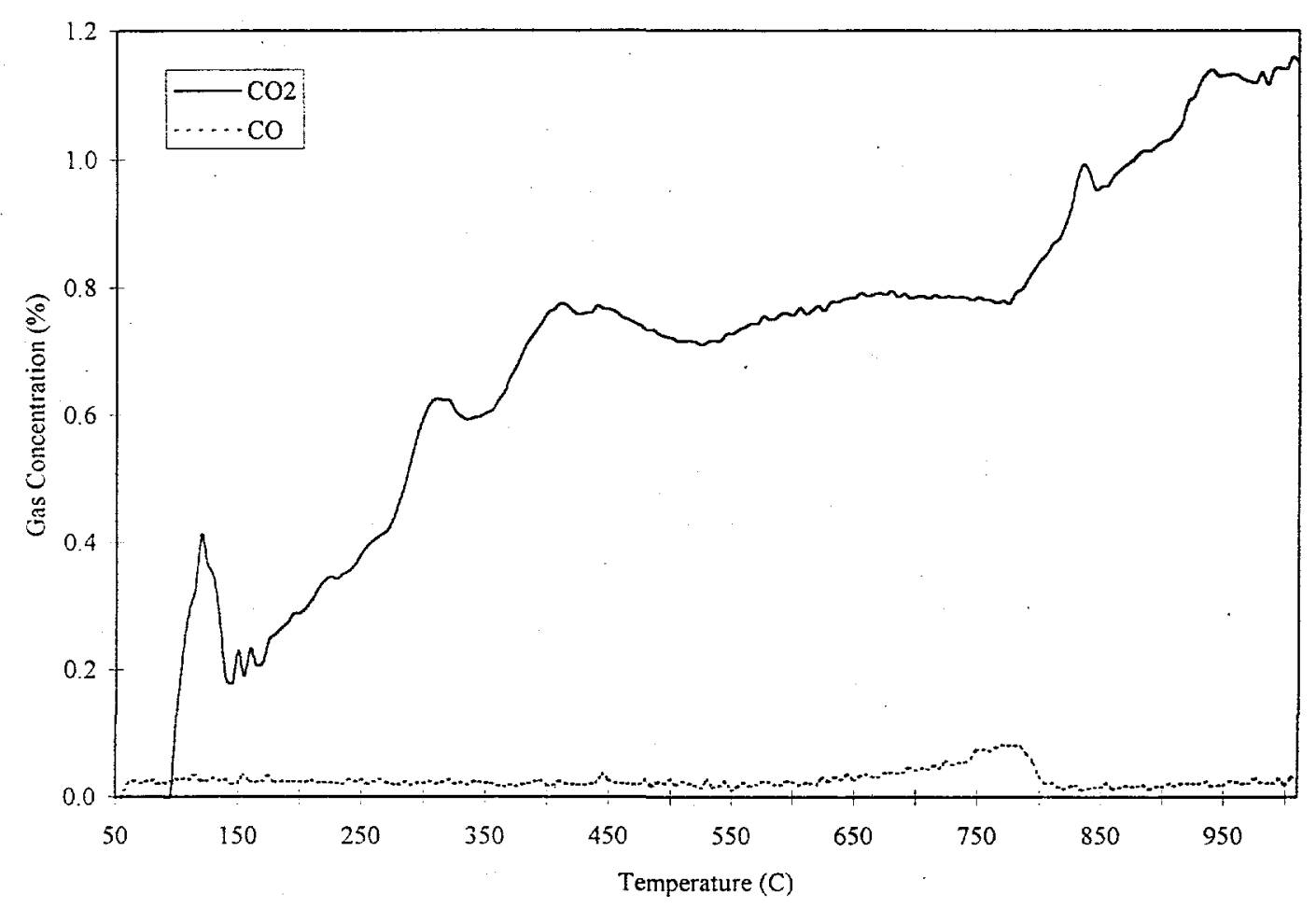

Figure 3.1 Calibrated GC-MS Results for Carbon in 21\% Oxygen and $79 \%$ Helium

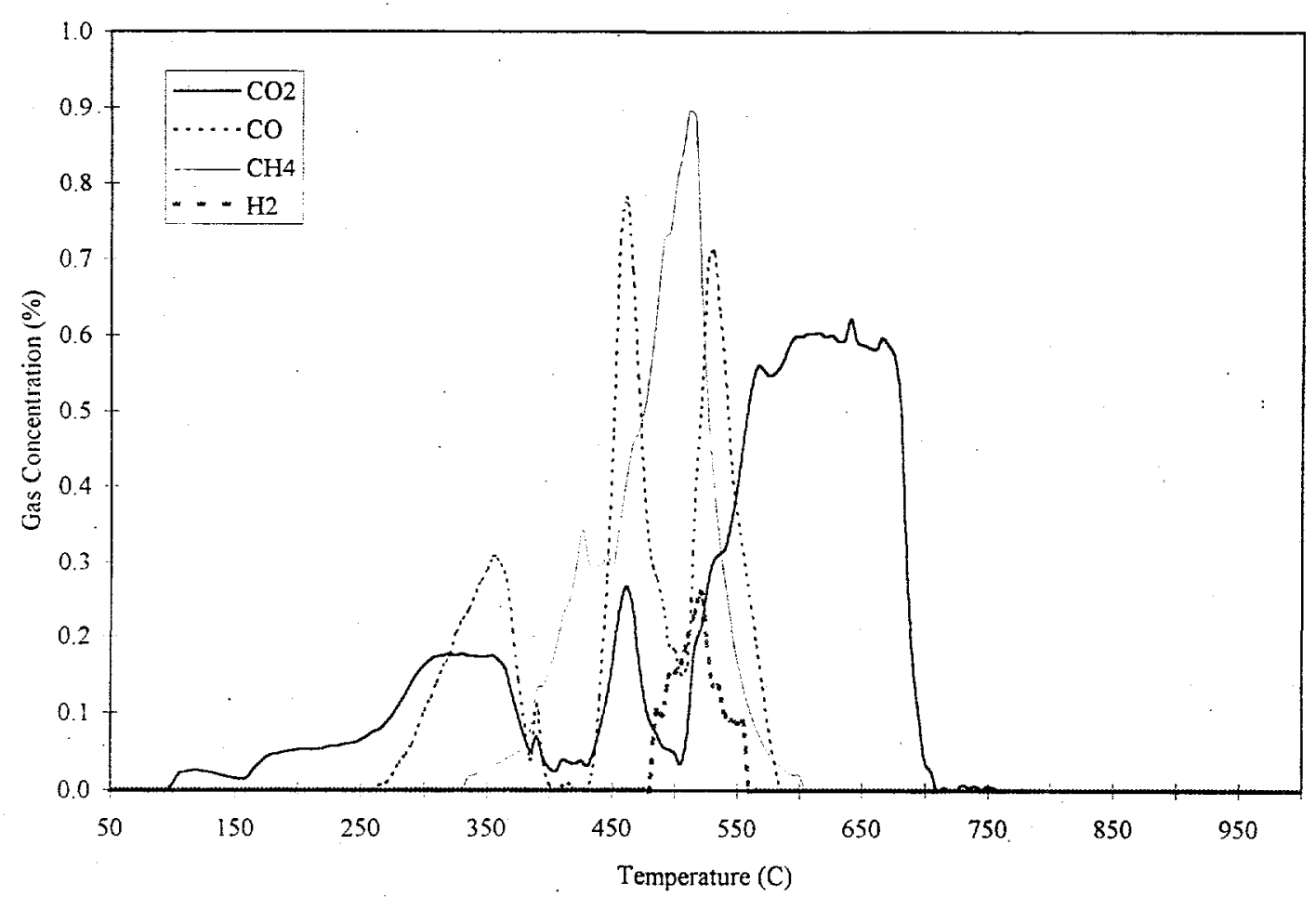

Figure 3.2 Calibrated GC-MS Results for Polypropylene in 21\% Oxygen and 79\% Helium 


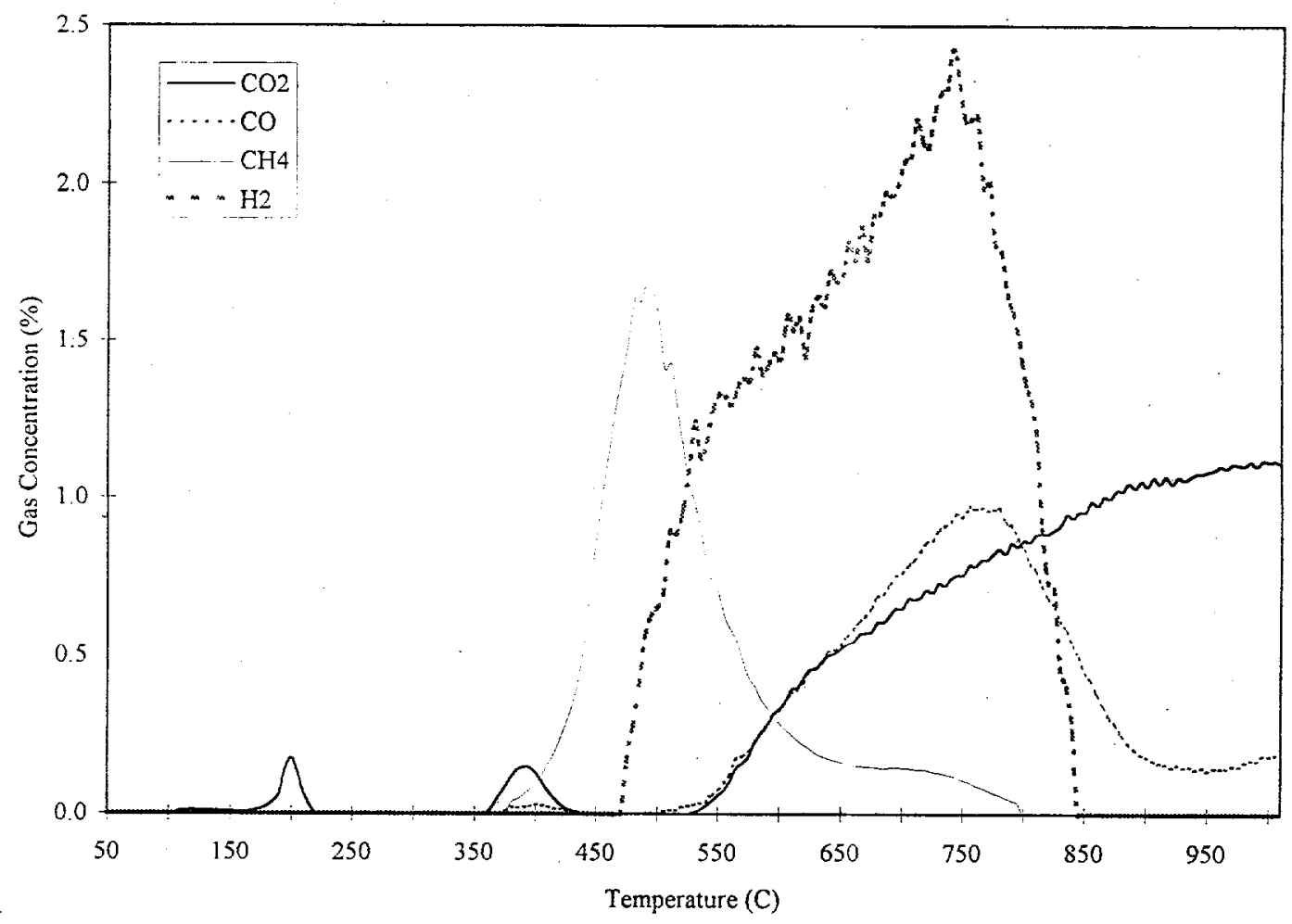

Figure 3.3 Calibrated GC-MS Results for Polyvinyl Chloride in 21\% Oxygen and 79\% Helium

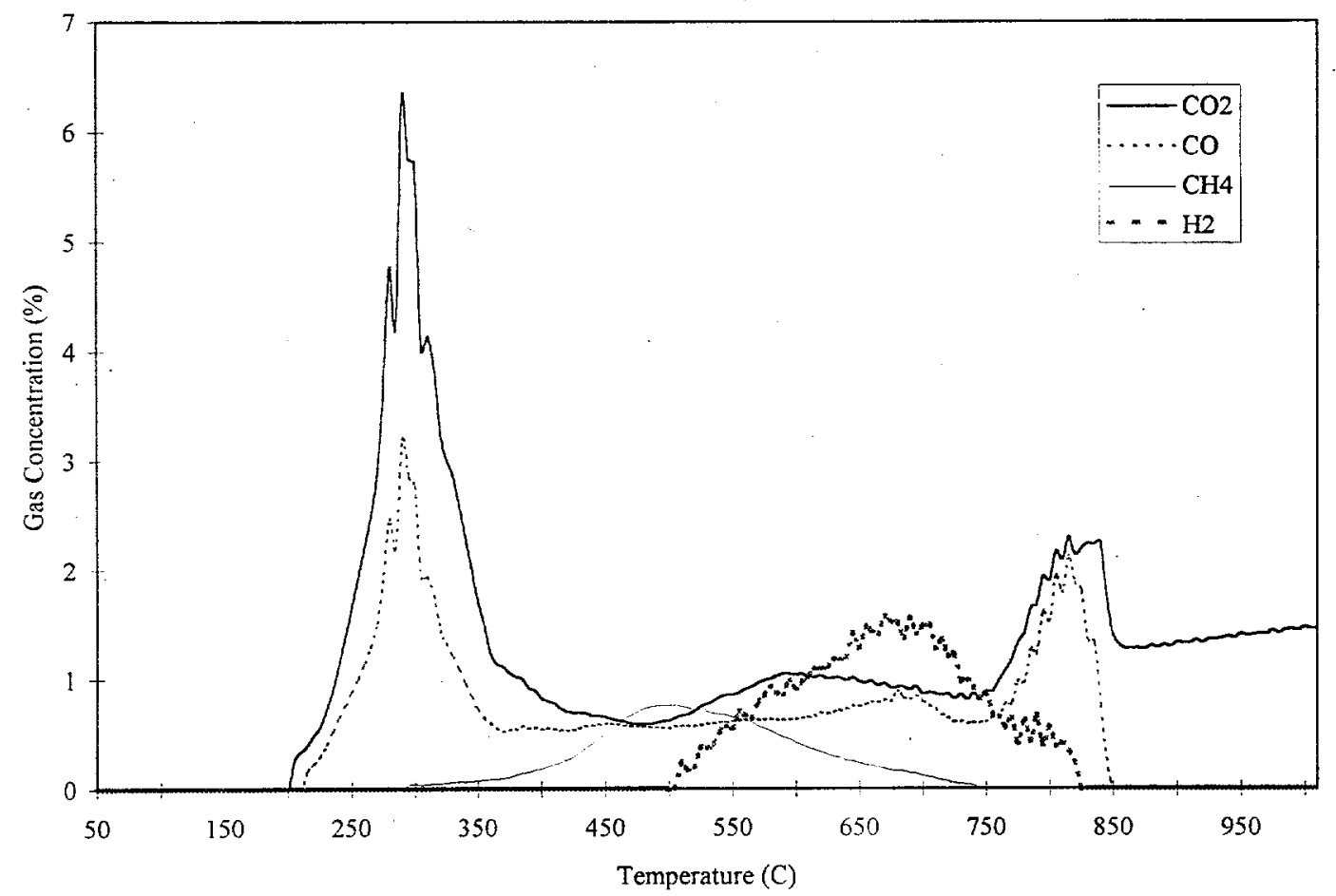

Figure 3.4 Calibrated GC-MS Results for Paper in 21\% Oxygen and 79\% Helium 


\subsubsection{Tests of Ash Surrogates in Oxygen and Helium}

Figures 3.5 to 3.7 show calibrated GC-MS results obtained from heating ash simulants $\mathrm{A}, \mathrm{B}$, and $\mathrm{C}$ in $21 \% \mathrm{O}_{2}$ and $79 \%$ helium at $5^{\circ} \mathrm{C} / \mathrm{min}$ to $1000^{\circ} \mathrm{C}$. Note that in all cases the only major species present (other than water) in the offgas were $\mathrm{CO}_{2}$ and $\mathrm{CO}$ and that the $\mathrm{CO}$ peak offgas temperatures appeared to be dependent on the ash simulant. The carbon-containing sources in ash simulants $\mathrm{A}$ and $\mathrm{B}$ were derived only from carbon, so their rough similarities to the offgas characteristics of carbon alone (see Figure 3.1) were not too surprising.

Ash surrogate $\mathrm{C}$, however, also contained $\mathrm{PP}, \mathrm{PVC}$, and paper, which were previously shown to generate $\mathrm{H}_{2}$, methane, ethane, and propane when heated in oxidizing environments. The lack of any significant $\mathrm{H}_{2}$, methane, ethane, and propane generation in Ash $\mathrm{C}$ under the same conditions is noteworthy, and is most likely due to the particular combination and concentrations of mineral/glass phases and organics/carbon found in Ash C.

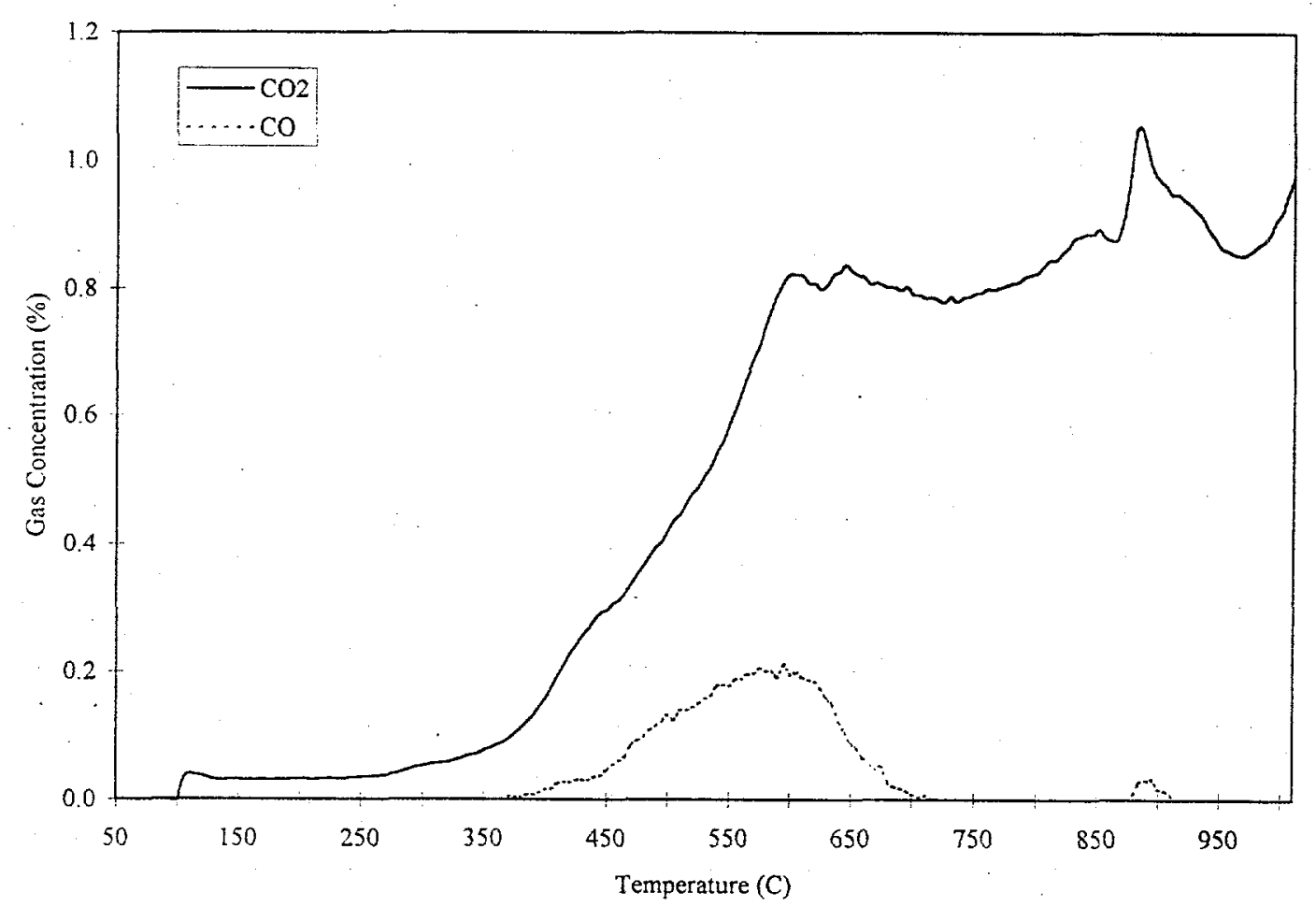

Figure 3.5 Calibrated GC-MS Results for Ash A in 21\% Oxygen and 79\% Helium 


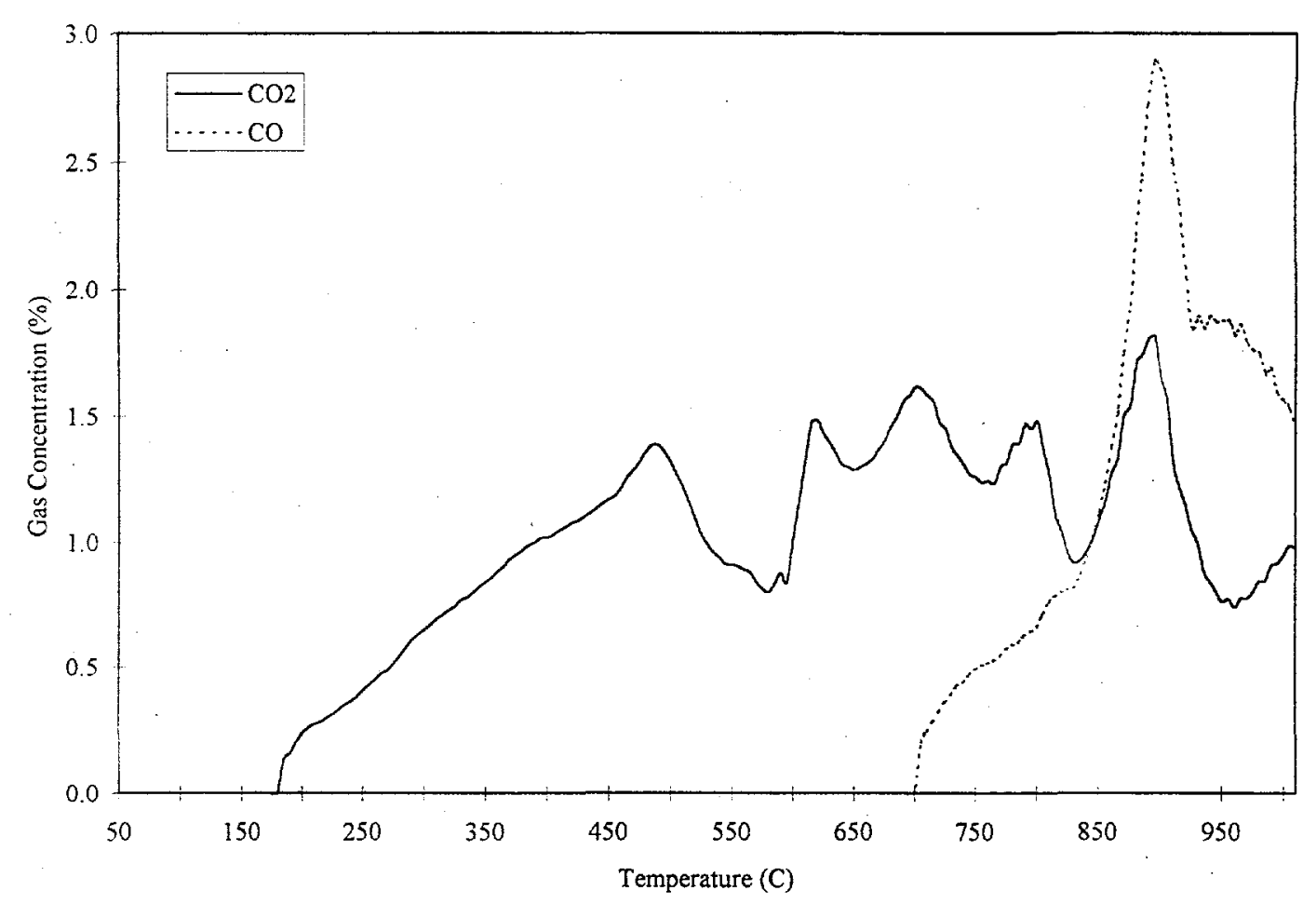

Figure 3.6 Calibrated GC-MS Results for Ash B in 21\% Oxygen and 79\% Helium

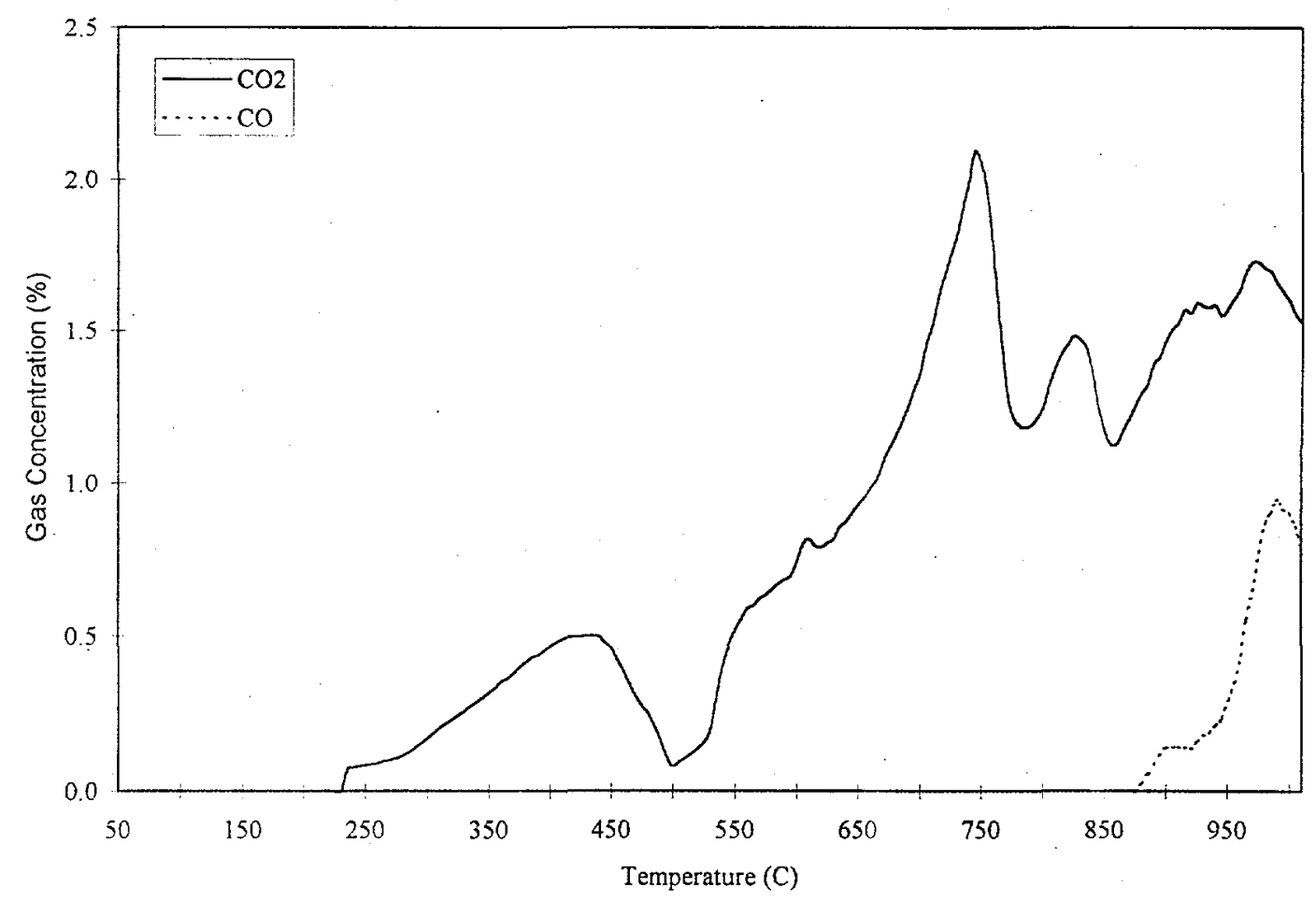

Figure 3.7 Calibrated GC-MS Results for Ash C in 21\% Oxygen and 79\% Helium 


\subsubsection{Tests of Carbon Components in $100 \%$ Helium}

The calibrated GC-MS results obtained from heating carbon, paper, and PVC in $\mathrm{He}$ at $5^{\circ} \mathrm{C} / \mathrm{min}$ to $1000^{\circ} \mathrm{C}$ are presented in Figures 3.8 to 3.10. Note that very little offgas product, which was observed to be mainly $\mathrm{CO}_{2}$ and $\mathrm{CO}$, was generated from carbon under these conditions. In general, paper and PVC also yielded significantly lower concentrations of offgas products under these conditions, compared to similar heating experiments conducted in $21 \%$ oxygen (see Figures 3.3 and 3.4). In the offgas collected from paper heated in $100 \%$ helium (see Figure 3.9), $\mathrm{CO}_{2}$, $\mathrm{CO}$, and methane were the major species identified, which is consistent with the results in Cullis et al. (1983).

As was the case for oxidizing conditions, PVC and paper heated under an inert ( $\mathrm{He}$ ) environment also yielded organic products which condensed in the experimental apparatus as tar-like substances. With this caveat, the results obtained for paper and PVC are presented in Figures 3.9 3.10. Note that the production of tar during heating under inert conditions was accompanied by a relatively low concentration of the offgas species $\mathrm{CO}_{2}, \mathrm{CO}$, and methane, as well as ethane and propane; but a relatively high concentration of $\mathrm{H}_{2}$ above $550^{\circ} \mathrm{C}$. Hydrogen chloride was also identified in the offgas obtained from PVC, with a maximum concentration occurring at $\approx 360^{\circ} \mathrm{C}$. Similar to the results obtained under oxidizing conditions, the maximum offgas concentrations of methane, ethane, and propane produced from PVC and paper occurred between 450 and $500^{\circ} \mathrm{C}$.

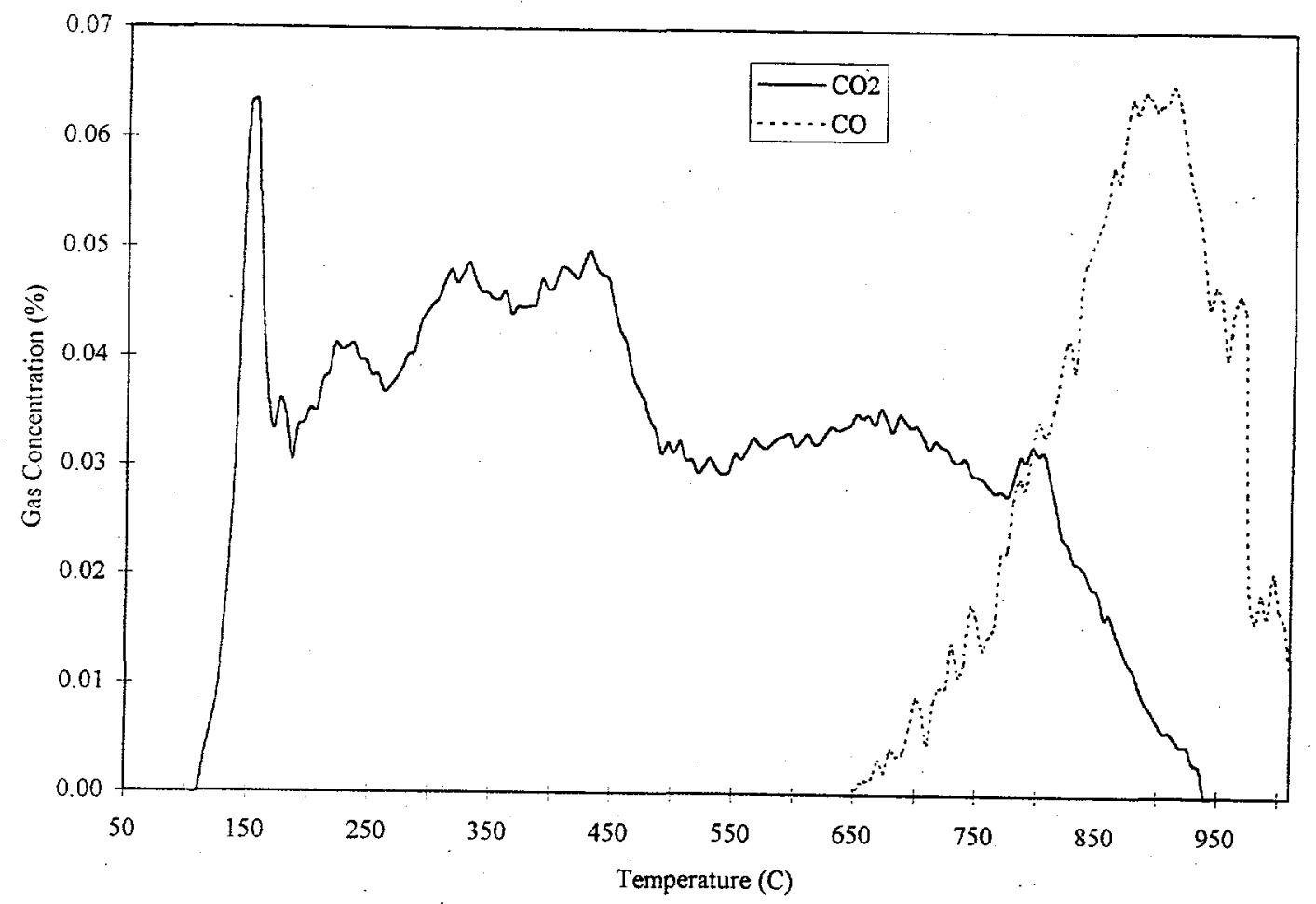

Figure 3.8 Calibrated GC-MS Results for Carbon in 100\% Helium 


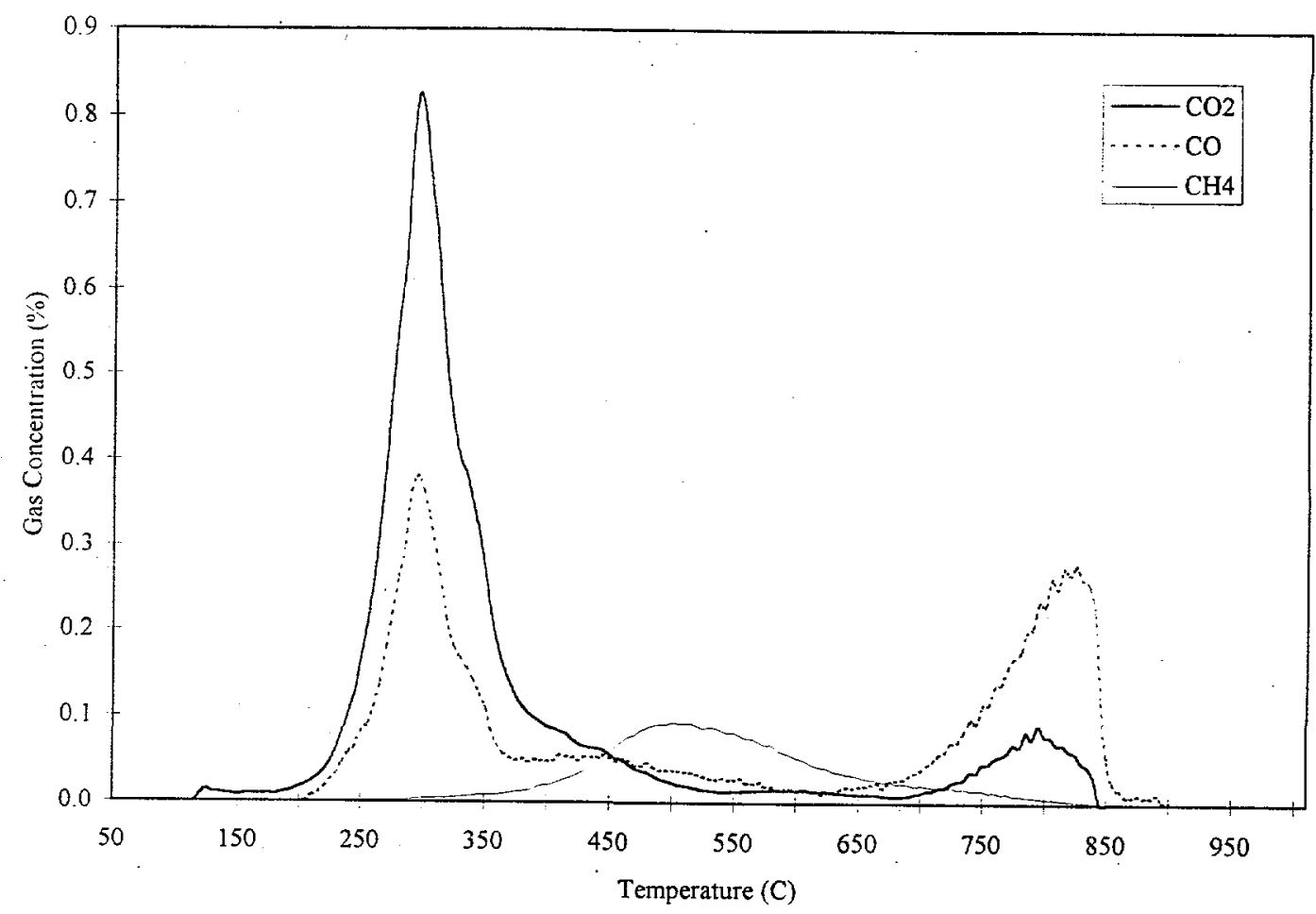

Figure 3.9 Calibrated GC-MS Results for Paper in 100\% Helium

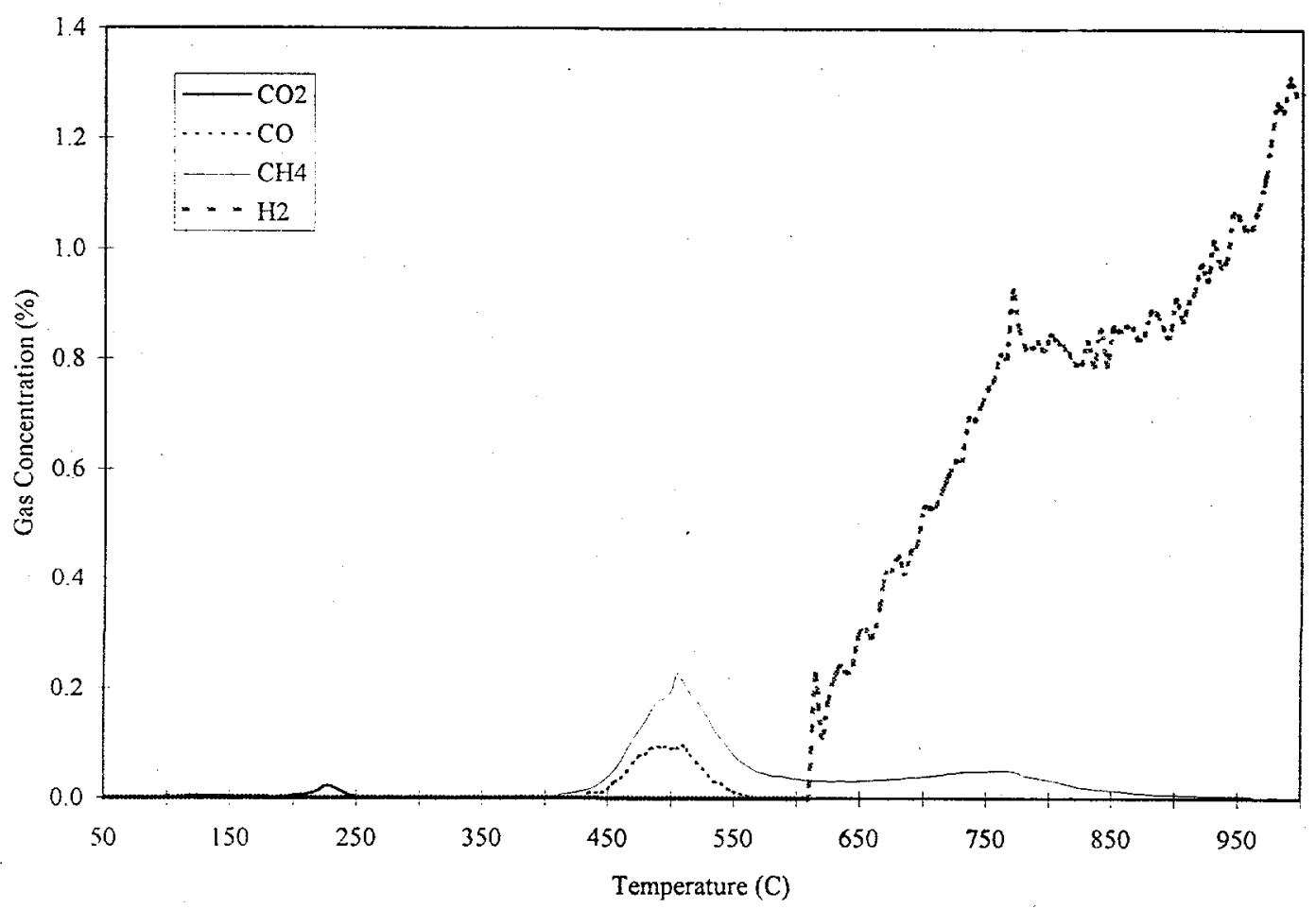

Figure 3.10 Calibrated GC-MS Results for Polyvinylchloride in 100\% Helium 
Perhaps with PVC, and to some extent paper and PP, heating under inert (as well as partially oxidizing) conditions does not favor the complete breakdown of the polymer into low molecular weight species such as methane, but instead produces bond scissions that generate tar products of intermediate molecular weight, which are volatilized but then condense in the cooler parts of the apparatus. The tar products generated from heating PVC were soluble in ethanol. After GC-MS analysis of these products on a different instrument, they were found to contain a complex mixture of unidentifiable alkanes, aromatic compounds, and other species, with significant MS peaks occurring up to 281 mass units.

\subsubsection{Tests of Ash Surrogate D in $100 \%$ Helium}

Analysis of the offgas obtained from heating Ash D, which contained the greatest concentration of plastics and paper, under flowing $\mathrm{He}$ at $5^{\circ} \mathrm{C} / \mathrm{min}$ to $1000^{\circ} \mathrm{C}$ are presented in Figure 3.11 . Predominant species identified were $\mathrm{CO}_{2}, \mathrm{CO}$, and methane. It is postulated that $\mathrm{MS}$ peaks representative of ethane and propane were also detected in significant quantities between about $400^{\circ} \mathrm{C}$ and $700^{\circ} \mathrm{C}$. No $\mathrm{H}_{2}$ was detected, however. When Ash D was heated in air (see TGA/DTA results in Section 3.1.6), the generation of methane and other alkanes was suppressed.

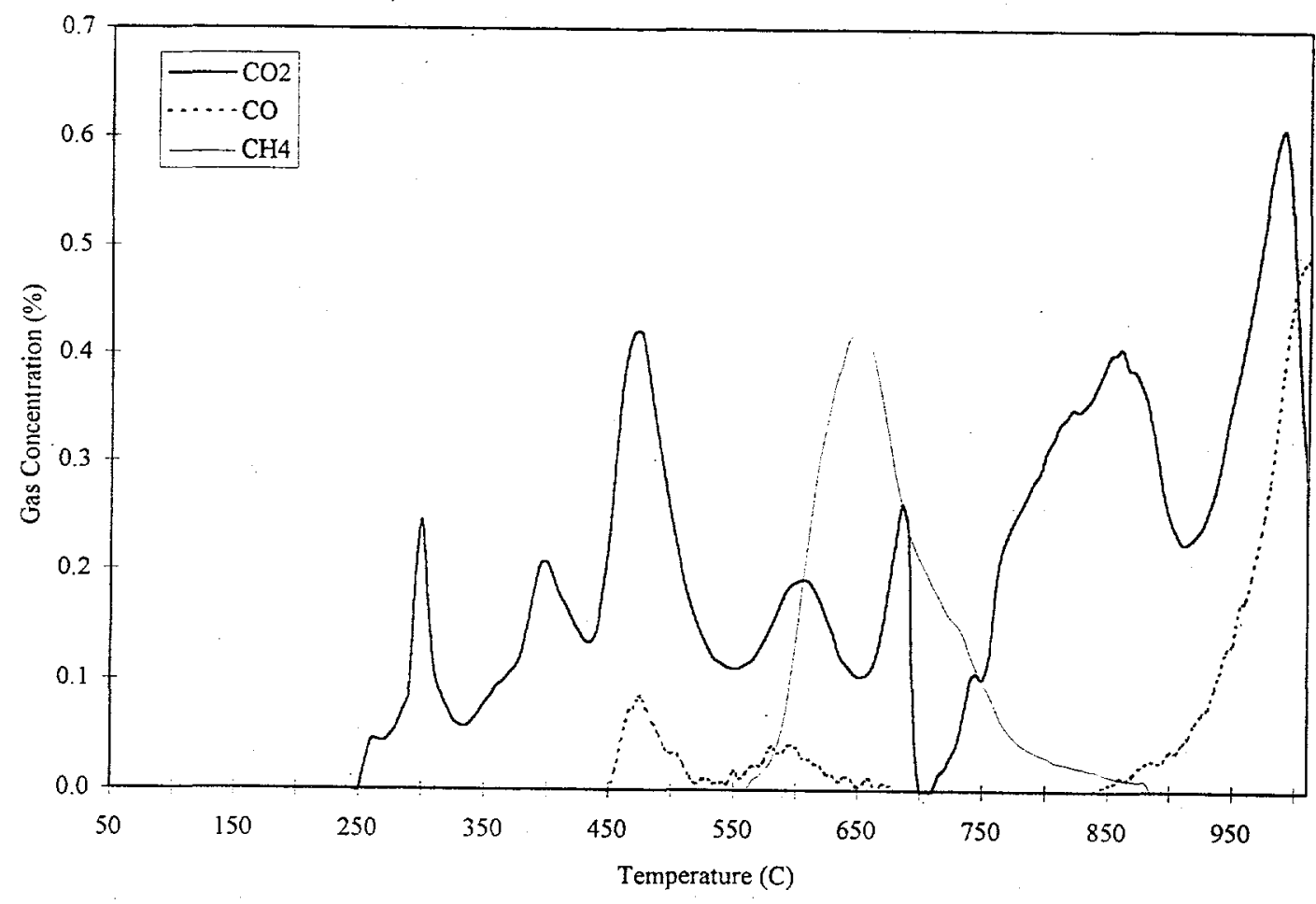

Figure 3.11 Calibrated GC-MS Results for Ash D in 100\% Helium 


\subsubsection{Isothermal Test of Ash $\mathrm{C}$ at $600^{\circ} \mathrm{C}$ in $21 \%$ Oxygen and $79 \%$ Helium}

The offgas evolved when Ash $\mathrm{C}$ was immediately heated to and isothermally held at $600^{\circ} \mathrm{C}$ contained almost exclusively $\mathrm{CO}_{2}$, which was produced at a nearly constant rate from 20 minutes to 160 minutes after starting the test (see Figure 3.12). Data were not collected beyond 160 minutes. These results are consistent with those obtained from the programmed temperature heating of Ash $\mathrm{C}$ in $21 \%$ oxygen, in that at $600^{\circ} \mathrm{C}$, the only significant offgas species detected was $\mathrm{CO}_{2}$.

\subsubsection{Thermogravimetric and Differential Thermal Analysis of Ash D}

Milligram quantities of Ash D were heated in flowing air to temperatures of $1000^{\circ} \mathrm{C}$ in a thermal gravimetric analysis/differential thermal analysis (TGA/DTA) system attached to an infrared spectrometer (IR) to identify offgas products. Triplicate runs were performed. An extremely exothermic reaction was identified by DTA beginning at $\approx 360^{\circ} \mathrm{C}$ and producing $\mathrm{CO}_{2}$ and $\mathrm{H}_{2} \mathrm{O}$ as well as trace amounts of $\mathrm{CO}$ (as detected by IR). A smaller endothermic reaction occurred at approximately $990^{\circ} \mathrm{C}$, producing $\mathrm{CO}_{2}, \mathrm{H}_{2} \mathrm{O}$, and an unidentified compound (a computer search of the IR database yielded no matches). However, no IR bands characteristic of $\mathrm{C}-\mathrm{H}$ bonds were detected during heating. This indicates that combustible gases such as methane and other alkanes are not generated under sufficiently oxidizing environments.

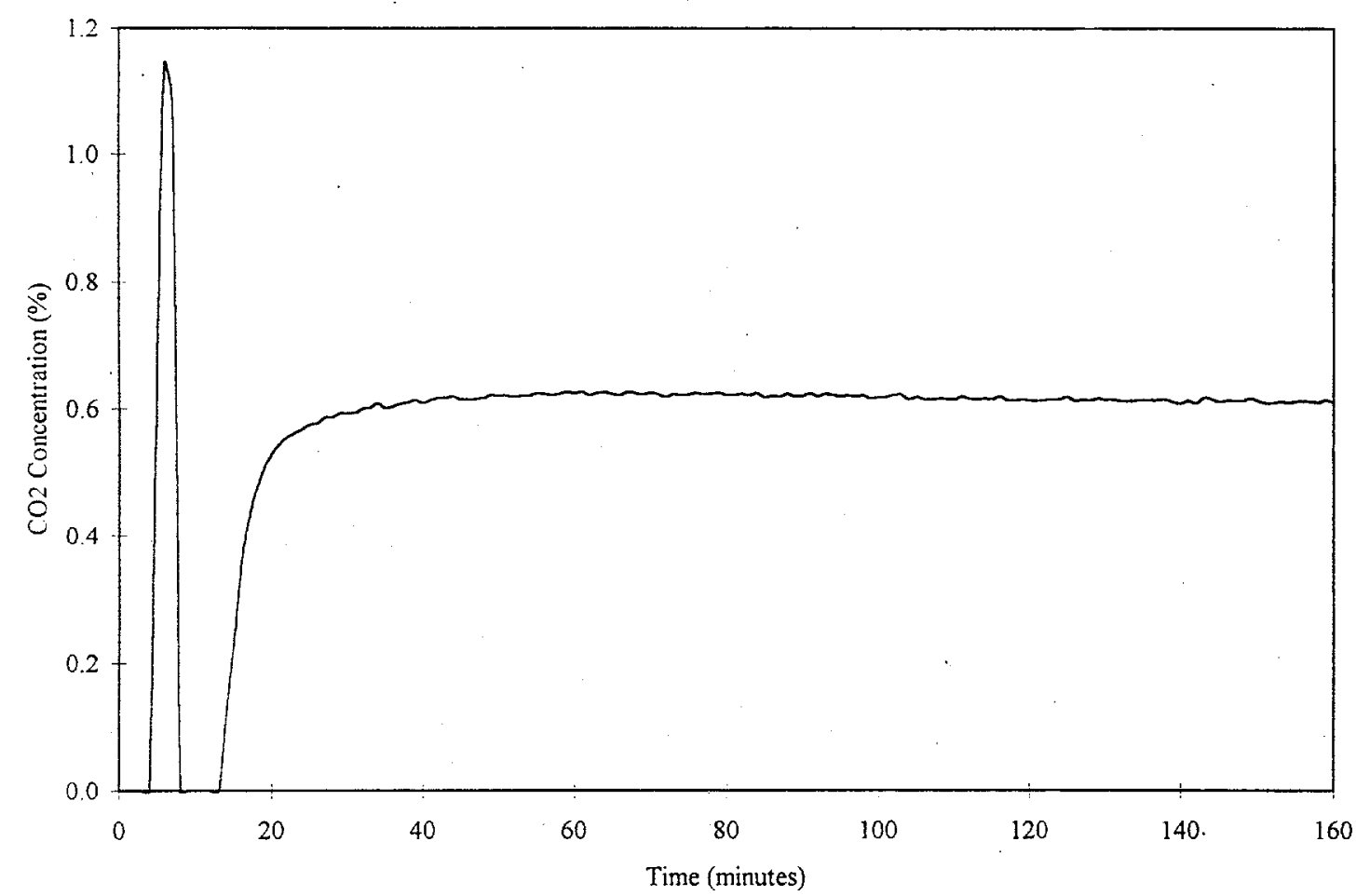

Figure 3.12 Calibrated GC-MS Carbon Dioxide Results for Ash C in $21 \%$ Oxygen at $600^{\circ} \mathrm{C}$ 


\subsection{Bench Top Rotary Calciner Tests}

A total of 15 runs were performed in the rotary calciner. The run date, material tested, amount of material used, and type of injection gas used are summarized in the first five columns of Table 3.2. Runs 1,2 and 3 a were performed using a quartz inner calciner tube. The purpose of these three tests was to determine the behavior of the calciner and identify any processing needs for the subsequent runs with the offgas monitoring system. Run $3 \mathrm{~b}$ through Run 13 all used a stainless steel calciner tube. Offgas monitoring equipment was used for all runs except for the first two.

Table 3.2 Summary of Calcination Runs

\begin{tabular}{||c|c|c|c|c|c|c|c||}
\hline Run \# & Material & $\begin{array}{c}\text { Material } \\
\text { Amount }\end{array}$ & Inlet Gas & $\begin{array}{c}\text { Time at } \\
700^{\circ} \mathrm{C} \\
\text { (Hours })\end{array}$ & $\begin{array}{c}\text { wt\% } \\
\text { C-containing } \\
\text { material }\end{array}$ & $\begin{array}{c}\text { Percent } \\
\text { weight } \\
\text { loss }\end{array}$ & $\begin{array}{c}\text { Vit } \\
\text { test }\end{array}$ \\
\hline 1 & Mix C & $500 \mathrm{~g}$ & Air & 22.6 & 25.5 & 27.6 & Foam \\
\hline 2 & Mix C & $496 \mathrm{~g}$ & Air & 12.5 & 25.5 & 17.9 & Foam \\
\hline $3 \mathrm{a}$ & Mix C & $492 \mathrm{~g}$ & Air & 9.2 & 25.5 & 10.6 & N/A \\
\hline $3 \mathrm{~b}$ & Mix C & $497 \mathrm{~g}$ & Air and $\mathrm{O}_{2}$ & 6.0 & 25.5 & 27.0 & 32.0 \\
\hline 4 & Mix C & $251 \mathrm{~g}$ & Air and $\mathrm{O}_{2}$ & 3.1 & 25.5 & 26.3 & 53.8 \\
\hline 5 & Mix B & $209 \mathrm{~g}$ & Air and $\mathrm{O}_{2}$ & 6.0 & 40.0 & 42.1 & 46.1 \\
\hline $6^{\mathrm{c}}$ & Mix B & $250 \mathrm{~g}$ & Air and $\mathrm{O}_{2}$ & NA & & & \\
\hline $7 \mathrm{a}$ & U of M Ash & $246 \mathrm{~g}$ & Air and $\mathrm{O}_{2}$ & 1.5 & 9.65 & 6.1 & 33 \\
\hline $7 \mathrm{~b}$ & U of M Ash & $260 \mathrm{~g}$ & Air and $\mathrm{O}_{2}$ & 2.0 & 9.65 & 3.0 & 31 \\
\hline 8 & Pozzolan Ash & $245 \mathrm{~g}$ & Air & 1.25 & 5.0 & negligible & 46.2 \\
\hline 9 & BF Slag Ash & $245 \mathrm{~g}$ & Air & 1.0 & 0.0 & 2.9 & 25.9 \\
\hline 10 & Mix C & $262 \mathrm{~g}$ & Air & 8.0 & 25.5 & 15.3 & $(0.04)$ \\
\hline 11 & Mix B & $242 \mathrm{~g}$ & Air and $\mathrm{O}_{2}$ & 6.0 & 40.0 & 40.9 & 57.1 \\
\hline 12 & Mix D & $250 \mathrm{~g}$ & Air and $\mathrm{O}_{2}$ & 6.0 & 46.0 & 45.2 & 60.0 \\
\hline 13 & U of M Ash & $258 \mathrm{~g}$ & Air & 3.0 & 9.65 & 8.1 & 33.3 \\
\hline
\end{tabular}

a Vitrification test involves mixing of calcined material with NBS-1 glass frit to a $40 \mathrm{wt} \%$ ash loading and heating at $800^{\circ} \mathrm{C}$ for two hours. Percentages listed are amount of subsidence.

b Calciner was operated with the both end pieces open (air was not forced through system).

c Filter clogged. Test terminated early. 
For Runs 1 and 2, the end point criterion used was the point of no further weight loss. For the remainder of the runs, the end point criterion was when carbon dioxide levels subsided to near background levels and both the nitrogen and oxygen levels returned to their initial values. As discussed in further detail in this section, runs which were terminated prior to reaching the offgas end point produced a calcined ash that did not perform well in subsequent vitrification tests. Table 3.2 summarizes key results from each of the calciner runs. Individual runs are discussed in greater detail in the remainder of this section. Figures showing the offgas and other variable profiles are all presented in Appendix A.

\subsubsection{Calciner Run \#1 - Mix C}

Run \#1 was conducted with a quartz inner tube and did not involve the injection of any gases nor any offgas monitoring. The purpose of this run was to become familiar with the rotary calciner and to identify operational limitations for the system. The run was performed over the course of a number of days because the system had to be stopped at the end of each day, and allowed to cool, so that the inner tube could be weighed. An end point criterion of no further weight loss was selected, based on batch calcination tests.

Excluding a heating ramp time of 1 hour from ambient temperature, the material was processed at $700^{\circ} \mathrm{C}$ for a total of 22.6 hours. For the 500 gram batch size in the rotary calciner, this corresponds to an average processing rate of $22 \mathrm{~g} / \mathrm{hr}$. For comparison, the same end point was reached for batch calcination tests after 25 hours at $700^{\circ} \mathrm{C}$ for a 350 gram batch of Mix C (average processing rate of $14 \mathrm{~g} / \mathrm{hr}$ ). This indicates that the mixing provided by the rotary calciner enhances the processing rate, even without forced gas flow into the system.

Vitrification tests were performed by mixing the calcined ash with NBS- 1 glass frit to an ash loading of $40 \mathrm{wt} \%$. The sample was placed into a furnace pre-heated to $800^{\circ} \mathrm{C}$ and left for two hours. Foaming was observed and was considered odd, since the end point criterion of no further weight loss had been reached. Further investigation of the processed ash showed that it did not look the same as that produced from batch tests. This difference in appearance was postulated to be the result of residual, unprocessed material getting into the long arms of the calciner tube and then mixing with processed material when the tube was emptied. This was difficult to verify because the quartz tube became cloudy during the thermal processing step.

\subsubsection{Calciner Run \#2 - Mix C}

Run \#2 was conducted with a flow rate of air (about $350 \mathrm{sccm}$ ) into the system but did not involve offgas monitoring. The seal between the end pieces and the inner tube had to be periodically greased due to the thermal decomposition of the lubricant. This lubricant is necessary to allow rotation of the inner tube. This run also used an end point criterion of no further weight loss. 
Excluding a heating ramp time of 1 hour, the material was processed at $700^{\circ} \mathrm{C}$ for a total of 12.4 hours. At the end point, the processed ash had a darker color than the batch calcined samples. This was thought to indicate that some residual carbonaceous material remained in the ash, and this hypothesis was proven to be correct when foaming occurred during the vitrification test. In addition, the calculated weight loss was only $18 \mathrm{wt} \%$ instead of the targeted $26 \mathrm{wt} \%$. Methods to keep the material in the processing section of the inner tube were identified and implemented in future runs (see Section 3.2.3).

\subsubsection{Calciner Run \#3a - Mix C}

Run \#3a is actually two runs combined. Initially, a quartz tube was used with stainless steel end pieces. The steel end pieces had been modified with fittings to allow for the connection of the offgas monitoring system. Two hours into the run, the quartz tube developed a crack and it was decided to replace it with a stainless steel inner tube. The furnace was cooled to about $200^{\circ} \mathrm{C}$ and the test restarted with the steel inner tube.

Air was introduced into the system an average rate of $350 \mathrm{sccm}$. Gas flow rates above $1 \mathrm{~L} / \mathrm{min}$ were attempted but led to plugging of the filters. Plots of the offgas composition as a function of time as an appendix (see Figures $\mathrm{A} 1$ and $\mathrm{A} 2$ ). Figure $\mathrm{A} 1$ shows that the system was oxygenlimited once the plenum reached $500^{\circ} \mathrm{C}$ and the reactions initiated. Periodic spikes shown in the offgas plots were due to the need to break the seal between the end pieces and the inner tube to reapply a lubricant. After 8 hours of processing, it was apparent that the system was still oxygen limited, and would require more than four more hours to reach the end point of no further generation of carbon monoxide and carbon dioxide.

Vitrification tests with the processed material were not performed because the material lost only $10 \%$ of its original weight and did not look completely processed. Actions identified to help in the processing of the ash surrogates and producing suitable end products included the addition of steel wool into the end pieces (to keep material in the reaction volume), changing to a higher temperature lubricant, and addition of pure oxygen as an injection gas option.

\subsubsection{Calciner Run \#3b - Mix C}

Run \#3b successfully reached an end point in which the levels of carbon monoxide and carbon dioxide returned to background levels. The only problem experienced was that the settings for the gas chromatograph did not allow the measurement of carbon dioxide levels above $80 \%$. This was corrected for future runs. Air was introduced into the system at a rate of about $700 \mathrm{sccm}$. Oxygen was introduced into the system about 30 minutes into the run at a level of $300 \mathrm{sccm}$ (air was reduced to $360 \mathrm{sccm}$ ). After 1.75 hours, the flow rate was changed to about $500 \mathrm{sccm}$ oxygen and $150 \mathrm{sccm}$ air. The system was $100 \%$ oxygen at hour 2.75 (flow rate equal to 700 $\mathrm{sccm}$ ). Oxygen was used until carbon dioxide levels returned to background levels. 
Offgas profiles for the run (see Figures A3 and A4) show the onset of the reaction after about 30 minutes (plenum at about $400^{\circ} \mathrm{C}$ ). At this point, the oxygen level was reduced to about zero in the outlet stream while the combustion products increased. A maximum concentration of about $5000 \mathrm{ppm}$ was recorded for carbon monoxide, while hydrogen was about $1500 \mathrm{ppm}$. A single point spike of $1700 \mathrm{ppm}$ methane was observed near hour 4 of the run, but this is likely a measurement error since methane was not detected during any other portion of the run.

Total time at $700^{\circ} \mathrm{C}$ was 6 hours. The final product looked very similar to that produced in the batch calcination tests. Weight loss measurements indicated a loss of $27 \%$. Vitrification tests with the processed material did not exhibit any foaming and produced a product with subsidence of $32 \%$ (subsidence values above $15 \%$ indicate densification and formation of a solid final product). Averaging the weight loss over the total time at temperature gives a rate of about 22 grams per hour.

\subsubsection{Calciner Run \#4 - Mix C}

Run \#4 was performed with half the amount of material used in Run \#3b to determine if the processing rate is linear with the amount of material in the system. Settings on the gas chromatograph were also adjusted to allow for carbon dioxide measurements above 80,000 ppm. Air and oxygen were used for the atmosphere inside the calciner. Oxygen was introduced into the system about 30 minutes into the run at a level of $300 \mathrm{sccm}$ (air was reduced to $360 \mathrm{sccm}$ ). After 1.75 hours, the flow rate was changed to about $500 \mathrm{sccm}$ oxygen and $150 \mathrm{sccm}$ air. The system was $100 \%$ oxygen at hour 2.75 (flow rate equal to $700 \mathrm{sccm}$ ).

Offgas profiles are provided in the appendix (see Figures A5, A6, and A7). As seen previously, the reaction starts after about 30 minutes when the plenum reaches a temperature of $400^{\circ} \mathrm{C}$. The plateau on the carbon dioxide plot at $60,000 \mathrm{ppm}$ is due to control of the injection gas to about a $50 \%$ oxygen mix with nitrogen (see Figure A5). Increased levels to about 100,000 ppm occurred when the inlet gas was switched to pure oxygen. This response indicates that the levels for the combustion gases can be controlled to some degree by the amount of oxygen introduced into the system.

No methane was observed during the run. Peak concentrations observed for carbon monoxide and hydrogen were $2000 \mathrm{ppm}$ and $600 \mathrm{ppm}$, respectively. The maximum ratio of carbon monoxide to carbon dioxide was about 0.09 , and the ratio averaged about 0.01 (see Figure A7). Using the offgas data and assuming that all carbon is from the ash, it was calculated that 70 grams of carbon were processed. This compares well with the calculated carbon content of 59 grams. 
Total time at $700^{\circ} \mathrm{C}$ was 3.1 hours. A very good-looking product was produced (no traces of black, unprocessed carbonaceous material), and was successfully vitrified with no foaming. The measured subsidence was greater than $50 \%$, which indicated very good densification and the formation of a solid product. Weight loss measurements indicated a loss of $26 \%$. Averaging the weight loss over the total time at temperature gives a rate of 22 grams per hour, which is similar to that observed in Run \#3b.

\subsubsection{Calciner Run \#5 - Mix B}

Run \#5 was performed with 200 grams of Mix B instead of 500 grams to minimize the operating time required to obtain offgas data and reach the end point criteria. Compared to Mix C, Mix B is finer and has more carbon. Mix B does not contain any paper or plastic material. Gas flow rate was maintained around $700 \mathrm{sccm}$. Air and oxygen were used for the run: air was used at the beginning and end of the run with the system 100\% oxygen 45 minutes into the run.

Offgas profiles for Run \#5 (see Figures A8, A9, A10, and A11) show different behavior than for runs with Mix $C$. The reaction occurs at a plenum temperature of about $400^{\circ} \mathrm{C}$; however, the profile for carbon monoxide shows increasing and decreasing trends that do not appear to correlate with changes in operating conditions. No methane was observed, while hydrogen shows two peaks. One peak occurred near hour $1(14,000 \mathrm{ppm})$ and the other occurred near hour 7 $(42,000 \mathrm{ppm})$. The maximum ratio of carbon monoxide to carbon dioxide ratio was about 0.11 and the ratio averaged about 0.05 .

Using the offgas data and assuming that all carbon is from the ash, it was calculated that 190 grams of carbon was processed. This calculation indicates that something was not right with the system since the batch sample size was 200 grams, and the calculated amount of carbon present was only 80 grams. The postulated cause for the observed trends and the inconsistency in the calculated amount of carbon present is a gas leak upstream of the calciner. This decreases the amount of oxygen reaching the calciner so the reaction takes longer.

At hour 6.5, the inlet and outlet lines were switched to see if the clog could be dislodged. As the pressure profile shows, normal flow was re-established and the system reached the target endpoint within the next two hours. Measurements showed a $42 \%$ weight loss and compared well with the $40 \%$ predicted. Vitrification of the final product showed that the material was suitably calcined. A subsidence of $46 \%$ was measured in the vitrification test, and a solid final product was formed. 


\subsubsection{Calciner Run \#6 - Mix B}

The purpose of Run \#6 was to redo Run \#5 and try to avoid plugging. A reduced gas flow rate was targeted. This run was terminated early when the new filter placed on the system after Run \#5 became completely clogged. Later, repeat of the Run \#5 conditions was successfully performed and is discussed under Run \#11.

\subsubsection{Calciner Run \#7a - U of M Ash}

Run \#7a was the first run involving an ash produced from an incineration process. Reaction was observed to start at a plenum temperature of $400^{\circ} \mathrm{C}$, consistent with previous runs. Air and oxygen were both used during the run. Total flow rate was maintained around $700 \mathrm{sccm}$. The system was at $100 \%$ oxygen one hour into the run but only needed to be at this level for about 20 minutes. The system was back to $100 \%$ air after 1.5 hours of testing.

Offgas profiles are provided in the appendix (see Figures A12, A13, A14, and A15). The offgas profiles for the levels of oxygen, carbon monoxide, and carbon dioxide show that the processing of the U of M Ash was very quick. The bulk of the combustion reaction appeared to be complete after the first 1.5 hours. Operations continued for another hour, however, because the combustion gas levels had not returned to background levels. Even with this additional time, the levels were still elevated relative to the initial levels, but it was decided to evaluate the product.

As was the case with most of the runs with Mix B and Mix C, no methane was detected. Peak concentrations observed for carbon monoxide and hydrogen were $23,000 \mathrm{ppm}$ and $900 \mathrm{ppm}$, respectively. The maximum ratio of carbon monoxide to carbon dioxide was about 0.21 , and it averaged about 0.04 . Using the offgas data and assuming that all carbon is from the ash, it was calculated that 9 grams of carbon were processed. The actual weight lost was determined to be 15 grams, which suggests that the $U$ of $M$ ash contains other combustible species in addition to carbon.

Total time at $700^{\circ} \mathrm{C}$ was 1.5 hours. The final product looked very similar to that produced from the batch calcination tests. Weight loss measurements indicated a loss of $6.1 \%$, which was less than the expected $9.65 \%$ (see Table 2.4). Vitrification tests with the processed material did not exhibit any foaming and produced a solid final product (subsidence of $33 \%$ was measured). Averaging the weight loss over the total time at temperature gives a rate of about 10 grams per hour. This rate is slower than that observed for ash surrogates with unprocessed carbon material. This indicates that tests with actual RFETS ash material, or surrogates subjected to thermal treatment, is needed to determine actual processing times in prototypical calcination equipment. 


\subsubsection{Calciner Run \#7b - U of M Ash}

Run \#7b was performed to verify the observations made in Run \#7a. Processing of the ash was again very quick, with the bulk of the reaction complete within the first hour after the system reached $700^{\circ} \mathrm{C}$. Operations continued for another two hours because the carbon dioxide levels did not return to initial levels immediately after the reaction appeared complete. The flow rates for air and oxygen from Run \#7a were used to make comparison of results easier.

Offgas profiles are provided in the appendix (see Figures A16, A17, and A18). No methane was detected. Peak concentrations observed for carbon monoxide and hydrogen were $33,000 \mathrm{ppm}$ and $1500 \mathrm{ppm}$, respectively. The maximum ratio of carbon monoxide to carbon dioxide was about 0.25 and it averaged about 0.04 . Using the offgas data and assuming that all carbon is from the ash, it was calculated that 11 grams of carbon was processed. The actual weight lost was determined to be 8 grams. Averaging the weight loss over the total time at temperature gives a rate of about 3.9 grams per hour. Offgas data does not indicate why there is a difference in weight loss between Runs \#7a and \#7b. The different rate is significant because it indicates that material heterogeneity will impact the ability to predict processing times for a given material.

Total time at $700^{\circ} \mathrm{C}$ was 2.0 hours. The final product looked very similar to that produced in the batch calcination tests. Weight loss measurements indicated a loss of $3.0 \%$, which was less than the expected $9.65 \%$ and only half of that observed in Run \#7a. Vitrification tests with the processed material did not exhibit any foaming and produced a solid final. The measured subsidence was $31 \%$, which was comparable to the $33 \%$ subsidence measured in Run \#7a. This indicates that unprocessed, gas generating material was not left after calcination.

\subsubsection{Calciner Run \#8 - Pozzolan Ash}

Pozzolan Ash was selected for testing because it has a low carbon content and is produced by an incineration process. The offgas profiles are provided in the appendix (see Figures A19, A20, and A21) and show that the reaction starts at about $400^{\circ} \mathrm{C}$ and is over very quickly. Because oxygen levels did not drop significantly during the reaction period, pure oxygen was not introduced into the system. Air was introduced at a constant flow rate of $700 \mathrm{sccm}$.

Unlike previous runs, no hydrogen was detected during testing. A peak methane concentration of $1220 \mathrm{ppm}$ was observed while the maximum carbon monoxide level was less than $3400 \mathrm{ppm}$. It is not clear why carbon monoxide spikes occurred after hour 1 (the bulk of the reaction appeared to be completed by hour 1). These spikes may be baseline noise from the gas chromatograph (the carbon monoxide peak for this system is prone to noise). Using the offgas data, the calculated amount of carbon processed was only 0.13 grams. This level is less than the 12.25 grams of carbon that is predicted using a carbon content of $5 \mathrm{wt} \%$. This difference is probably due to the presence of inorganic carbon that does not readily oxidize. 
Total time at $700^{\circ} \mathrm{C}$ was 1.25 hours. The final product did not look much different then the starting material. Measured weight loss from the system was negligible, which is consistent with the offgas data. Vitrification testing with the material produced a very solid final product (measured subsidence was 46\%). These results indicate that the composition for the Pozzolan Ash is incorrect or that the carbon is in a form which does not readily combust at $700^{\circ} \mathrm{C}$.

\subsubsection{Calciner Run \#9 - BF Slag Ash}

BF Slag Ash was selected because the provided composition data indicated that there was no carbonaceous material in the ash. Some carbonaceous material was present in the sample tested, as shown by the production of carbon monoxide and carbon dioxide at the same time that oxygen is consumed. The consumption of oxygen is an indication these gases are not decomposition products from a carbonate in the ash. Pure oxygen was not introduced into the system because oxygen levels did not drop significantly. Air was introduced at a constant flow rate of $700 \mathrm{sccm}$.

Offgas profiles are provided in the appendix (see Figures A22, A23, A24, and A25). No methane was detected. A peak hydrogen concentration of $700 \mathrm{ppm}$ was observed while the peak for carbon monoxide was $2200 \mathrm{ppm}$. Spikes of combustion gases were not observed after the bulk reaction appeared to be complete. Using the offgas data, the calculated amount of carbon processed was less than 1.5 grams. Based on the ash composition, no mass loss was expected.

Total time at $700^{\circ} \mathrm{C}$ was 1.0 hour. The final product was darker than the original sample (the untreated BF Slag is white). Measured weight loss was 7 grams ( $2.9 \%$ of the original mass) instead of the expected loss of no weight. Further analysis of the ash is required to determine what species may have been lost during the calcination process. Vitrification testing of the processed material produced a good final product (measured subsidence was $26 \%$ ).

\subsubsection{Calciner Run \#10 - Mix C}

Mix $\mathrm{C}$ was again processed, but with only air as an injection gas. The batch size was half that used in Run \#3a with the intent of reducing the time needed to get to the offgas end point criteria. The run was terminated early because scheduling conflicts did not allow operating personnel to continue the run to the projected completion. Total operating time was 9 hours and projected time to completion was an additional 6 hours. Testing to completion for Mix $\mathrm{C}$ with only air injected will require two shift operations, and is planned for a future run. Data collected did not show any trends not observed previously for Mix C (see Figures A26, A27, A28, and A29). 


\subsubsection{Calciner Run \#11 - Mix B}

The purpose of Run \#11 was to repeat Run \#5. This was successfully accomplished, and reduced flow conditions like those seen in Run \#5 were not experienced. Air and oxygen were both used for the run, with a total flow rate of $700 \mathrm{sccm}$. The injection gas was $100 \%$ oxygen about 40 minutes into the run. The injection gas was changed to $100 \%$ air after 5 hours of operation.

Combustion gas profiles were similar to those seen previously, except for a surge in carbon monoxide production near the end of the run (see Figures A31, A32, A33, and A34). The carbon monoxide levels were observed to reach almost $200,000 \mathrm{ppm}$ (20\%). To reduce this level, operators reduced the flow of inlet gas to the system and reduced the kiln temperature. These measures quench the combustion reaction by limiting the amount of reactant (oxygen injected) and reducing the kinetic driver (temperature). It is not clear from the initial review of the data why this carbon monoxide surge occurred. Processing temperatures were near $700^{\circ} \mathrm{C}$ and the trend was toward completion of the calcination step.

A maximum methane concentration of $240 \mathrm{ppm}$ was observed while that for hydrogen was about $30000 \mathrm{ppm}$. The interesting point is the fact that the hydrogen peak occurred near the middle of the run. Previous profiles showed a peak for hydrogen near the beginning of a run, when the reaction was just starting.

From the offgas data, the calculated amount of carbon processed was 115 grams. This is higher than the 97 grams predicted, based on a carbon content for Mix B of $40 \mathrm{wt} \%$. Measured weight loss was 99 grams, which agrees very well with the predicted amount. The likely cause of the higher calculated amount is a gas leak upstream of the calciner unit, which would reduce the amount of oxygen introduced into the system and result in a longer processing time. Total time at $700^{\circ} \mathrm{C}$ was 6.0 hours. Using the mass of material lost, this gives an average processing rate of 16.5 grams per hour. This rate is slightly lower than the 22 grams per hour observed for tests with Mix C (see Section 3.2.5), which indicates that carbon type influences processing rate. Vitrification testing with the processed material produced a very solid final product (measured subsidence was $57 \%$ ).

\subsubsection{Calciner Run \#12 - Mix D}

Results from Run \#12 were similar to the results from Run \#11. As in Run \#11, carbon monoxide levels surged at about the same time carbon dioxide levels were beginning to decline. Because of operator experience gained from Run \#11, the carbon monoxide increase was limited to a maximum of around $125,000 \mathrm{ppm}(12.5 \%)$. Air and oxygen were both used for the run, with a total flow rate of $700 \mathrm{sccm}$. The injection gas was $100 \%$ oxygen about 40 minutes into the run. The injection gas was changed to $100 \%$ air after 7.5 hours of operation. 
Offgas profiles are contained in the appendix (see Figures A34, A35, A36, and A37). A peak methane concentration of $98,000 \mathrm{ppm}$ was observed near the beginning of the reaction. Note that methane was not observed to any appreciable extent for runs with Mix $\mathrm{C}$ and Mix B. Relative to Mix B and Mix C, Mix D has more paper and plastic components. Peak hydrogen level was about 40,000 ppm and occurred near the beginning of the reaction. Hydrogen spikes were single data points (sometimes caused by helium), while the peaks for methane resulted from multiple data points.

Using the offgas data, the calculated amount of carbon processed was 115 grams. This is comparable to the predicted carbon content of 103 grams for Mix D. Measured weight loss was 117 grams, which agrees with the calculated weight loss and suggests that some carbon may not be accounted for in the prediction. Total time at temperature was 6.0 hours. Combined with the amount of material lost, this gives an average processing rate of 19.5 grams per hour, which is higher than the processing rate observed for Mix B but lower than that observed for Mix C. Vitrification testing with the processed material produced a solid final product (measured subsidence was $60 \%$ ).

\subsubsection{Calciner Run \#13 - U of M Ash}

The purpose of Run \#13 was to determine differences in offgas characteristics and processing time for the $\mathrm{U}$ of $\mathrm{M}$ Ash when only air was injected. Onset of the reaction occurred at the same point as seen in Runs \#7a and \#7b. However, the concentration of carbon dioxide was limited to less than 30,000 ppm (30\%), due to the limited oxygen (see Figures A38, A39, A40 and A41 in the appendix). Carbon monoxide levels did not get above $20,000 \mathrm{ppm}$, and showed a similar increase as in Runs \#11 and \#12 when the carbon dioxide levels began to decrease (this was not observed in the earlier \#7 runs with U of M Ash). Hydrogen levels were higher in Run \#13 than previously ( $3000 \mathrm{ppm}$ versus $900 \mathrm{ppm}$ ), and higher hydrogen levels were observed over a longer period of time.

Using the offgas data, the calculated amount of carbon processed was 12 grams, similar to that calculated for Run $\# 7 \mathrm{~b}$. Measured weight loss was 21 grams, which is $8.1 \%$ of the original mass and close to the predicted amount of $9.6 \%$ (see Table 2.4). Total time at $700^{\circ} \mathrm{C}$ was 3.0 hours. This time gives an average processing rate of 7 grams per hour, which provides further evidence that calcination may require more time for material previously subjected to an incineration process. Vitrification testing with the processed material resulted in a very good final product (measured subsidence of $33 \%$ subsidence) that was similar to that observed from Runs \#7a and $7 \mathrm{~b}$. 


\subsection{Summary of Bench Top Rotary Calciner Runs}

Table 3.3 summarizes the offgas characterization test results from runs performed in the bench top rotary calciner. Except for Run \#1, the ashes which met the run end point criterion were successfully vitrified, with no foaming exhibited. Except for Runs \#5, \#11, and \#13, the levels of carbon monoxide measured were significantly below the lower explosive limit (LEL) of 125,000 ppm $(12.5 \%)$. For runs that approached or exceeded the LEL, a reduction in the inlet oxygen flow and a reduced kiln temperature were successfully used to lower the concentration of carbon monoxide. Full-scale calciner runs would likely use a dilution gas to quench the reaction and minimize the production of carbon monoxide. Similar trends for hydrogen were observed, with the hydrogen levels approaching the LEL of $41,000 \mathrm{ppm}(4.1 \%)$ for the same runs in which the carbon monoxide levels were elevated. The same measures which reduced carbon monoxide levels also reduced the hydrogen levels.

For all of the runs meeting the end point criterion of a return of carbon dioxide to background levels, vitrification testing produced a very solid final product (subsidence of more than $15 \%$ was the main performance measure for densification of the final product). Full-scale vitrification testing with calcined ash surrogates is planned to verify product performance at full-scale and to determine the range of operating parameters. 
Table 3.3 Summary of Offgas Characteristics from Ash Surrogates Treated in a Bench Top Rotary Calciner

\begin{tabular}{|c|c|c|c|c|c|c|c|c|}
\hline Run \# & $\begin{array}{l}\text { Maximum } \\
\mathrm{CO}_{2}, \mathrm{ppm}\end{array}$ & $\begin{array}{l}\text { Maximum } \\
\text { CO, ppm }\end{array}$ & $\begin{array}{l}\text { Maximum } \\
\mathrm{CO} / \mathrm{CO}_{2}\end{array}$ & $\begin{array}{l}\text { Average } \\
\mathrm{CO} / \mathrm{CO}_{2}\end{array}$ & $\begin{array}{c}\text { Maximum } \\
\mathrm{H}_{2}, \mathrm{ppm}\end{array}$ & $\begin{array}{l}\text { Methane } \\
\text { Detected? }\end{array}$ & $\begin{array}{c}\text { Weight Loss } \\
\text { Rate, g/h }\end{array}$ & $\begin{array}{l}\text { End Point } \\
\text { Reached?a }\end{array}$ \\
\hline 1 & N/A & N/A & $\mathrm{N} / \mathrm{A}$ & N/A & $\mathrm{N} / \mathrm{A}$ & $\mathrm{N} / \mathrm{A}$ & 22 & Yes \\
\hline 2 & N/A & N/A & $\mathrm{N} / \mathrm{A}$ & N/A & N/A & $\mathrm{N} / \mathrm{A}$ & ND & No \\
\hline $3 a$ & 270,000 & 12,000 & ND & ND & 2,100 & No & ND & No \\
\hline 4 & $1,000,000$ & 20,000 & 0.09 & 0.01 & 600 & No & 22 & Yes \\
\hline 5 & $1,000,000$ & 90,000 & 0.11 . & 0.05 & 42,000 & No & ND & Yes \\
\hline 6 & ND & ND & ND & ND & ND & ND & ND & ND \\
\hline $7 \mathrm{a}$ & 72,000 & 23,000 & 0.21 & 0.04 & 900 & No & 10 & Yes \\
\hline 10 & 275,000 & 9,500 & 0.09 & 0.02 & 4,300 & No & ND & No \\
\hline 11 & $1,000,000$ & 200,000 & 0.24 & 0.10 & 30,000 & No & 17 & Yes \\
\hline 12 & $1,000,000$ & 125,000 & 0.38 & 0.14 & 40,000 & Yes & 20 & Yes \\
\hline 13 & 260,000 & 20,000 & 0.23 & 0.10 & 3,000 & No & 7 & Yes \\
\hline
\end{tabular}

a End point for Runs \#1, \#2, and \#3a was no further weight loss. For remaining runs it was return of $\mathrm{CO}_{2}$ to background levels.

b $\mathrm{CO}_{2}$ levels above peak width limit of $800,000 \mathrm{ppm}$

$\mathrm{ND}=$ Not Determined 


\subsection{REFERENCES}

Behrens, RG, EC Buck, NL Dietz, JK Bates, E Van Deventer, and DJ Chaiko. 1995.

Characterization of Plutonium-Bearing Wastes by Chemical Analysis and Analytical Electron Microscopy. ANL-95/35, Argonne National Laboratory, Argonne, Illinois.

Bond, WH, JW Doty, JW Koenst, and DF Luthy. 1978. "Volume Reduction of Low-Level, Combustible, Transuranic Waste at Mound Facility," in Proceedings of the 15th DOE Nuclear Air Cleaning Conference, August 7-10, 1978, Boston, Massachusetts.

Cullis, CF, MM Hirschler, RP Townsend, and V Visanuvimol. 1983. "The Pyroysis of Cellulose Under Conditions of Rapid Heating." Combustion and Flame, Volume 49, pp 235-250.

Delegard, CH. 1984. Laboratory Tests on Plutonium Recovery from Rocky Flats Ash Using Nitric Acid-Calcium Fluoride Leaching. RHO-SD-CP-DTR-005, Rockwell Hanford Operations, Richland, Washington.

Luey, J, JD Vienna, H Li, and HL Wigent. 1998. Vitrification Process Option for Rocky Flats Incinerator Ash. PNNL-11770. Pacific Northwest National Laboratory, Richland, Washington.

Smith, PA, JD Vienna, and P Hrma. 1995. "The Effects of Melting Reactions on LaboratoryScale Waste Vitrification," Journal of Material Research, Volume 10, [8] pp. 2137-2149.

Smith-Hansen, L and KH Jorgensen. 1992. Combustion of Chemical Substances and the Impact on the Environment of the Fire Products. Riso-R-651(EN), Riso National Laboratory, Roskilde, Denmark. 
Appendix

Results of Calciner Runs 3-13 


\section{udd 'uo!̣edpuวsuoว 0 ว}

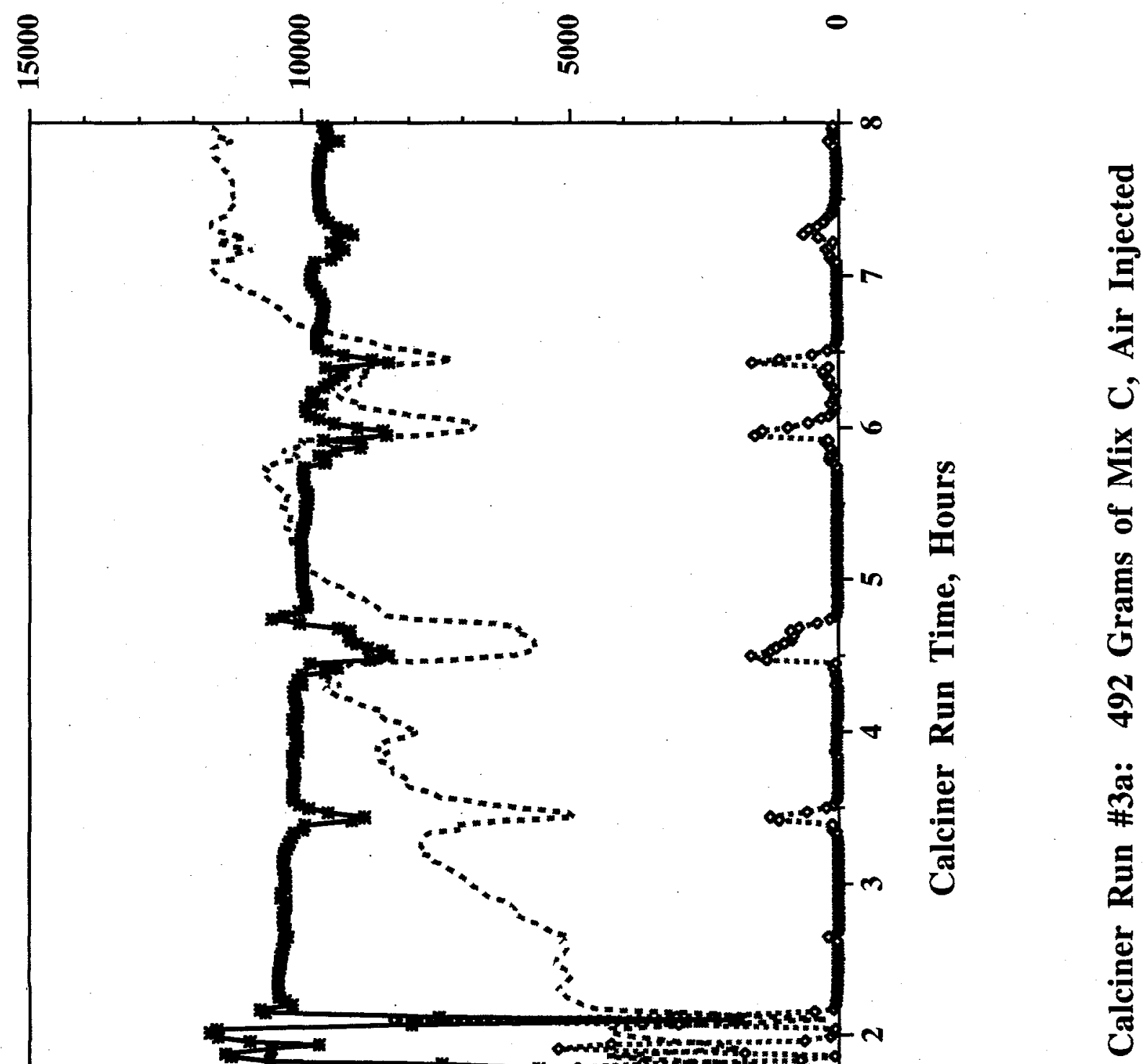

$\dot{2}$
0
0
0
0

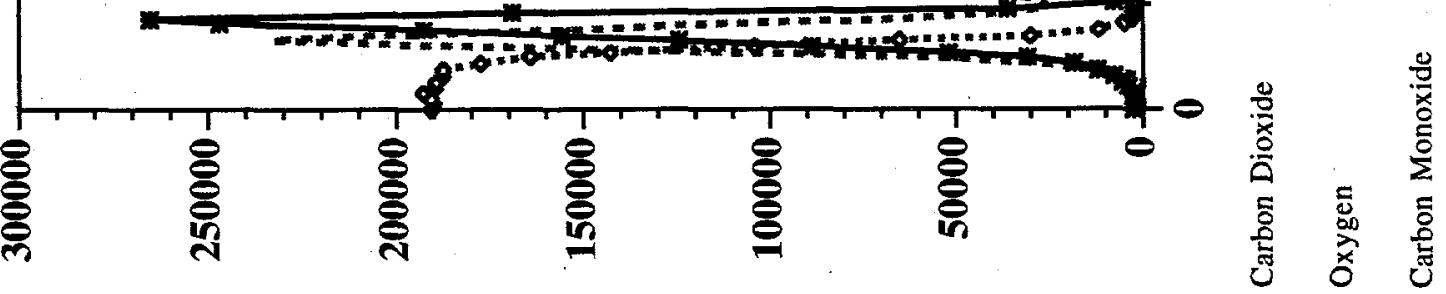

undd 'uo!̣e.1pนววนо 


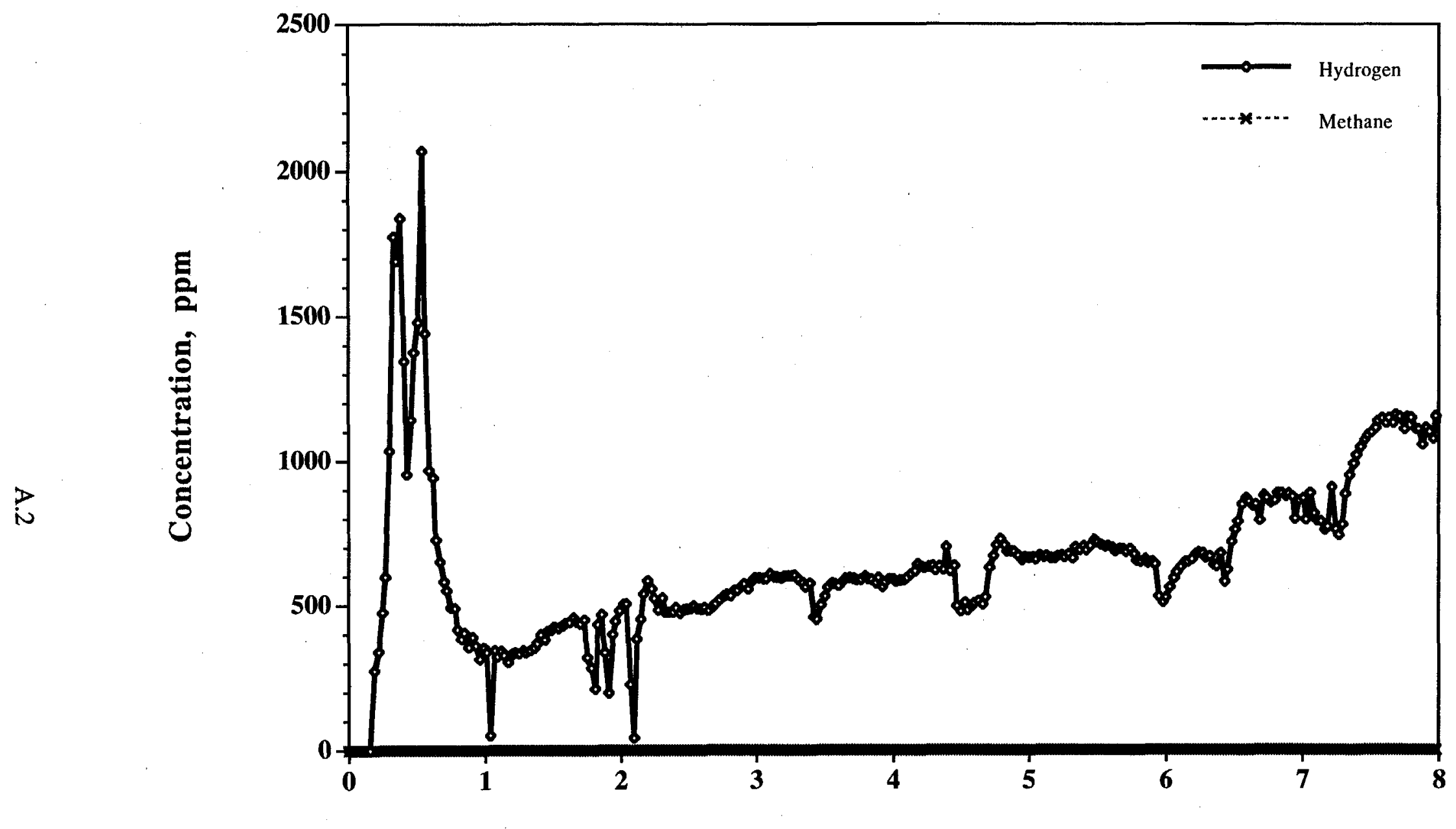

Calciner Run Time, Hours

Figure A2. Calciner Run \#3a: 492 Grams of Mix C, Air Injected 


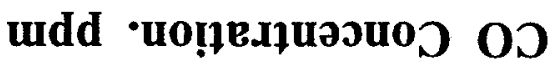

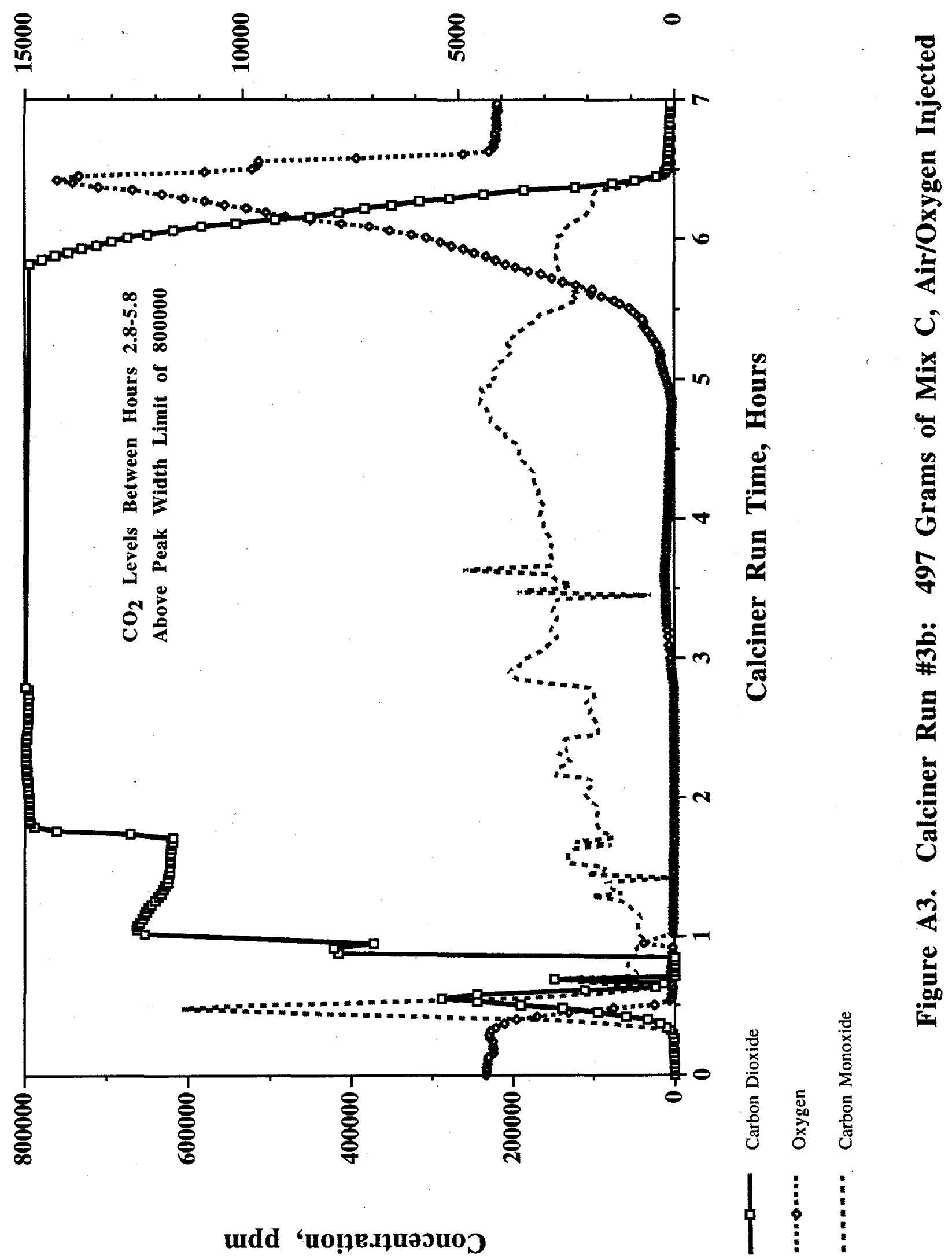




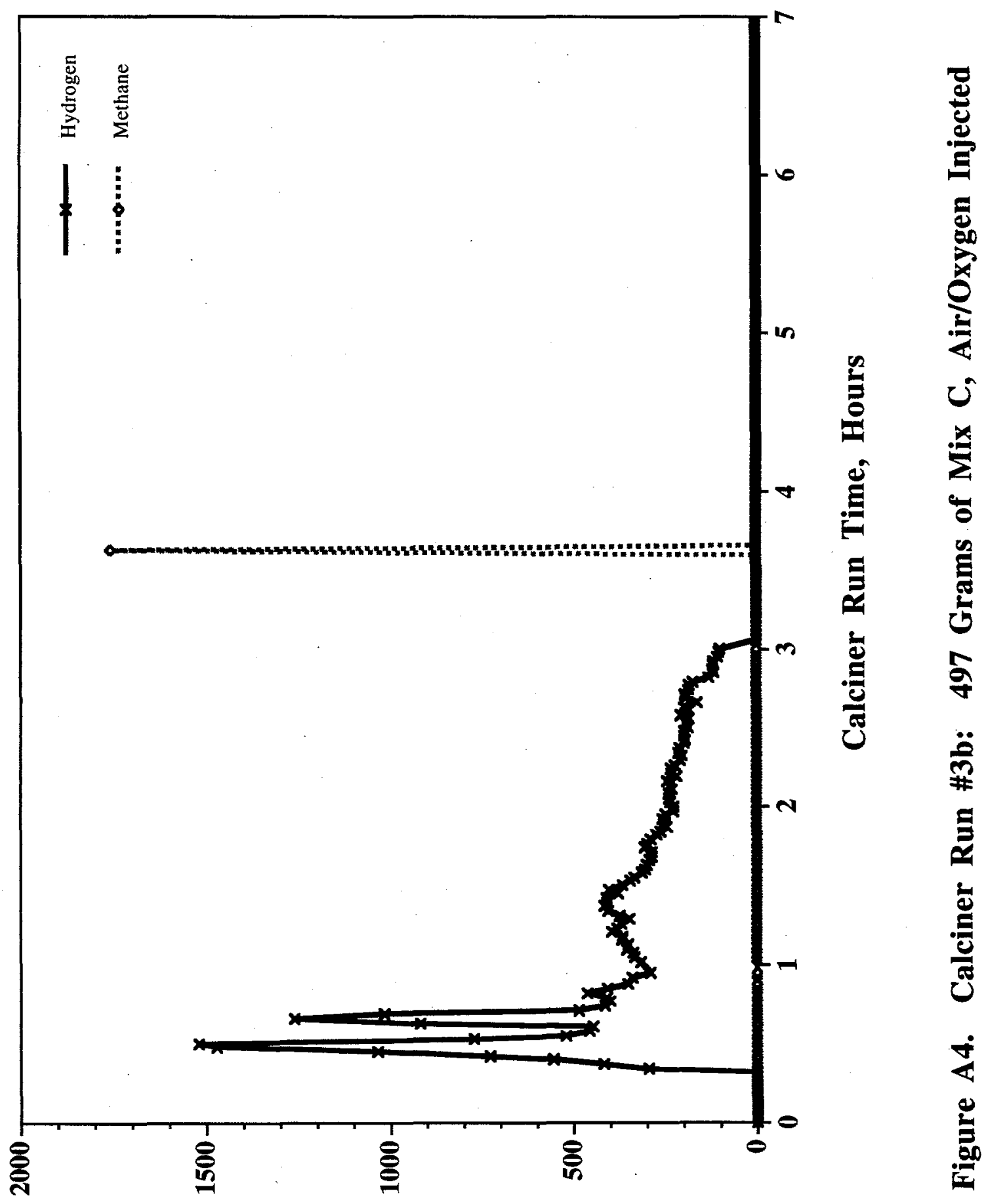

undd 'uo!̣edpuəวoว 


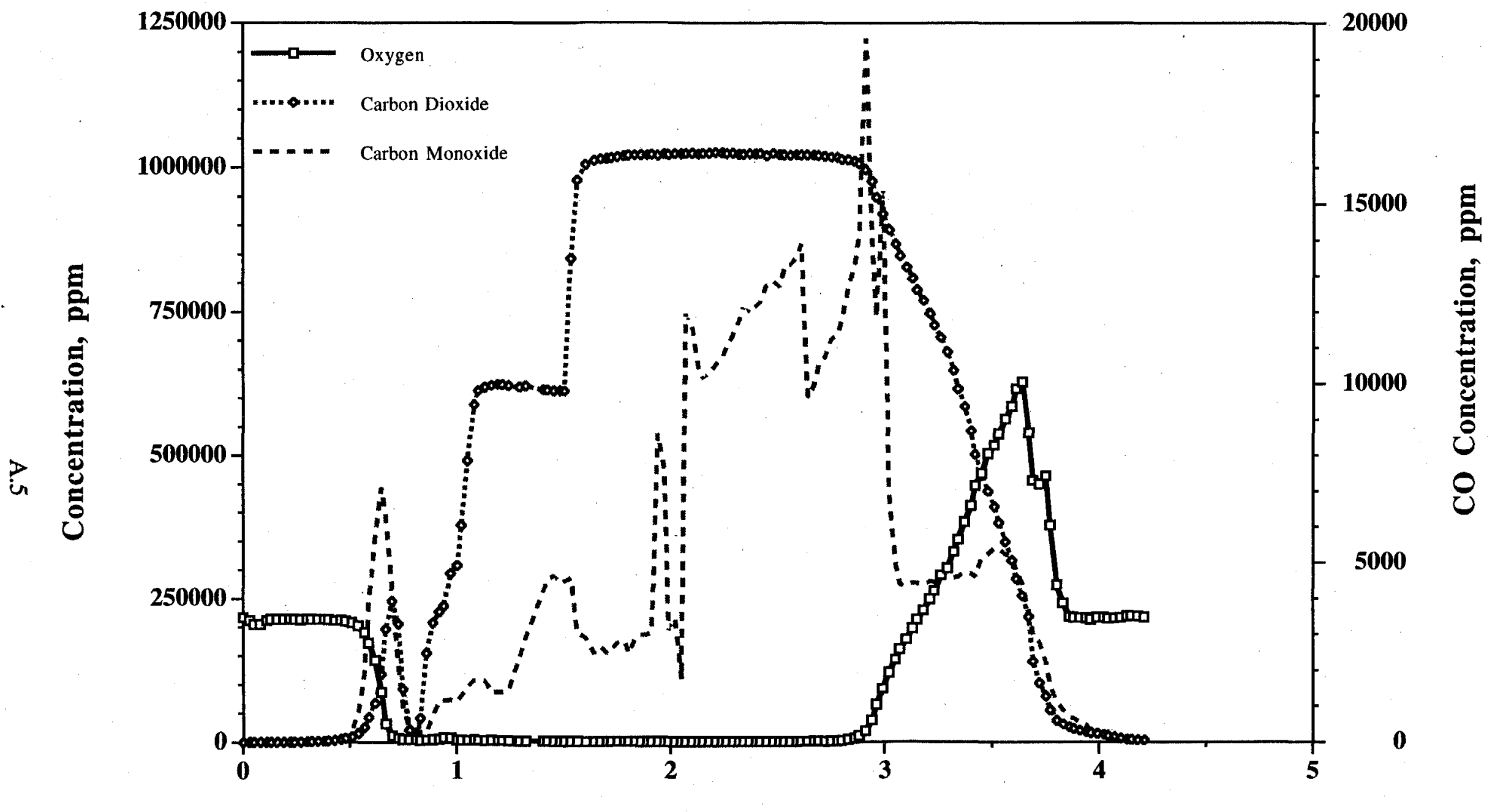

Calciner Run Time, Hours

Figure A5. Calciner Run \#4: 251 Grams Mix C, Air/Oxygen Injected 


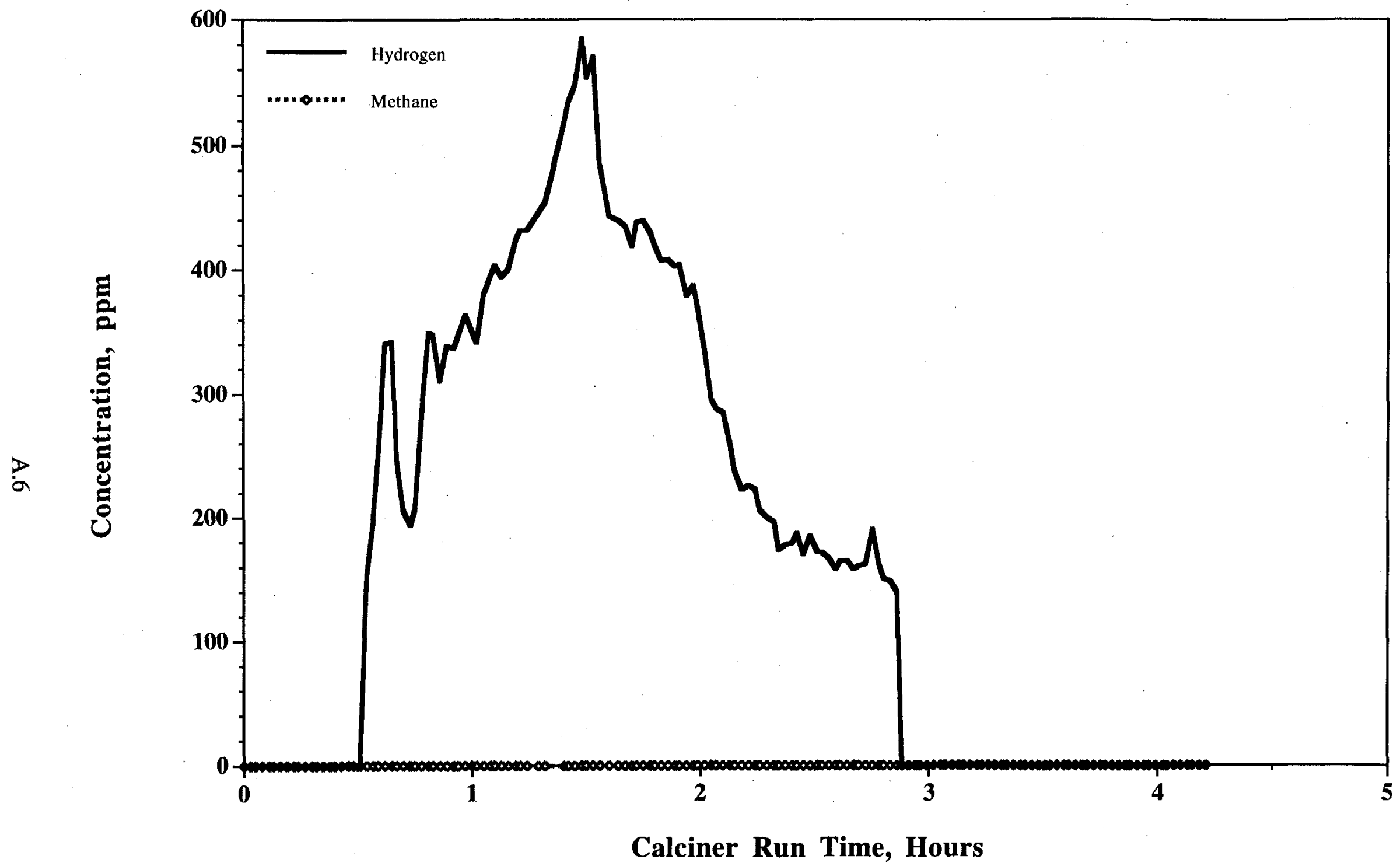

Figure A6. Calciner Run \#4: 251 Grams Mix C, Air/Oxygen Injected 


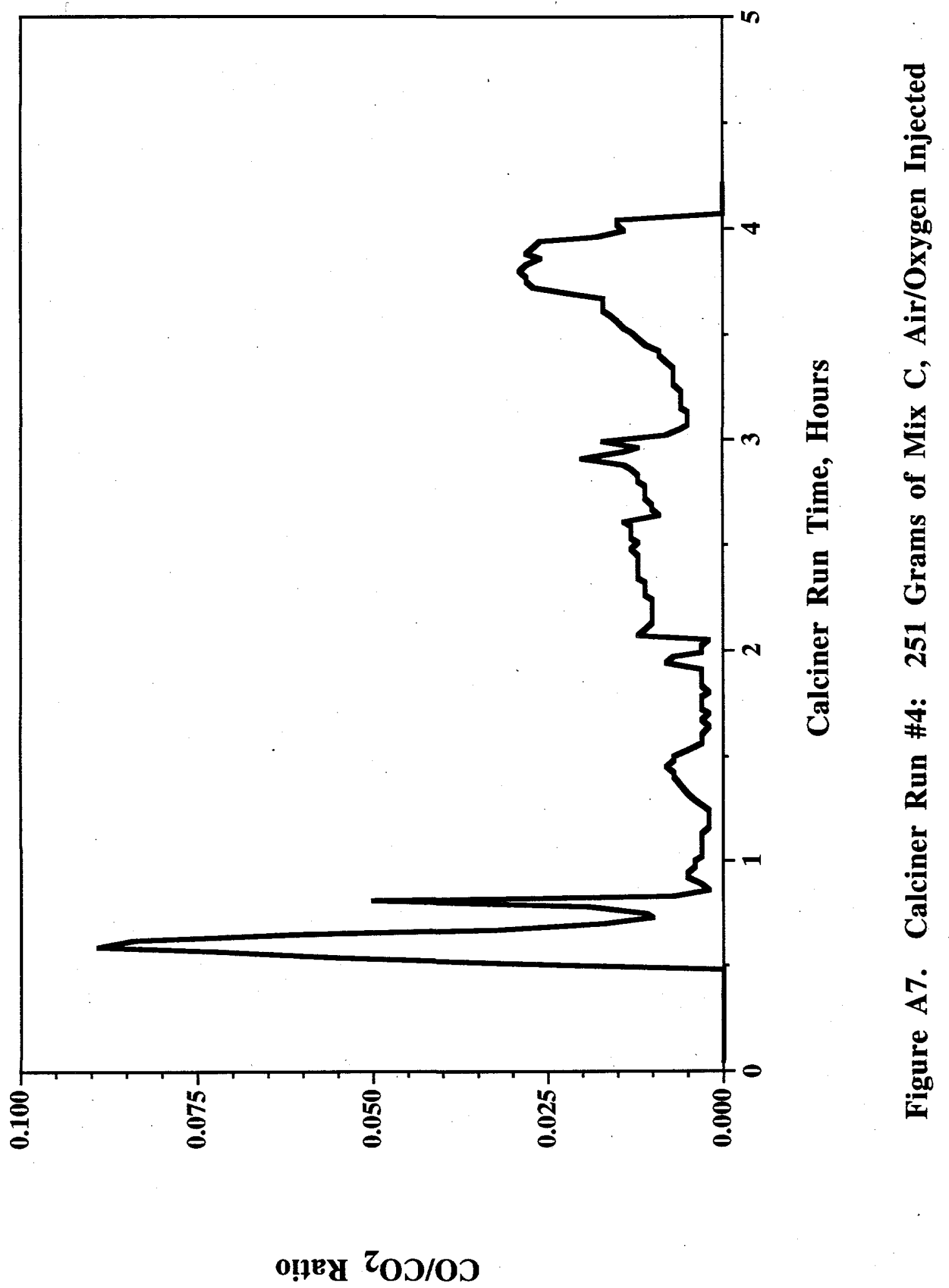

A. 7 


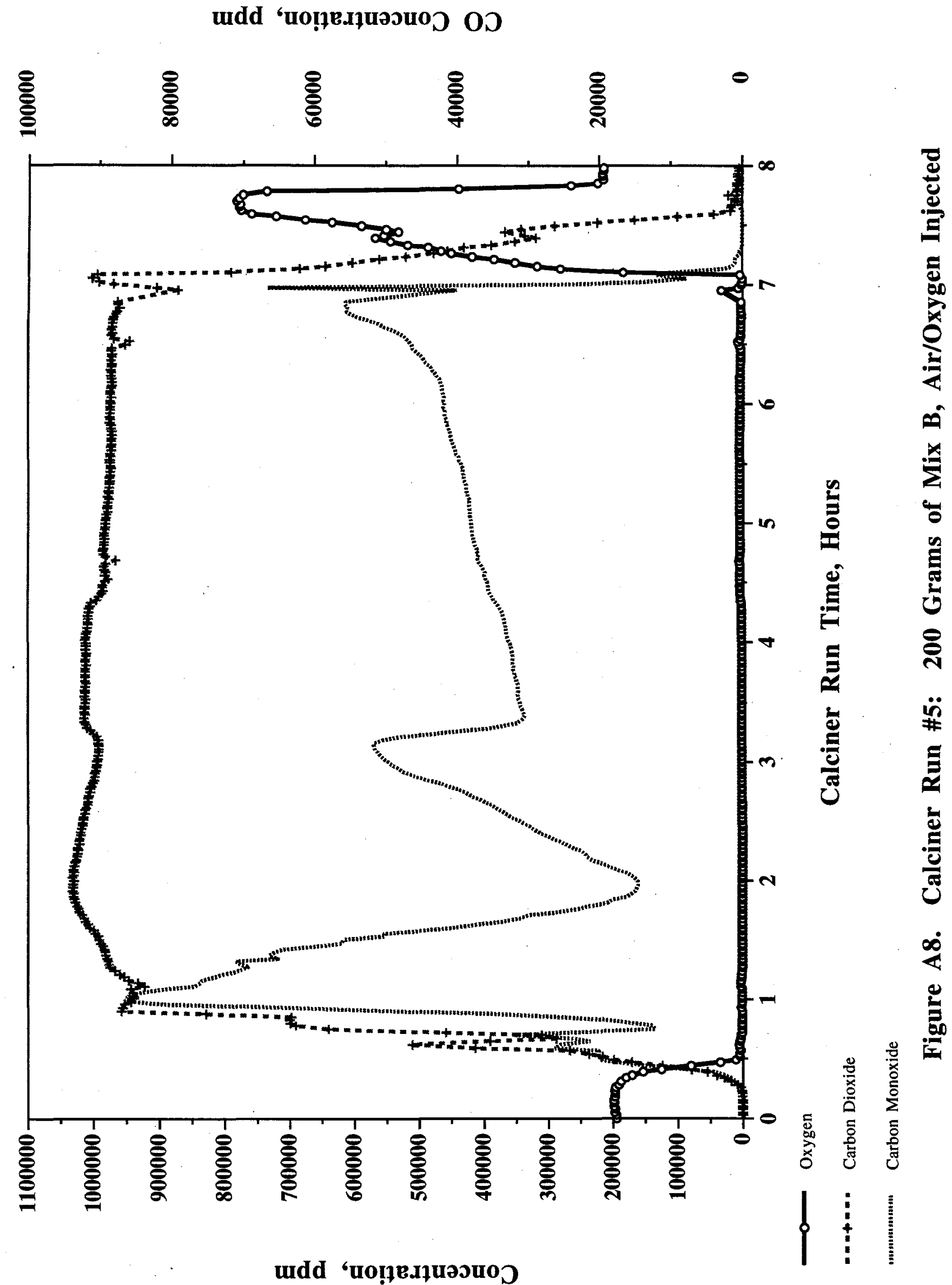




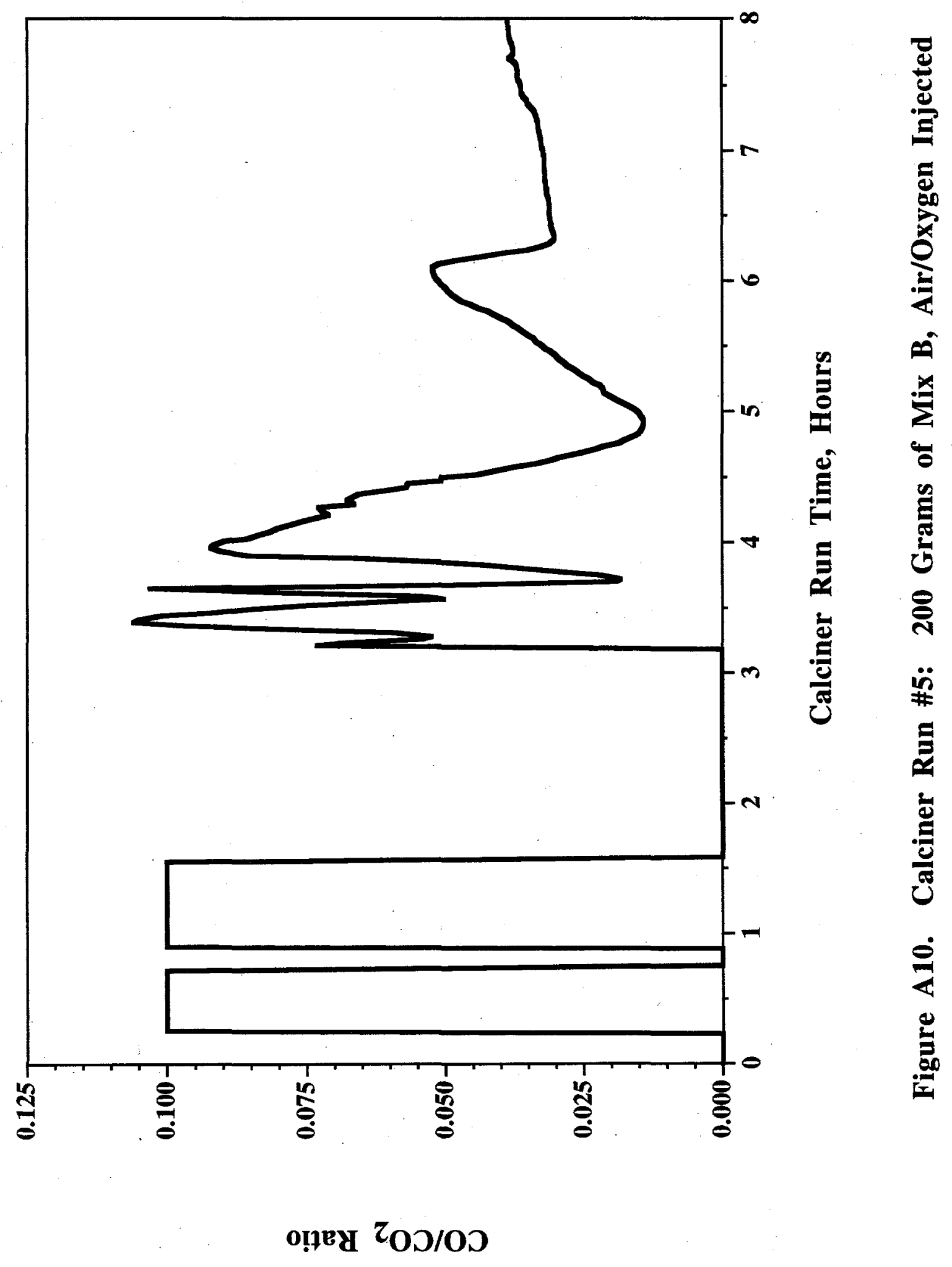

A. 9 


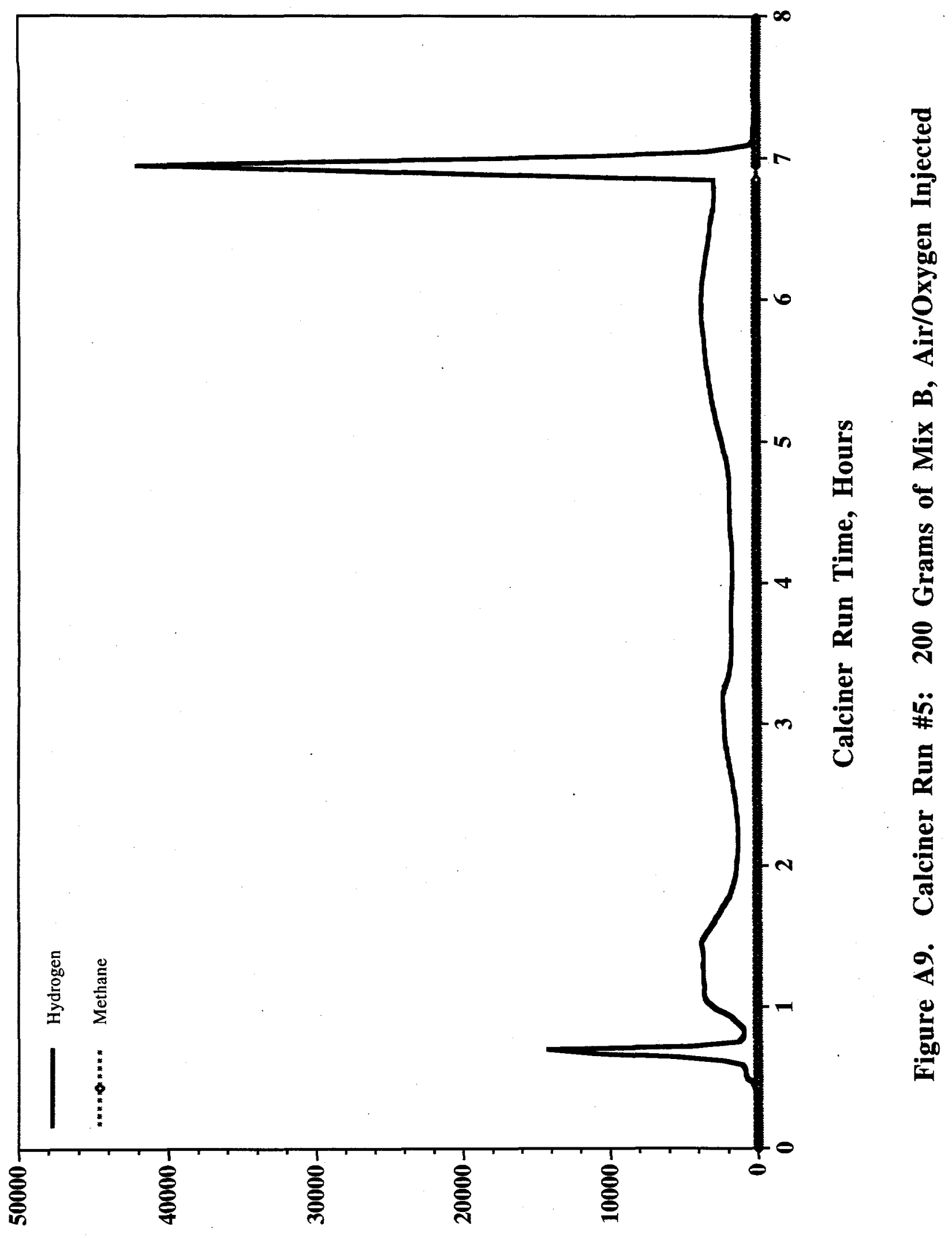

uidd 'uo!̣tedpuəวuоว

A. 10 


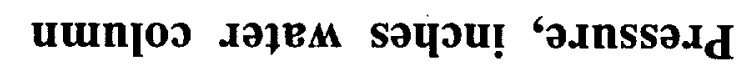

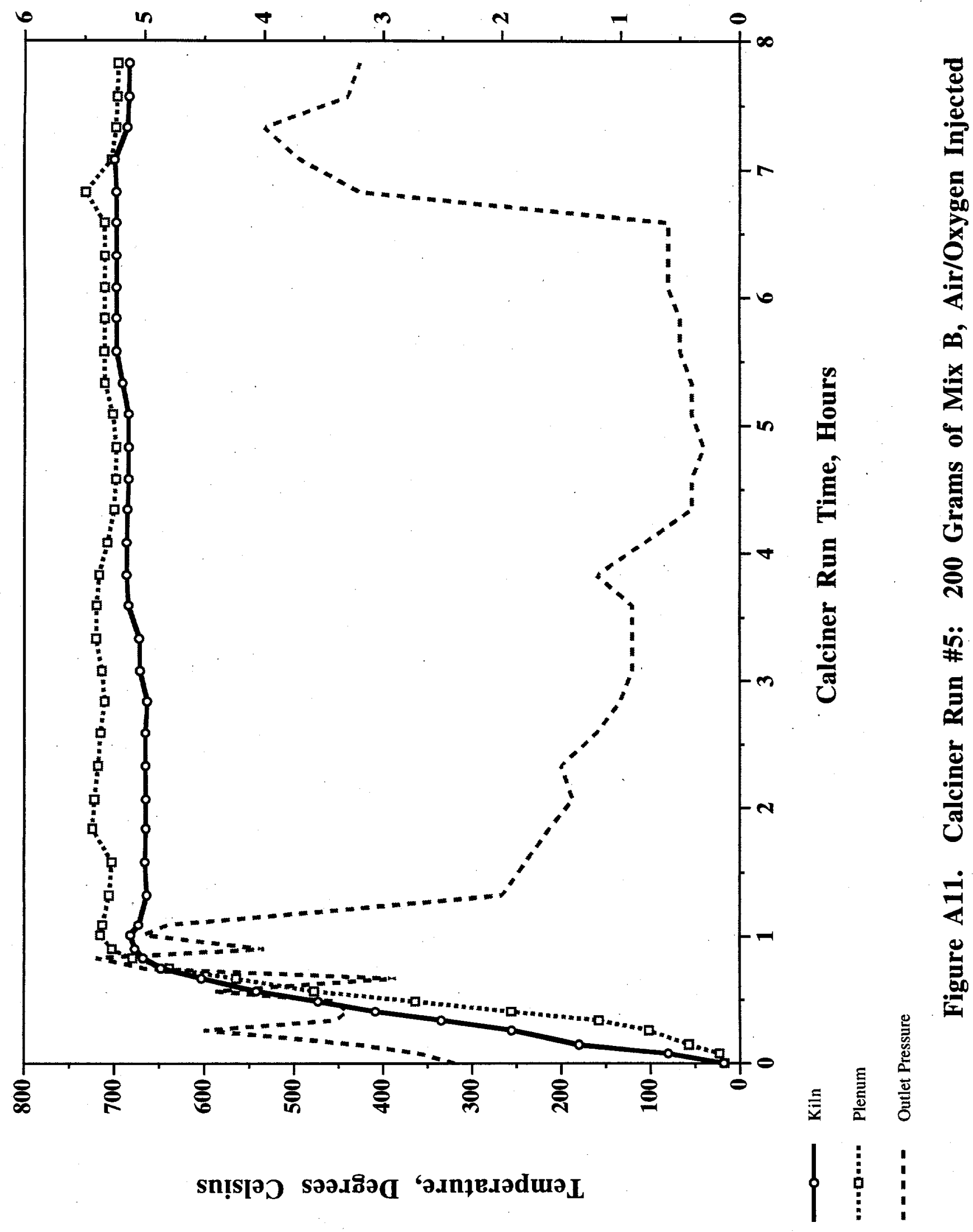




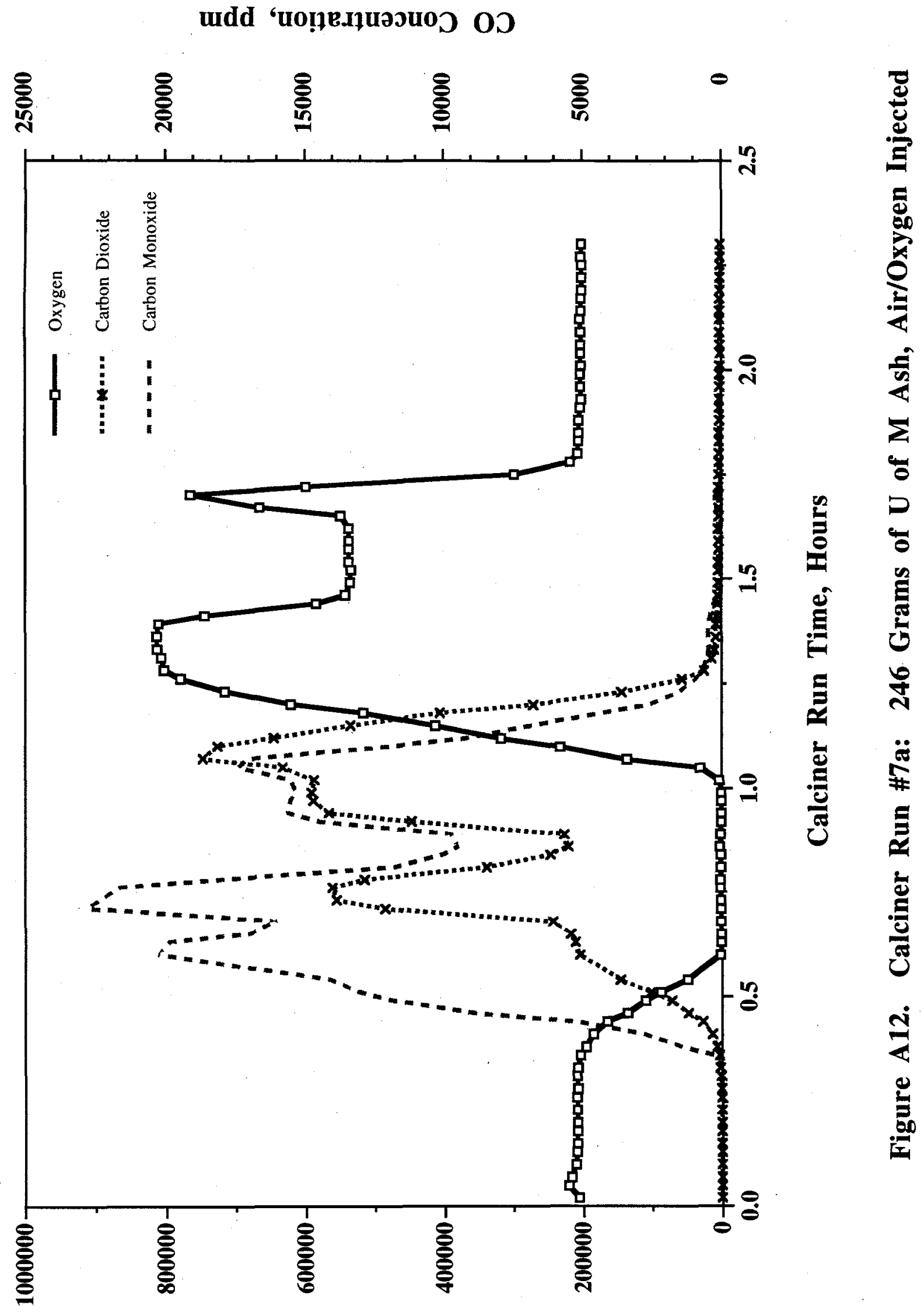

udd 'uo!๋̣.१uววนоว 


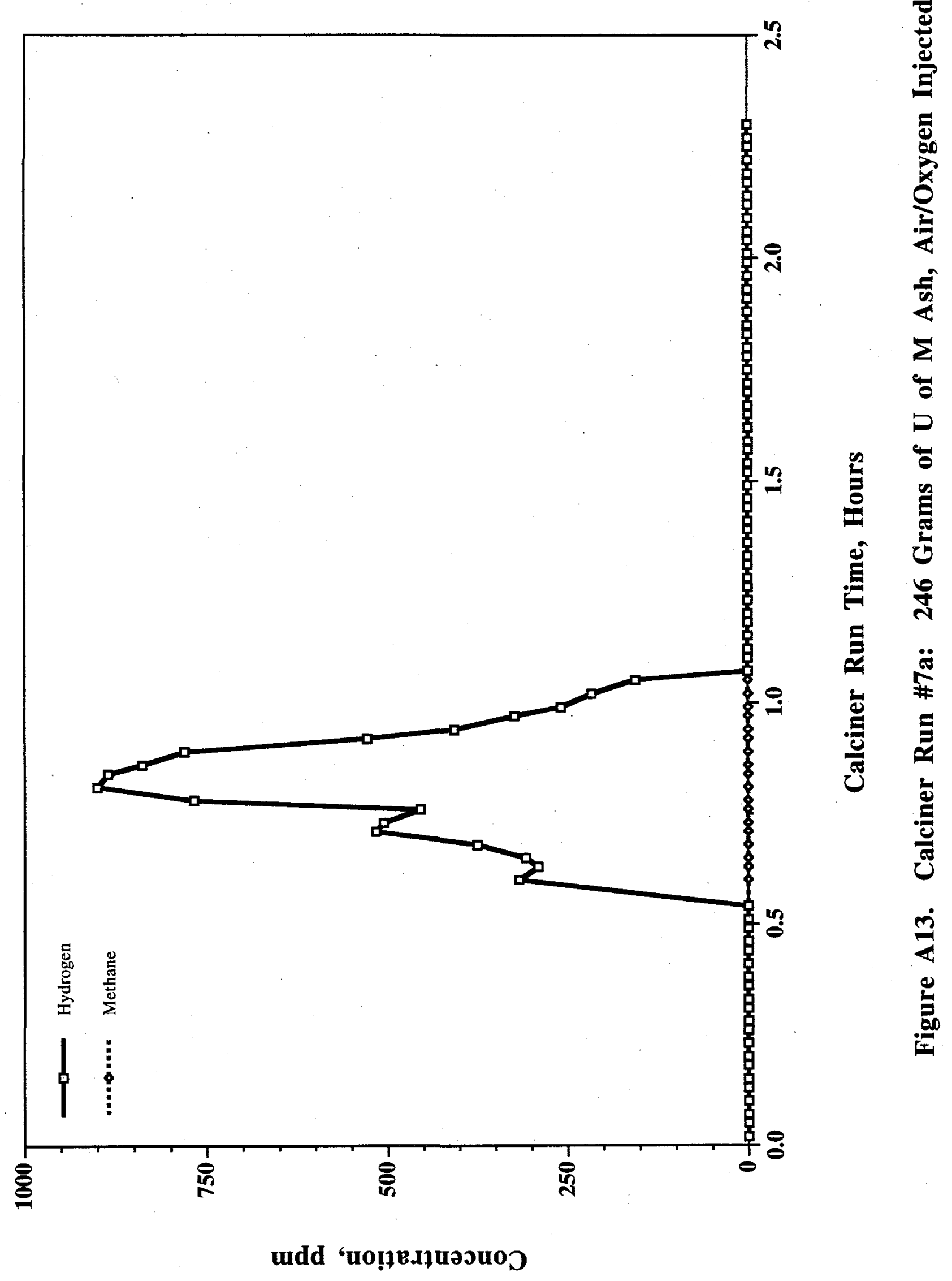

A. 13 


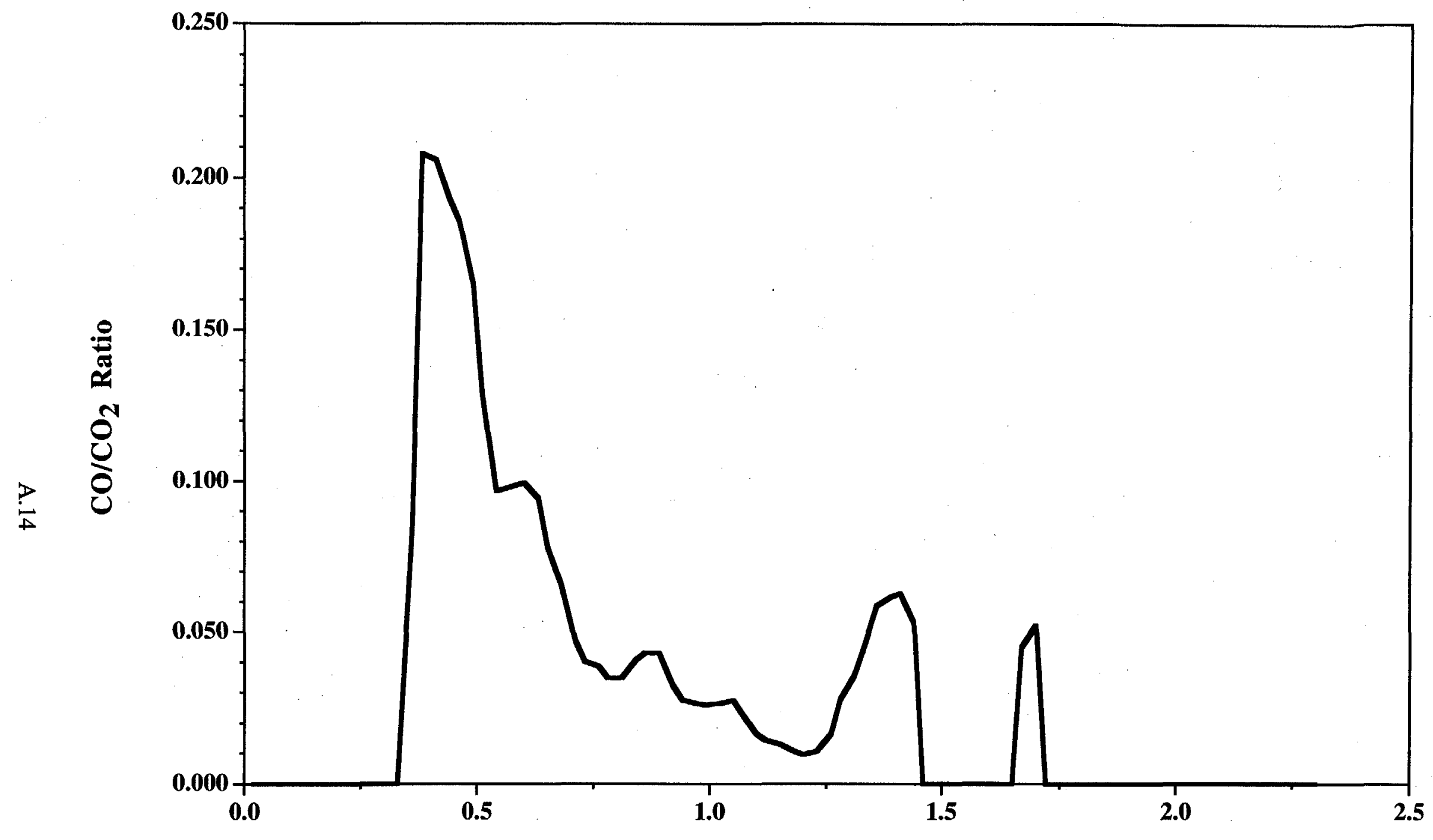

Calciner Run Time, Hours

Figure A14. Calciner Run \#7a: 246 Grams of $U$ of $M$ Ash, Air/Oxygen Injected 


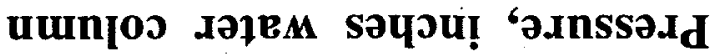

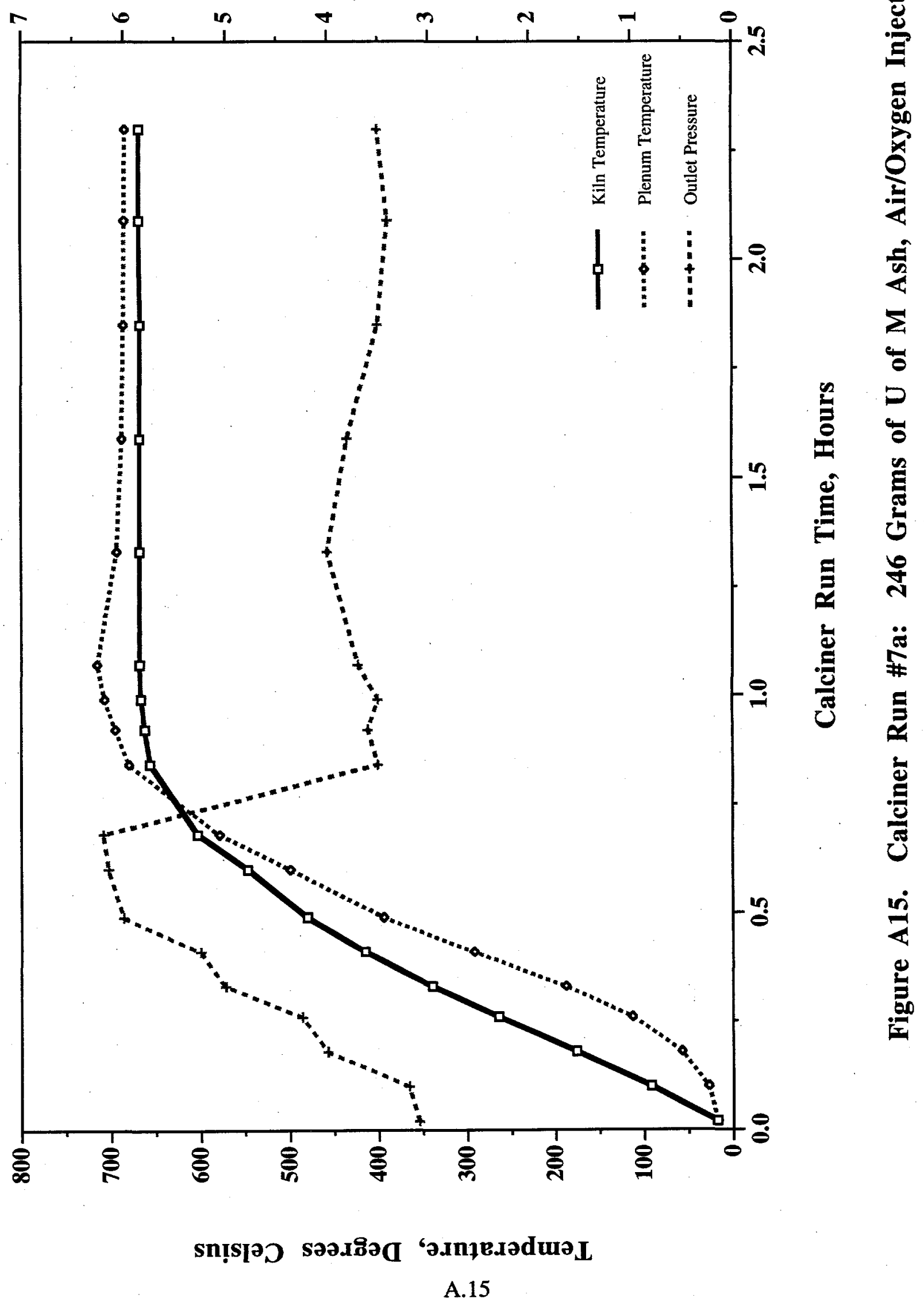




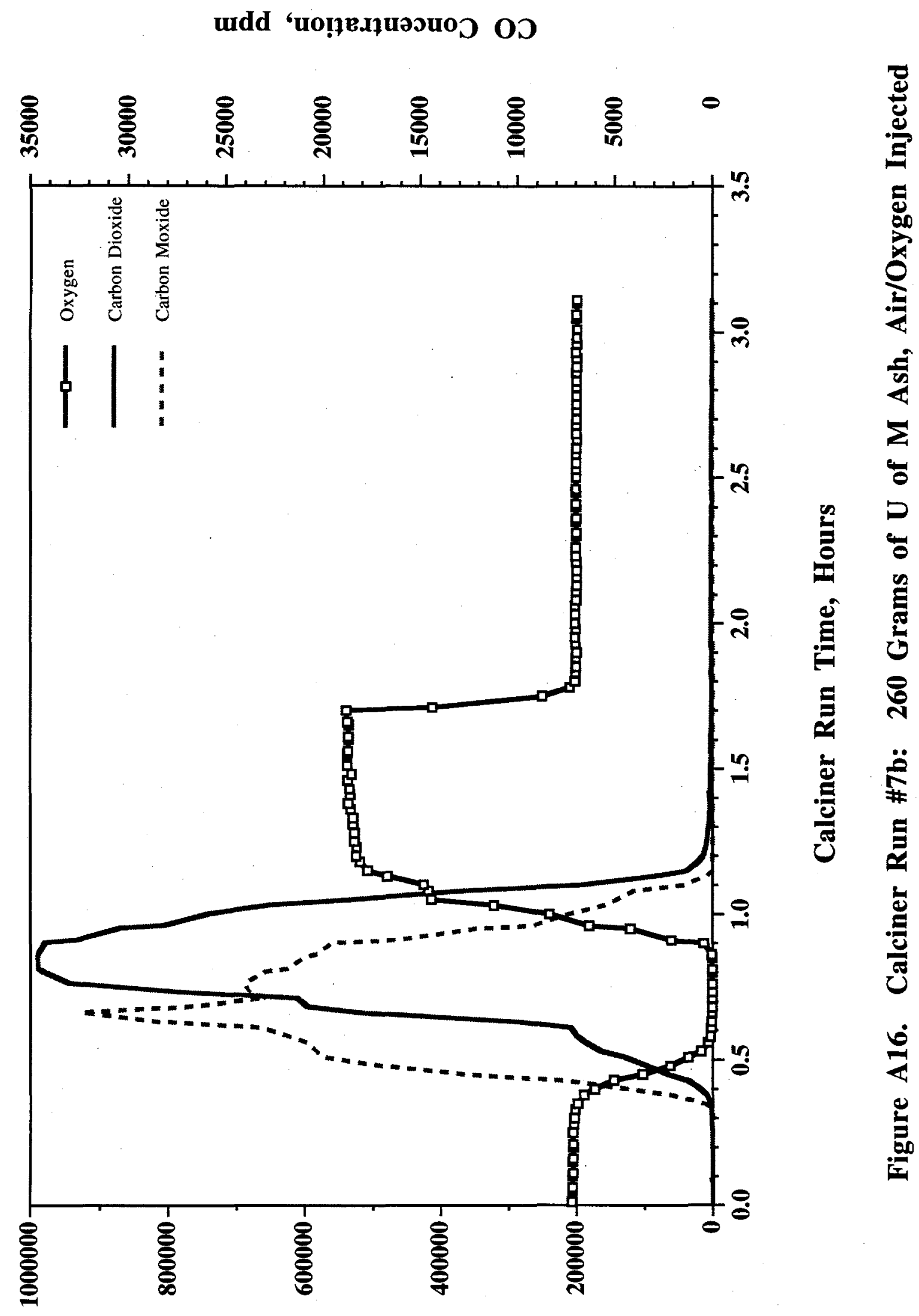

udd 'uo!̣espuəsuoว

A.16 


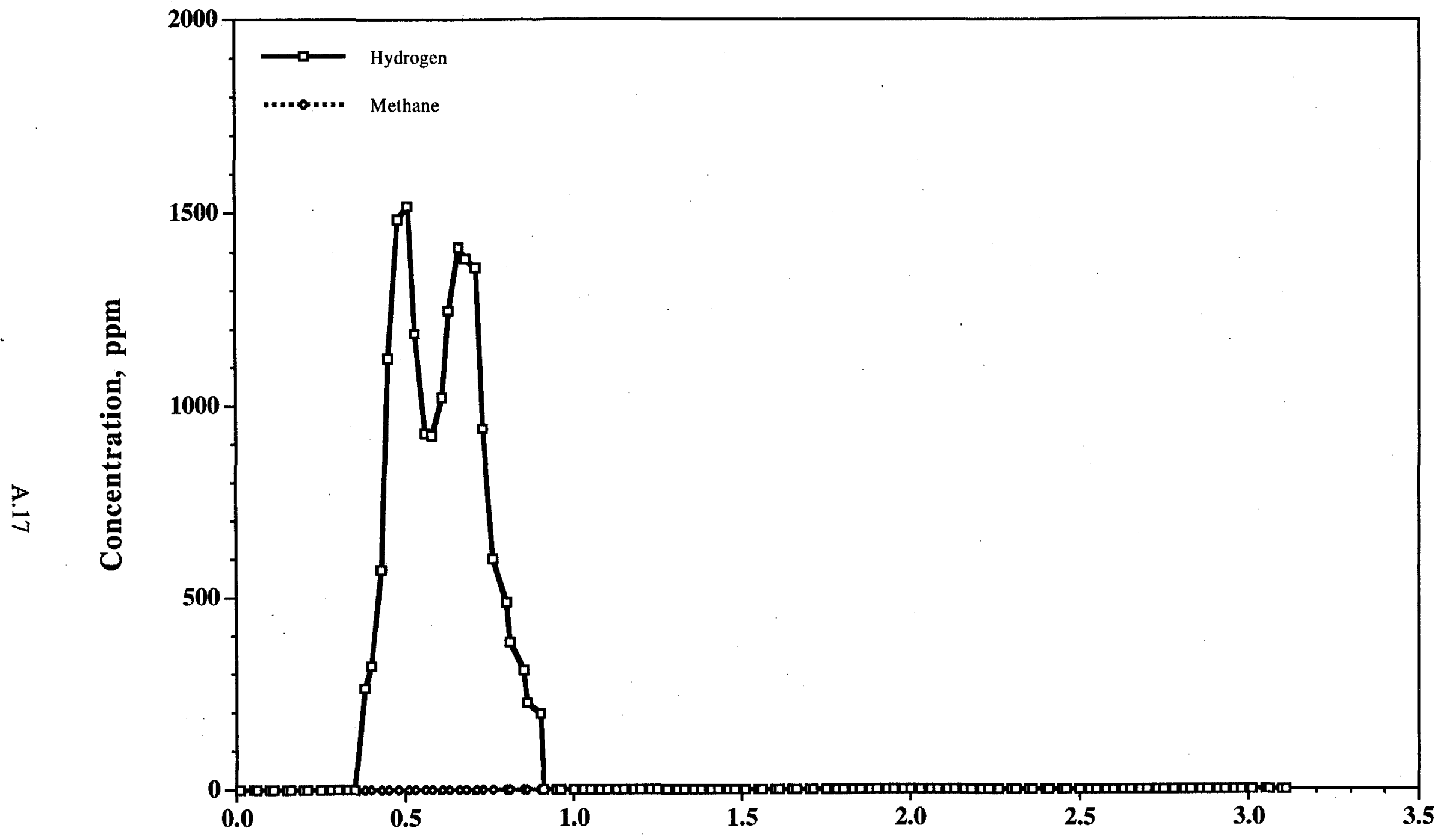

Calciner Run Time, Hours

Figure A17. Calciner Run \#7b: 260 Grams of $U$ of M Ash, Air/Oxygen Injected 


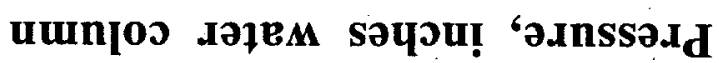

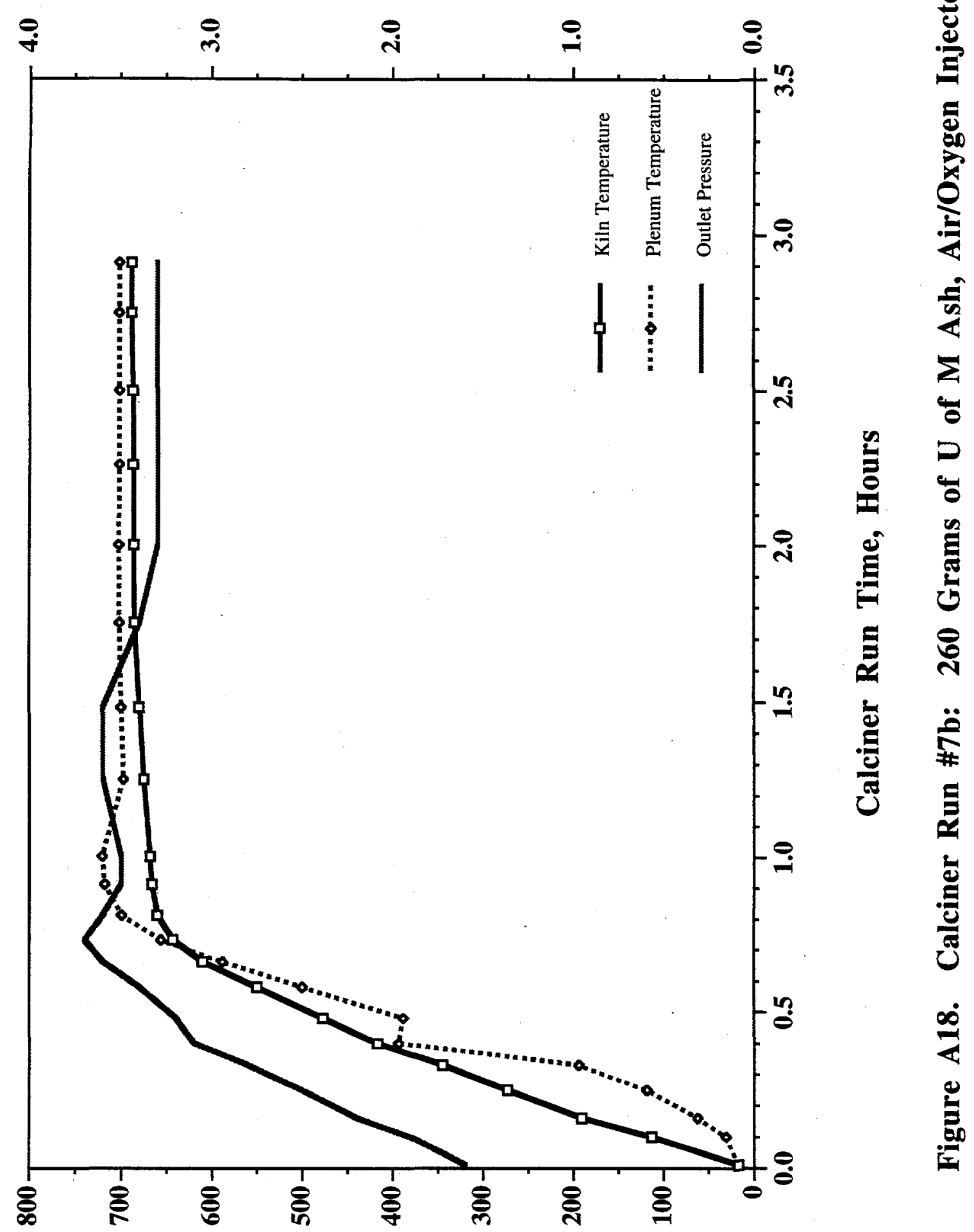

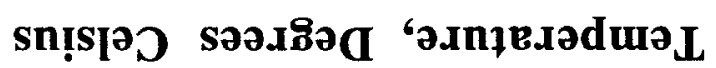




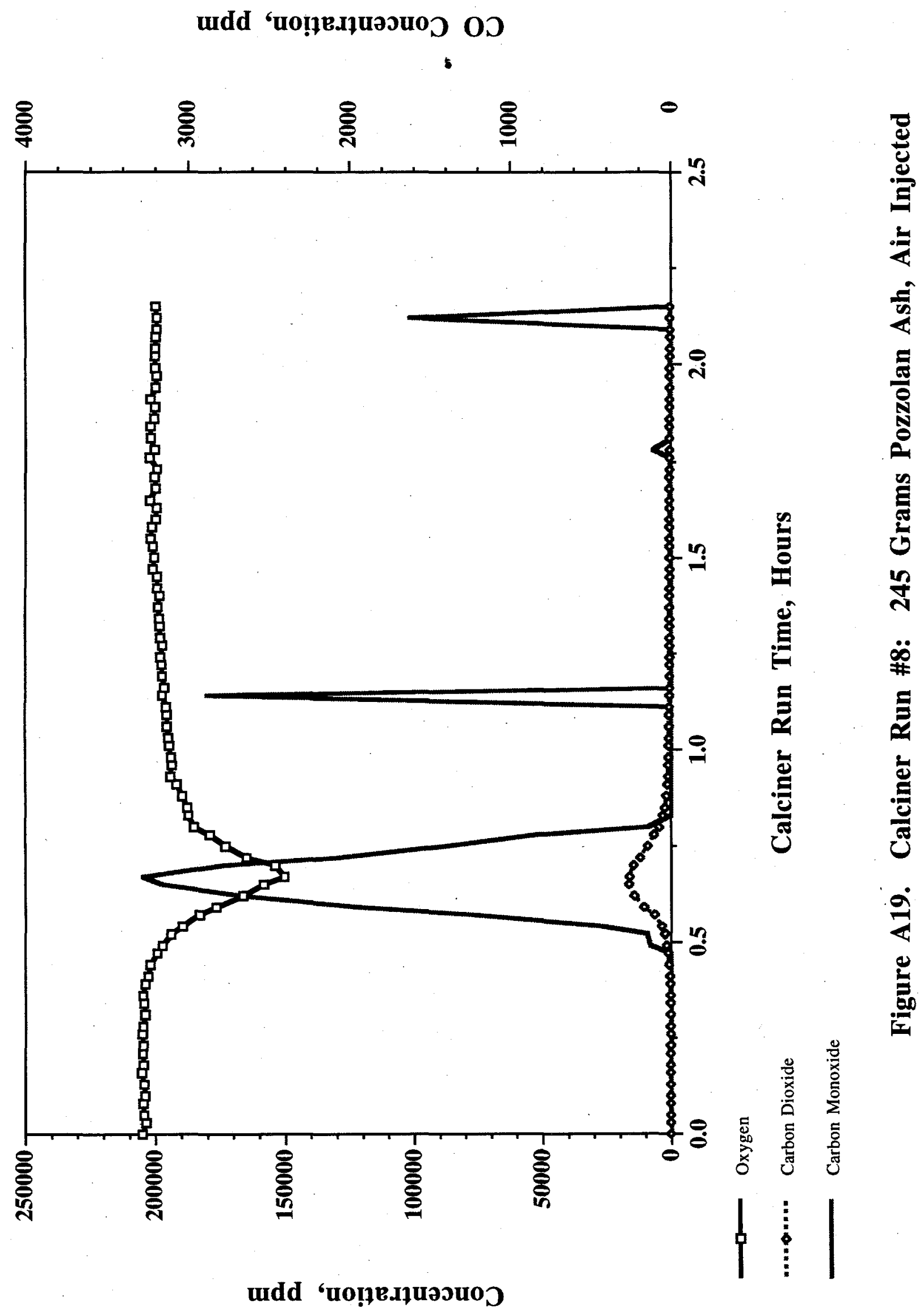

A. 19 


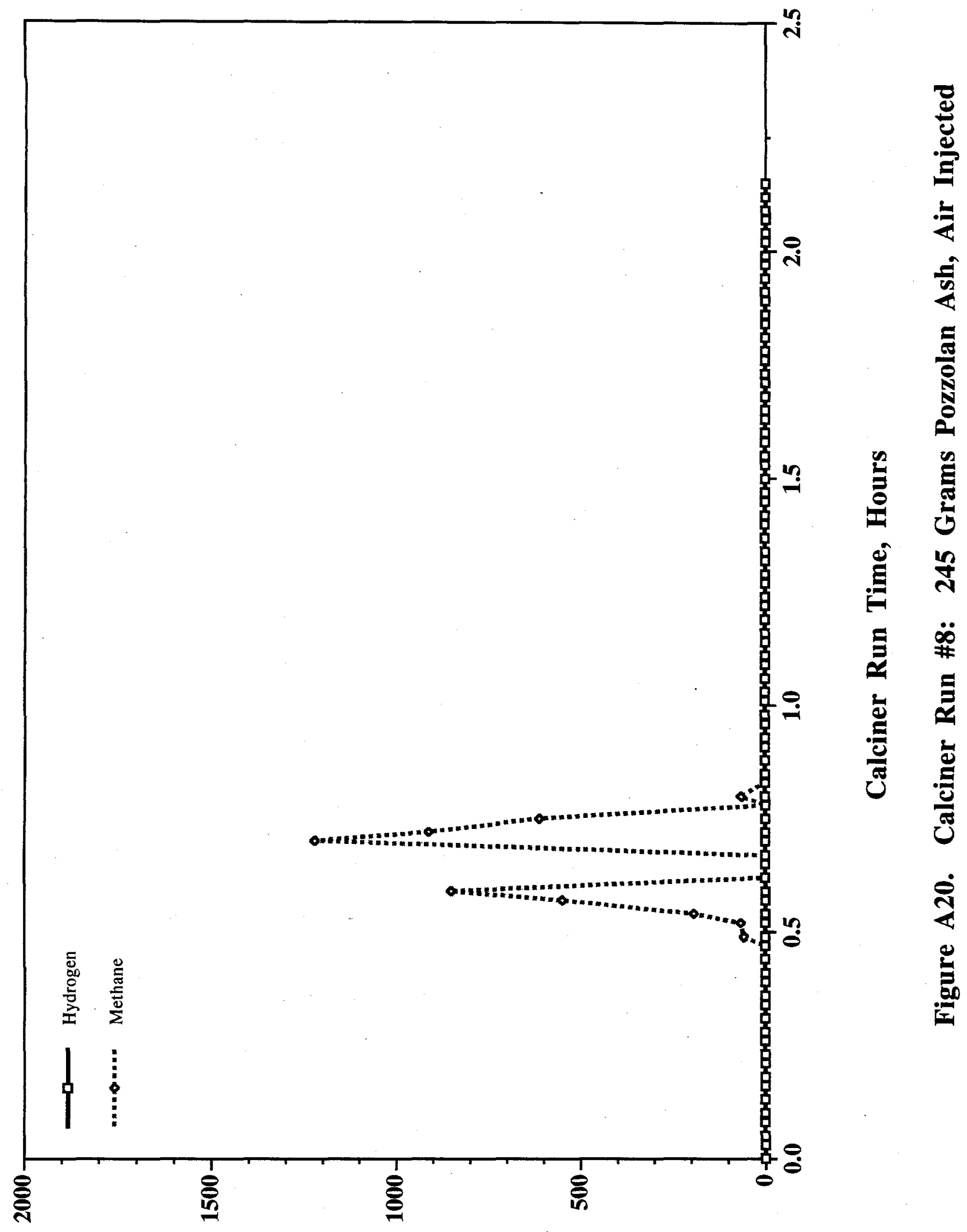

udd 'uo!̣e.jpuววนoว 


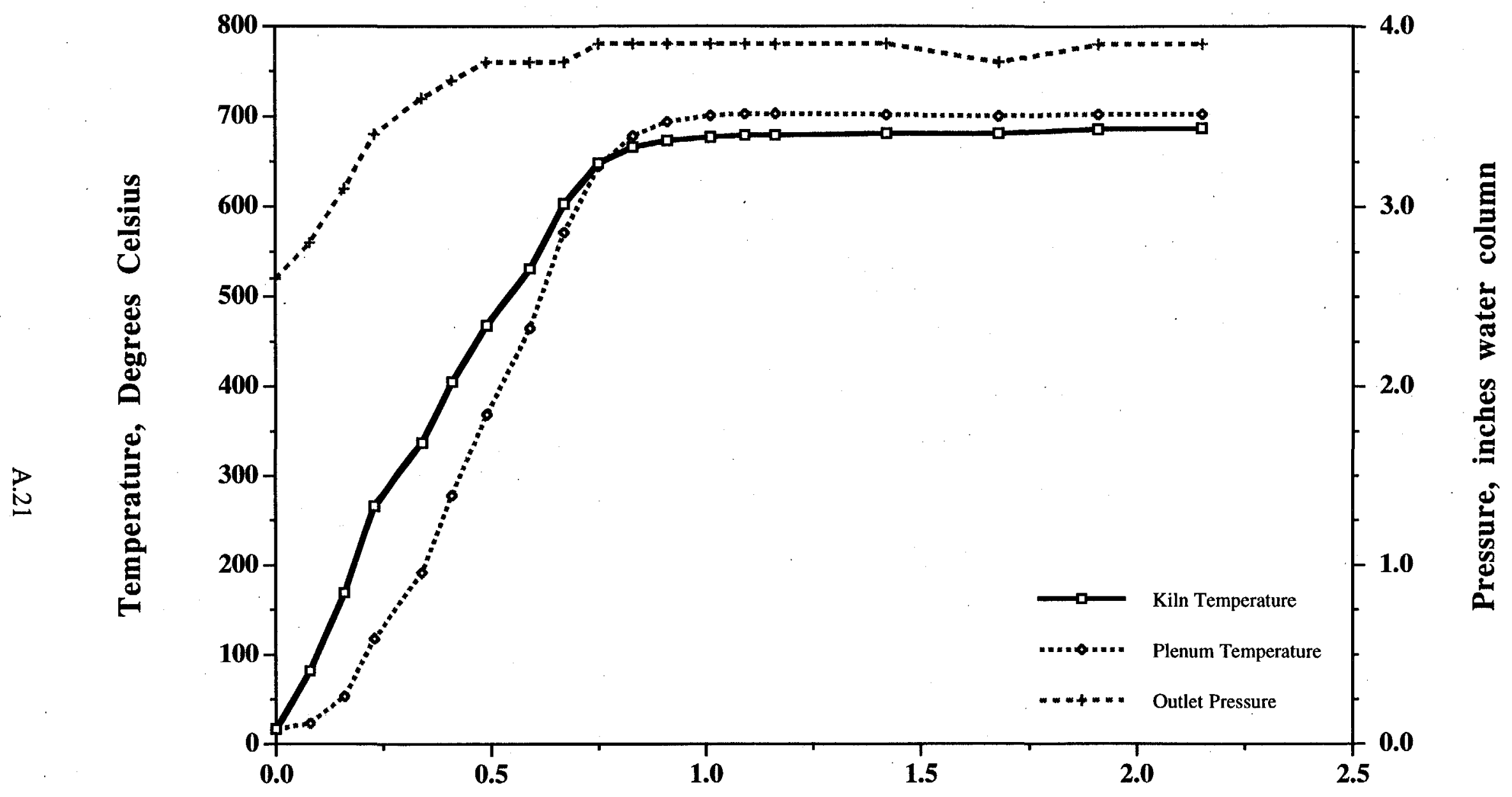

Calciner Run Time, Hours

Figure A21. Calciner Run \#8: 245 Grams Pozzolan Ash, Air Injected 


\section{udd 'uo!̣enuəouo}

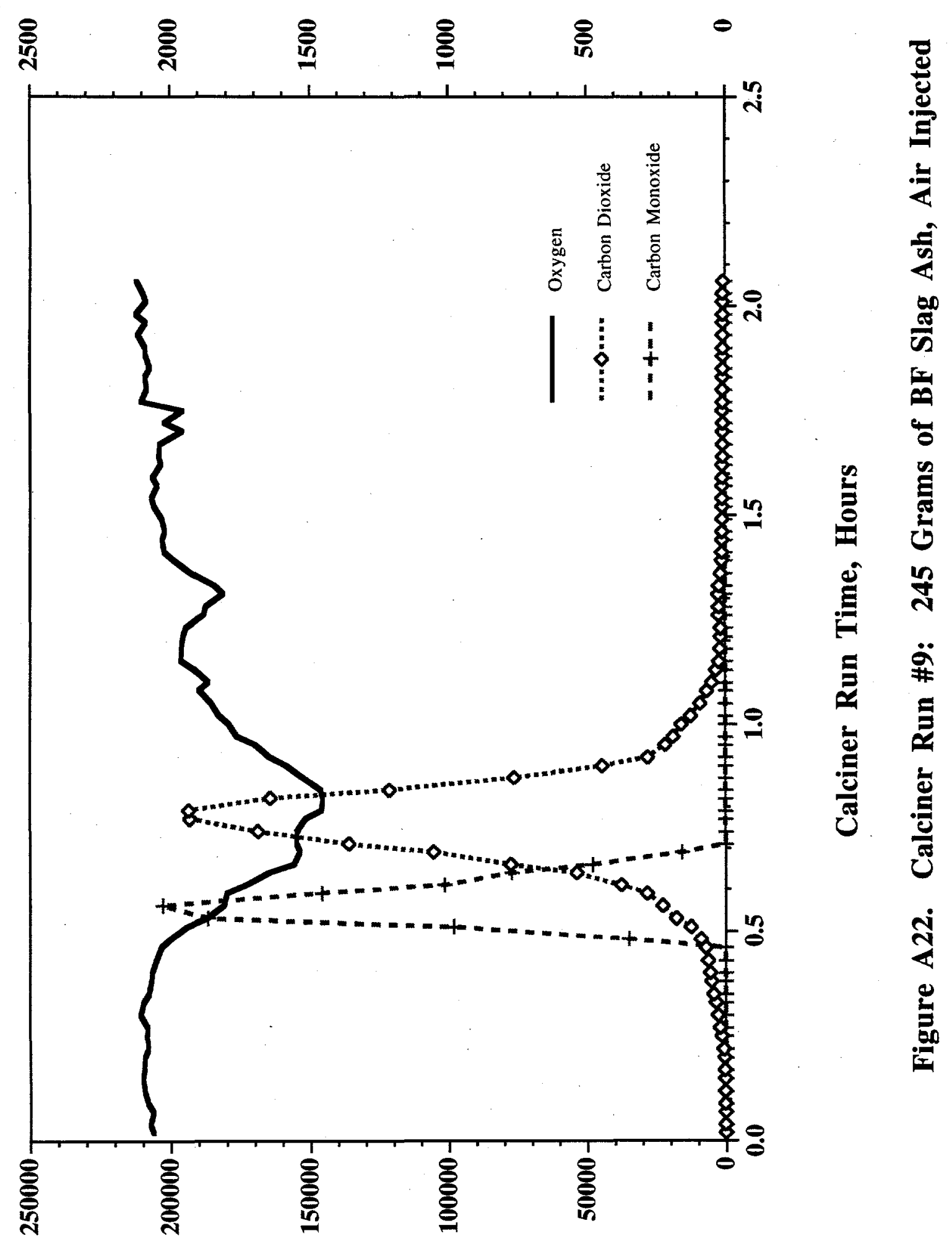

udd 'uo!̣edpuəวuo 


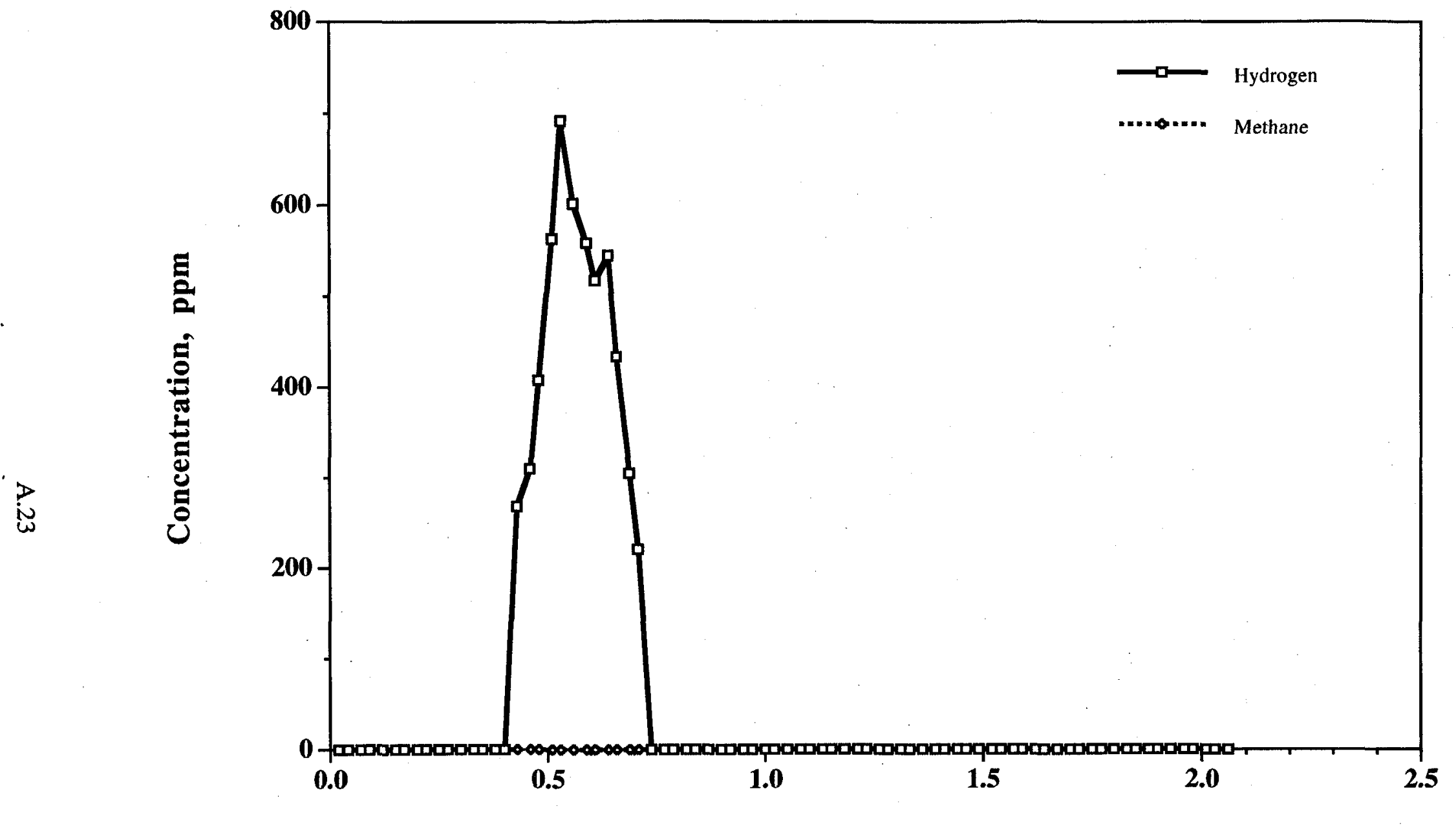

Calciner Run Time, Hours

Figure A23. Calciner Run \#9: 245 Grams of BF Slag Ash, Air Injected 


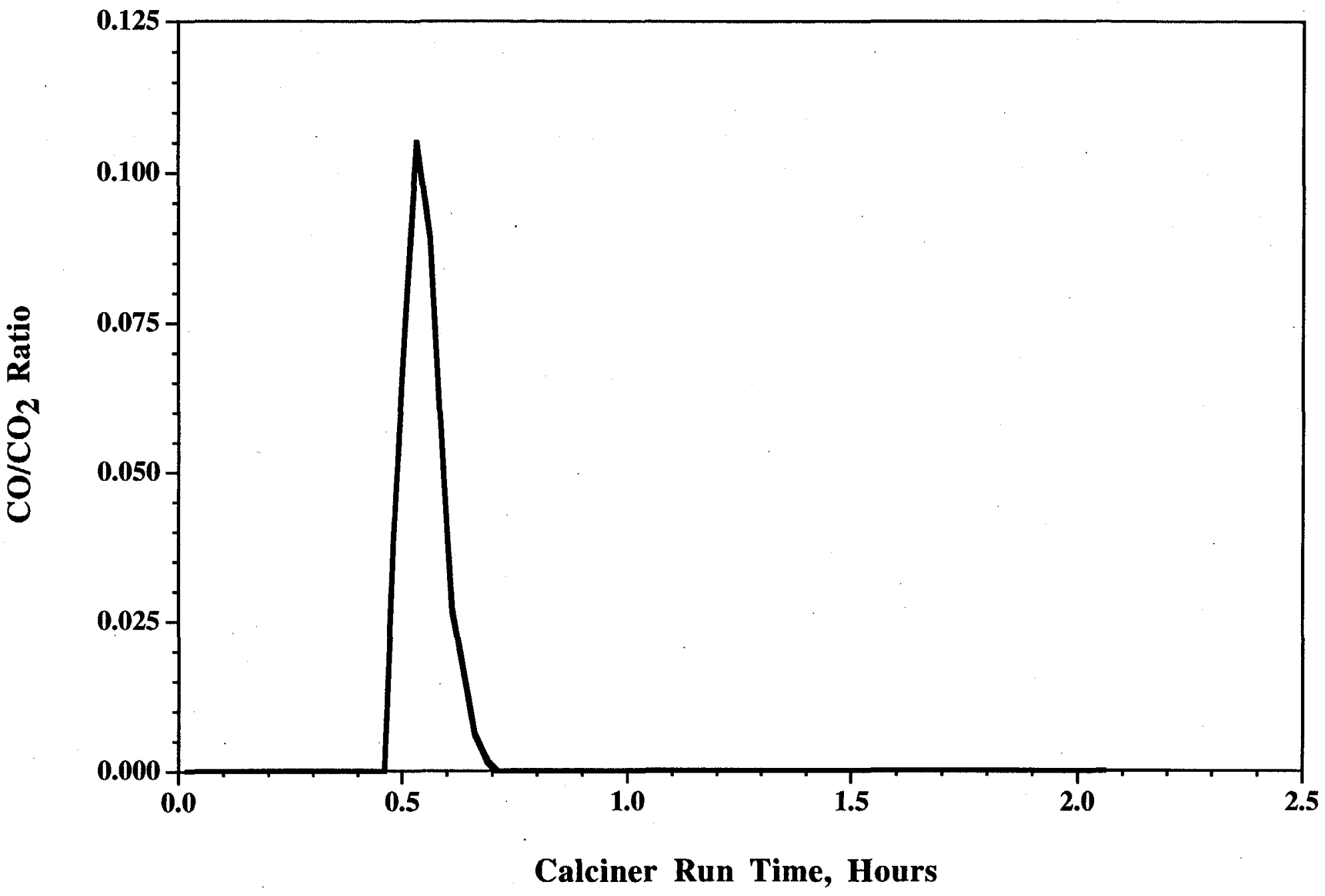

Figure A24. Calciner Run \#9: 245 Grams of BF Slag Ash, Air Injected 


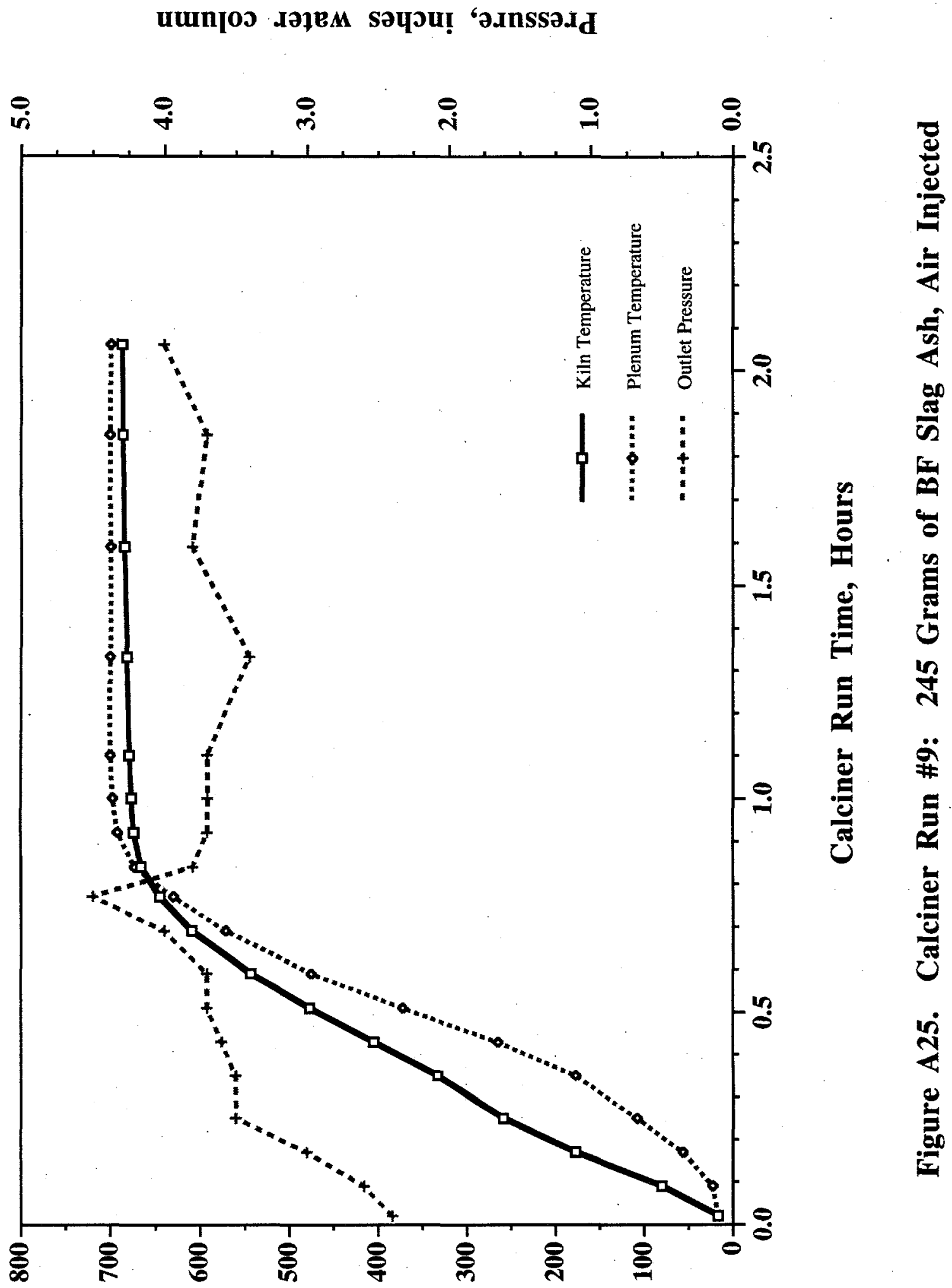

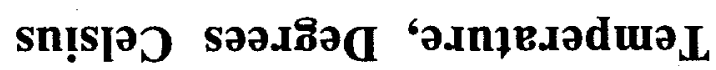




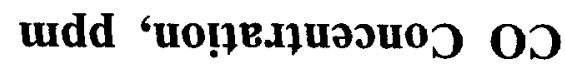

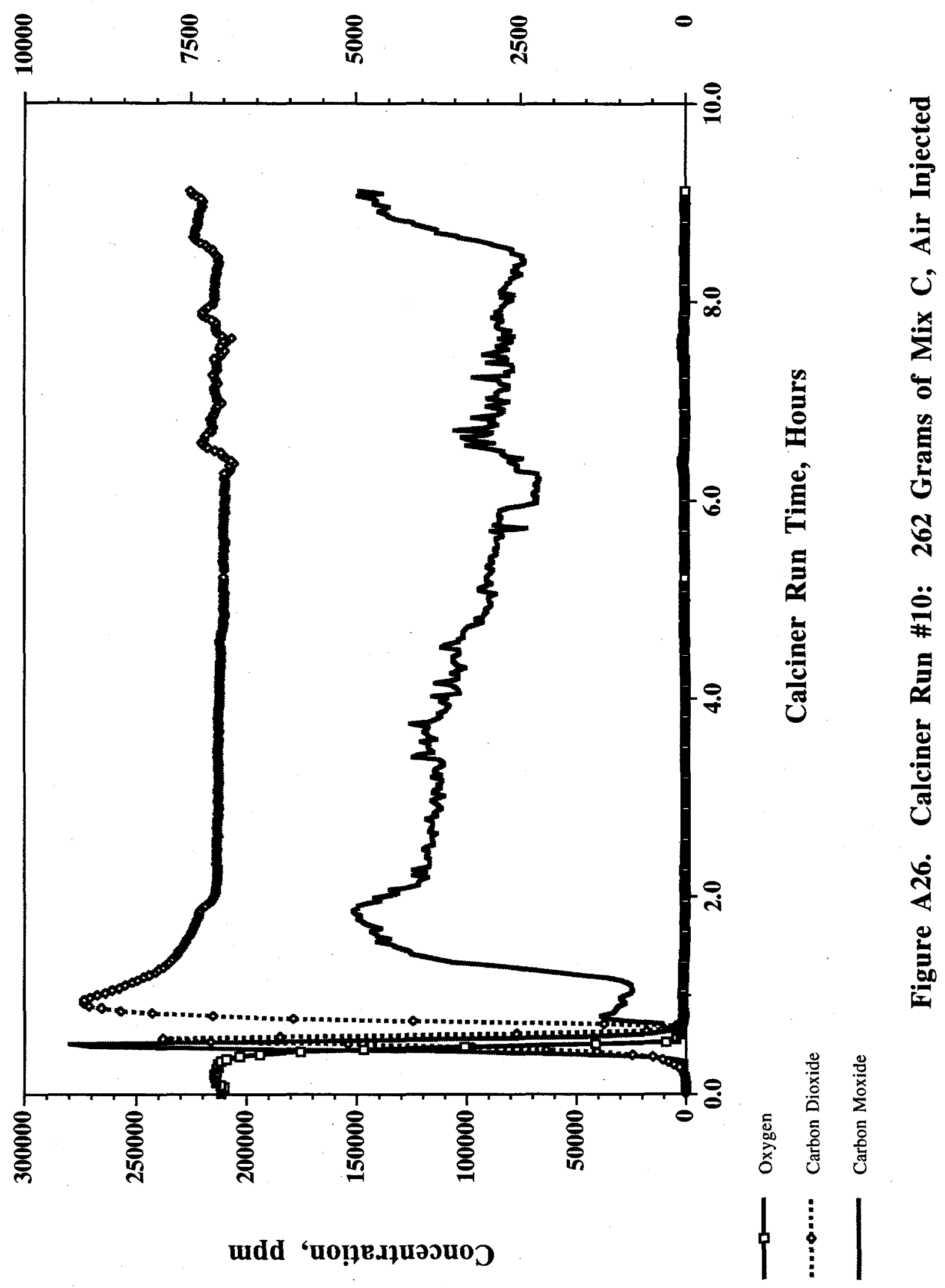




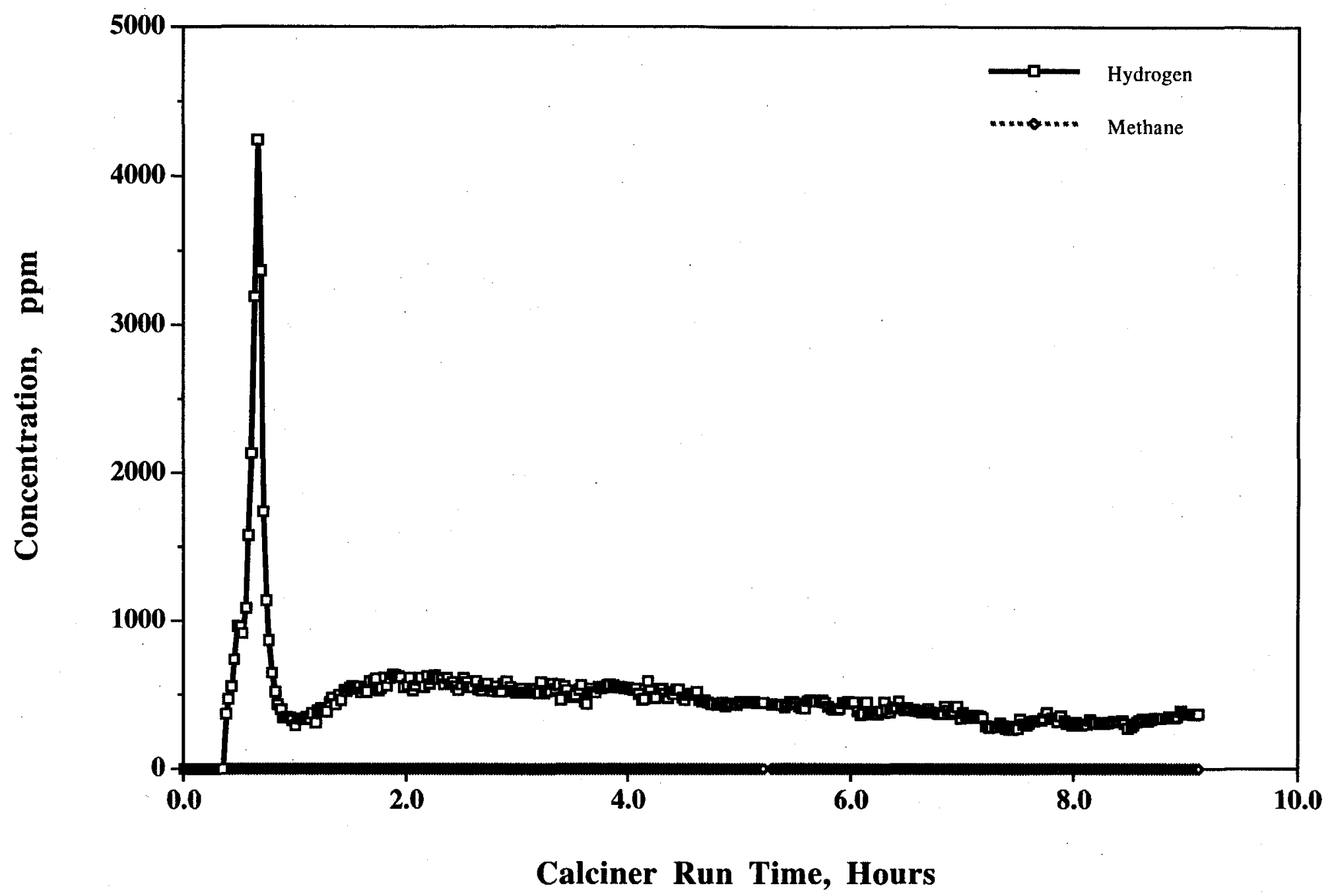

Figure A27. Calciner Run \#10: 262 Grams of Mix C, Air Injected 


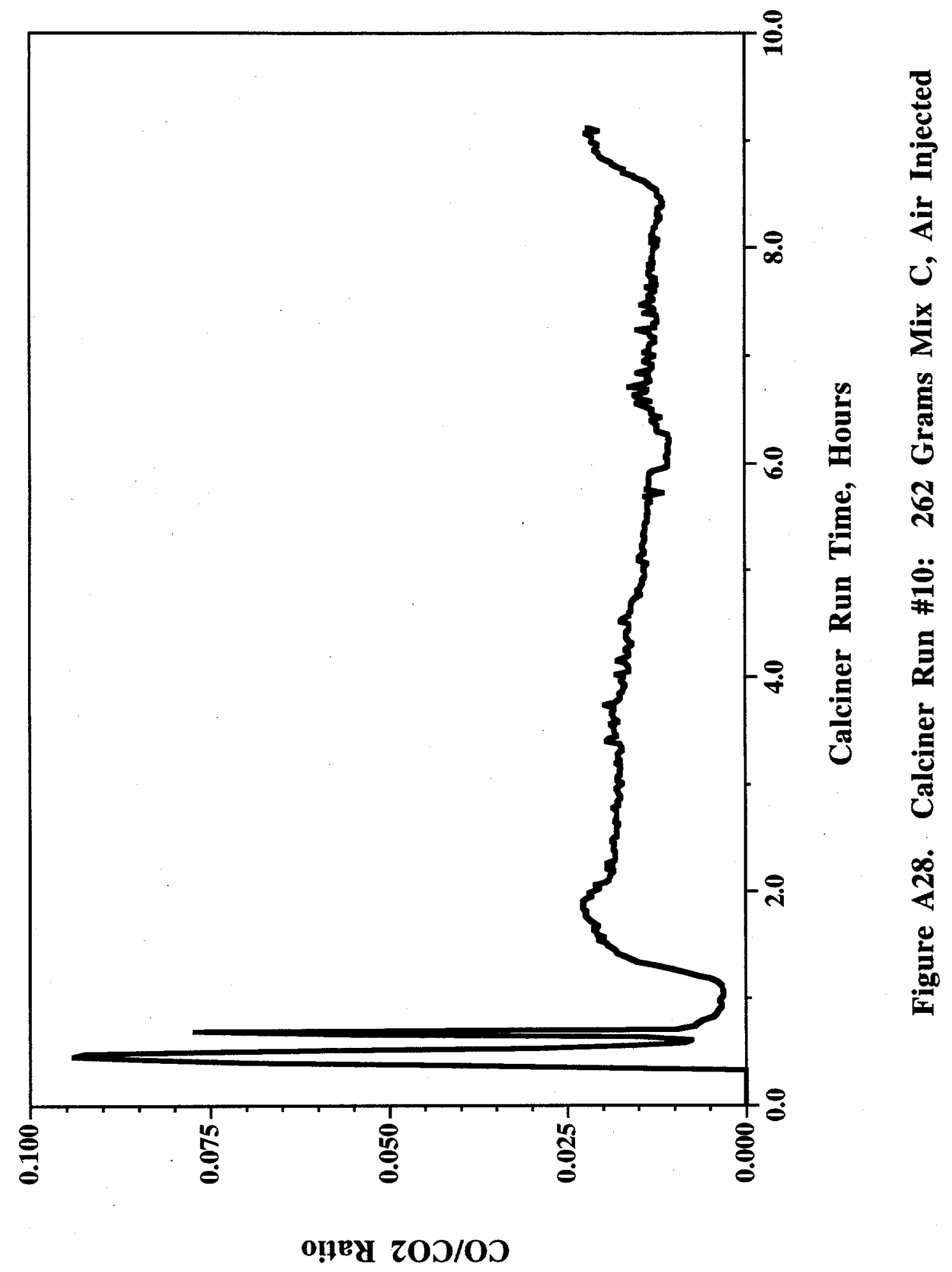


Temperature, Degrees Celsius

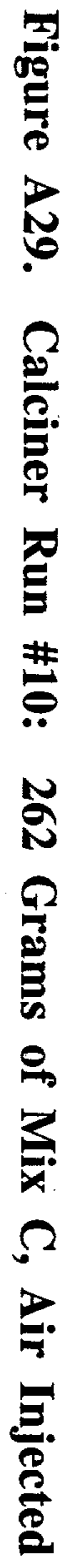

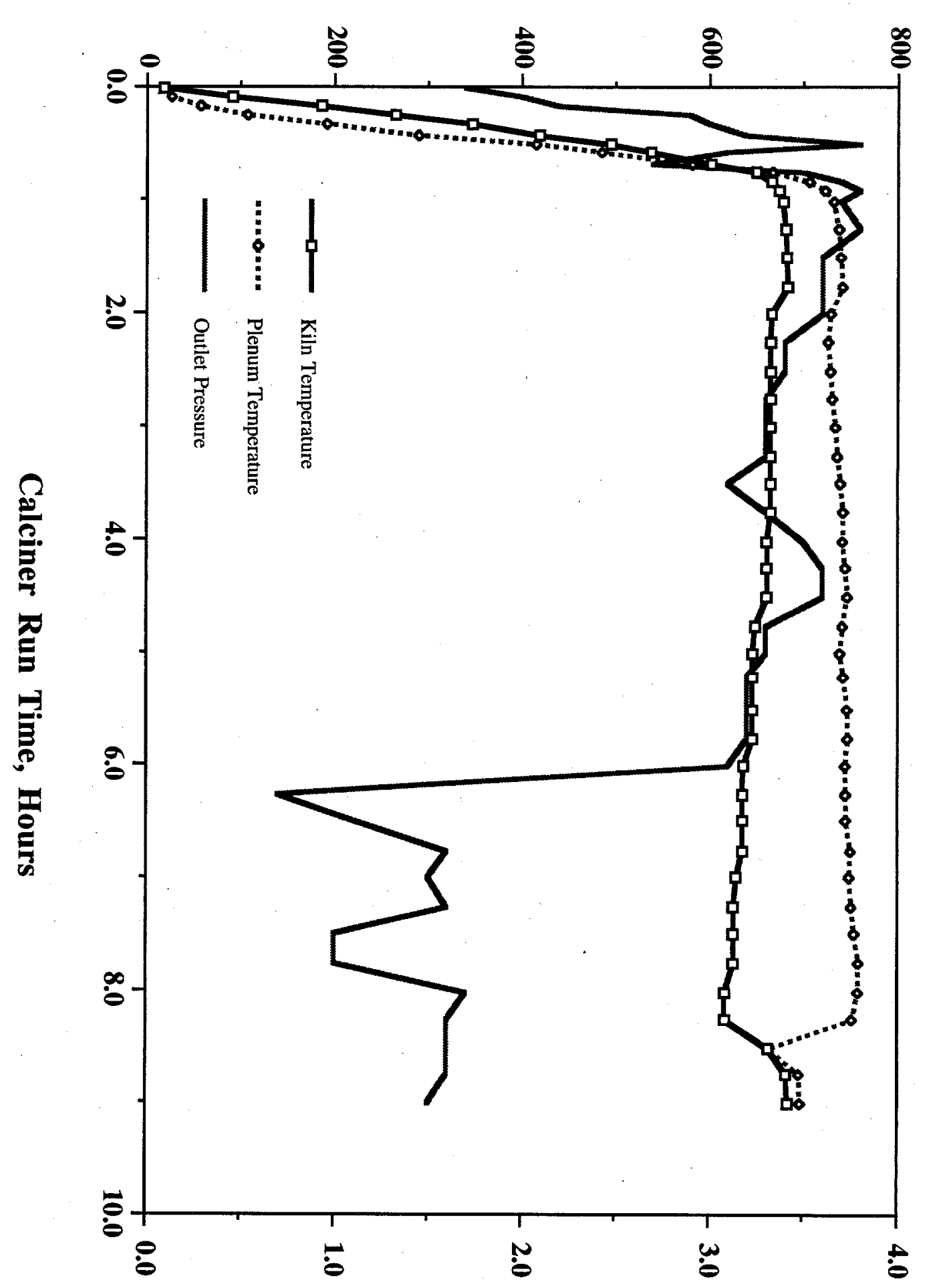

Pressure, inches water column 


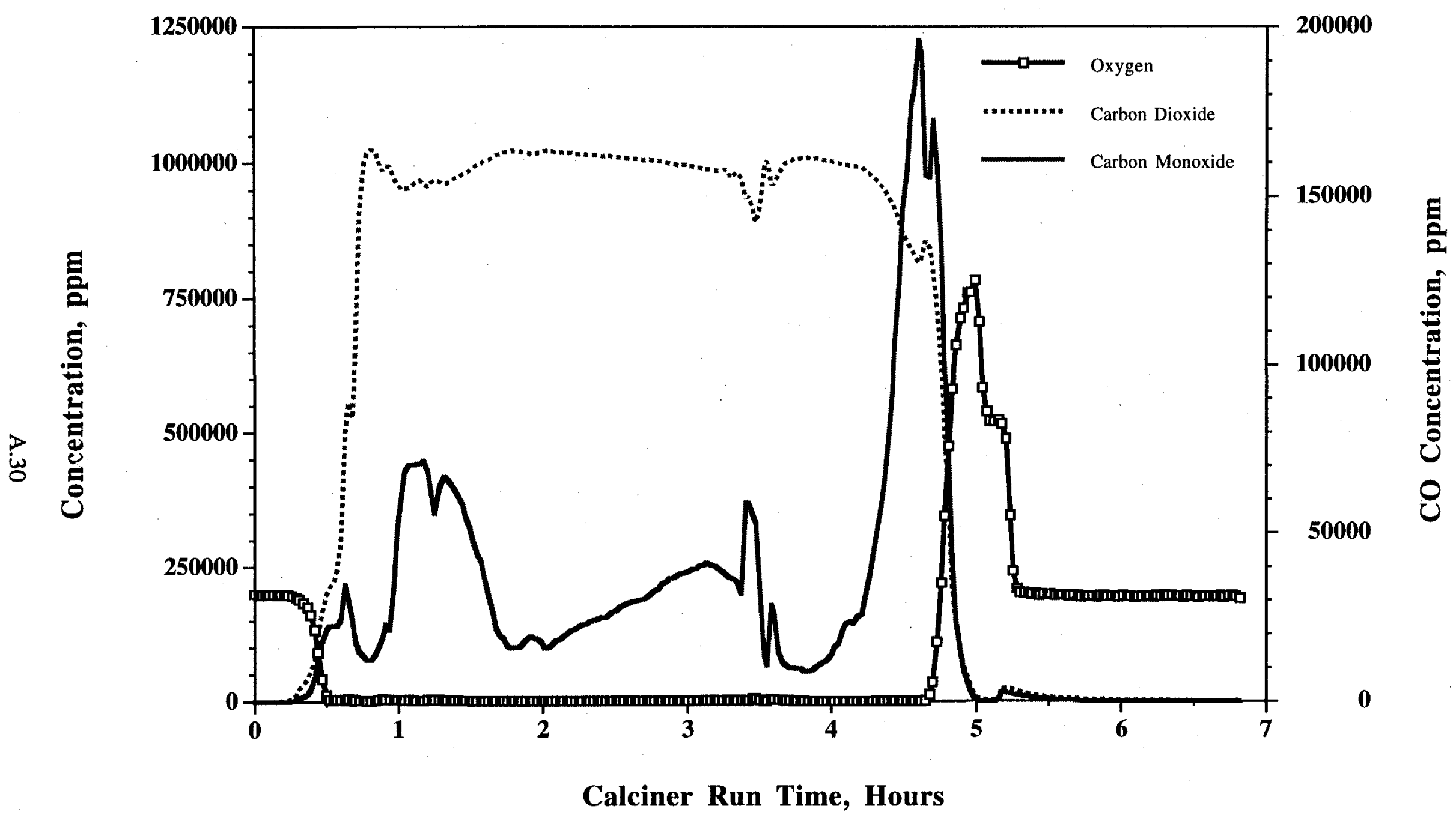

Figure A30. Calciner Run \#11: 242 Grams of Mix B, Air/Oxygen Injected 


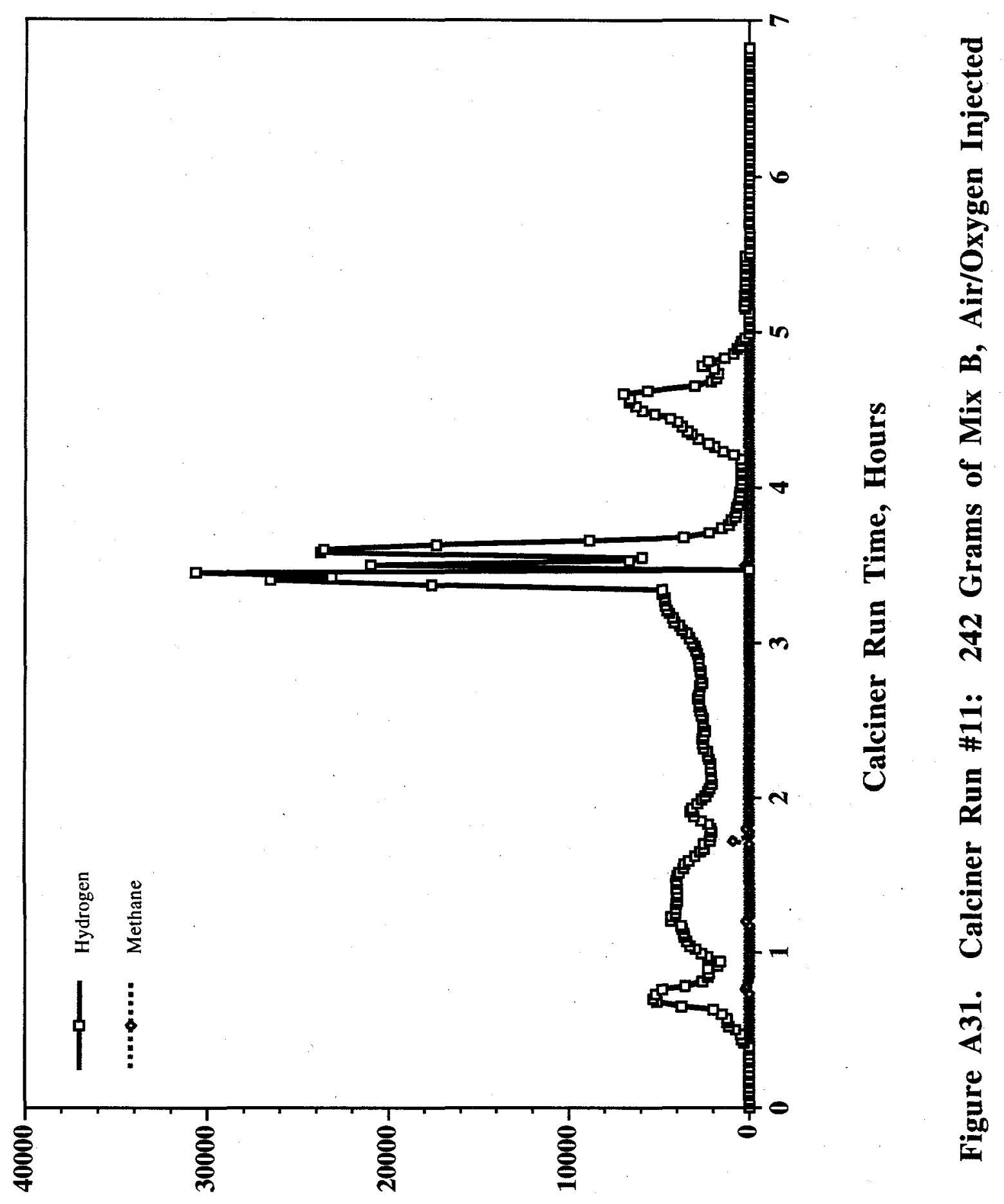

undd 'uo!̣tenuวouo 


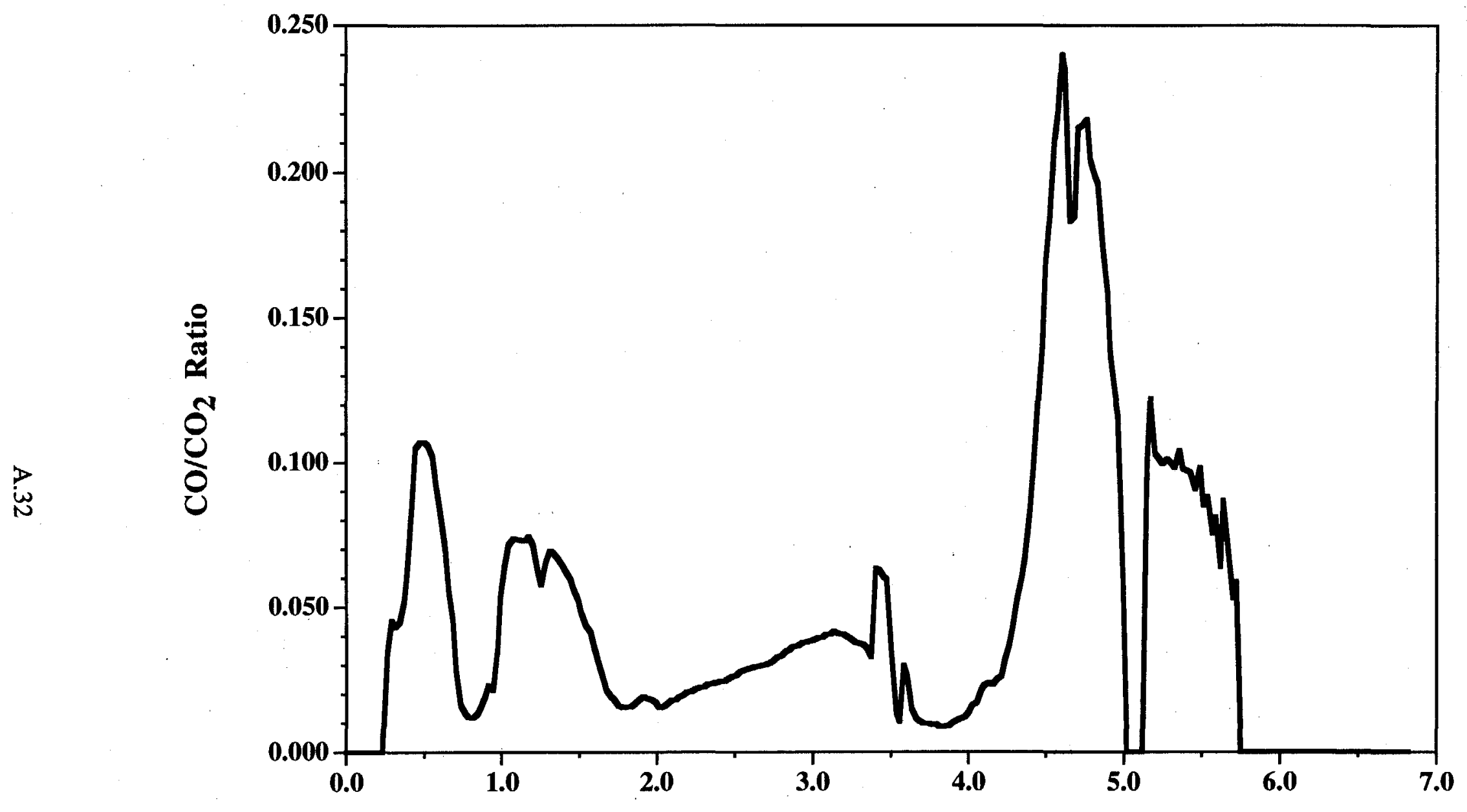

Calcines Run Time, Hours

Figure A32. Calciner Run \#11: 242 Grams of Mix B, Air/Oxygen Injected 


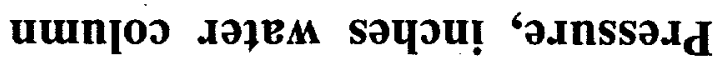

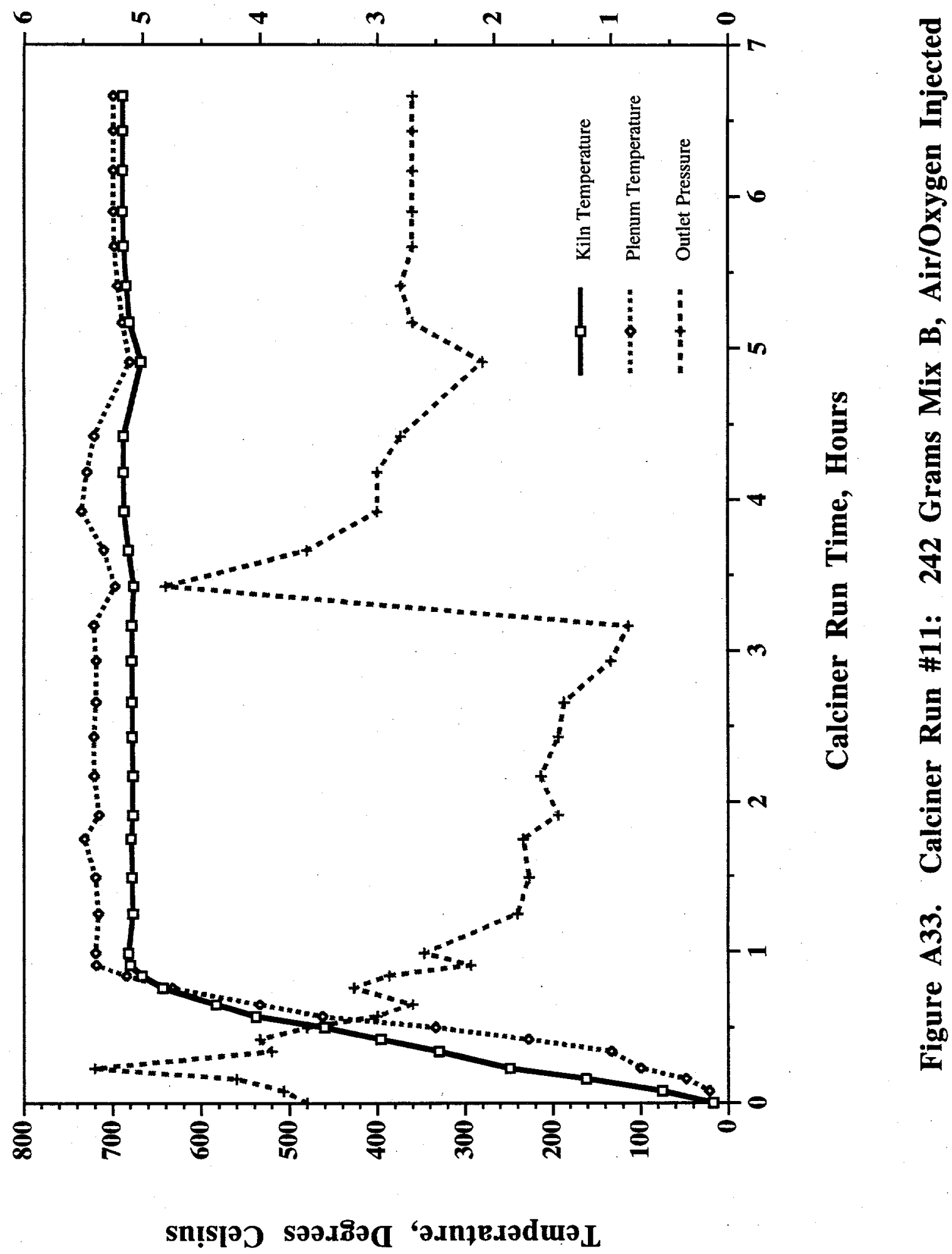




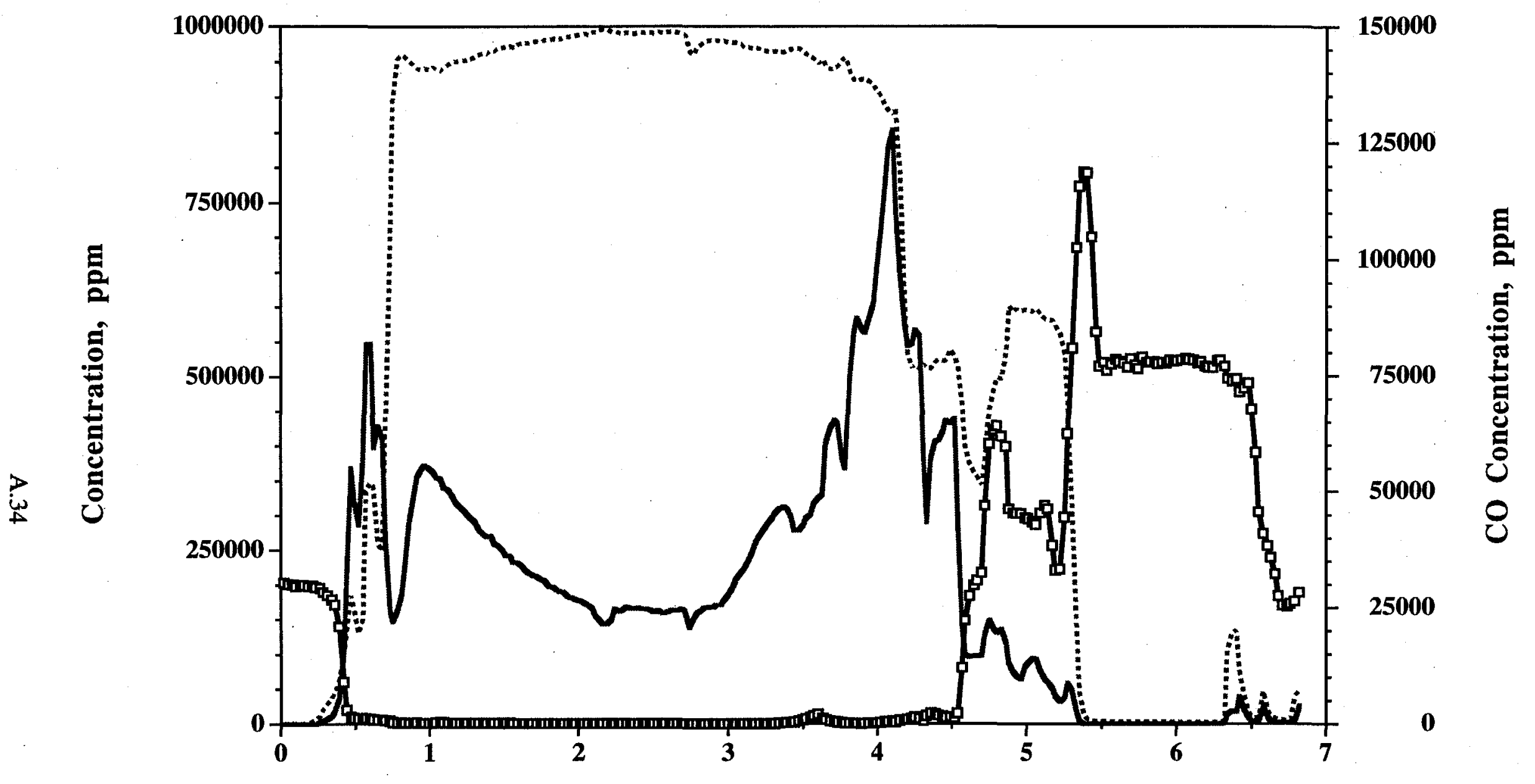

Oxygen

Carbon Dioxide

Calciner Run Time, Hours

Carbon Monoxide

Figure A34. Calciner Run \#12: 250 Grams of Mix D, Air/Oxygen Injected 


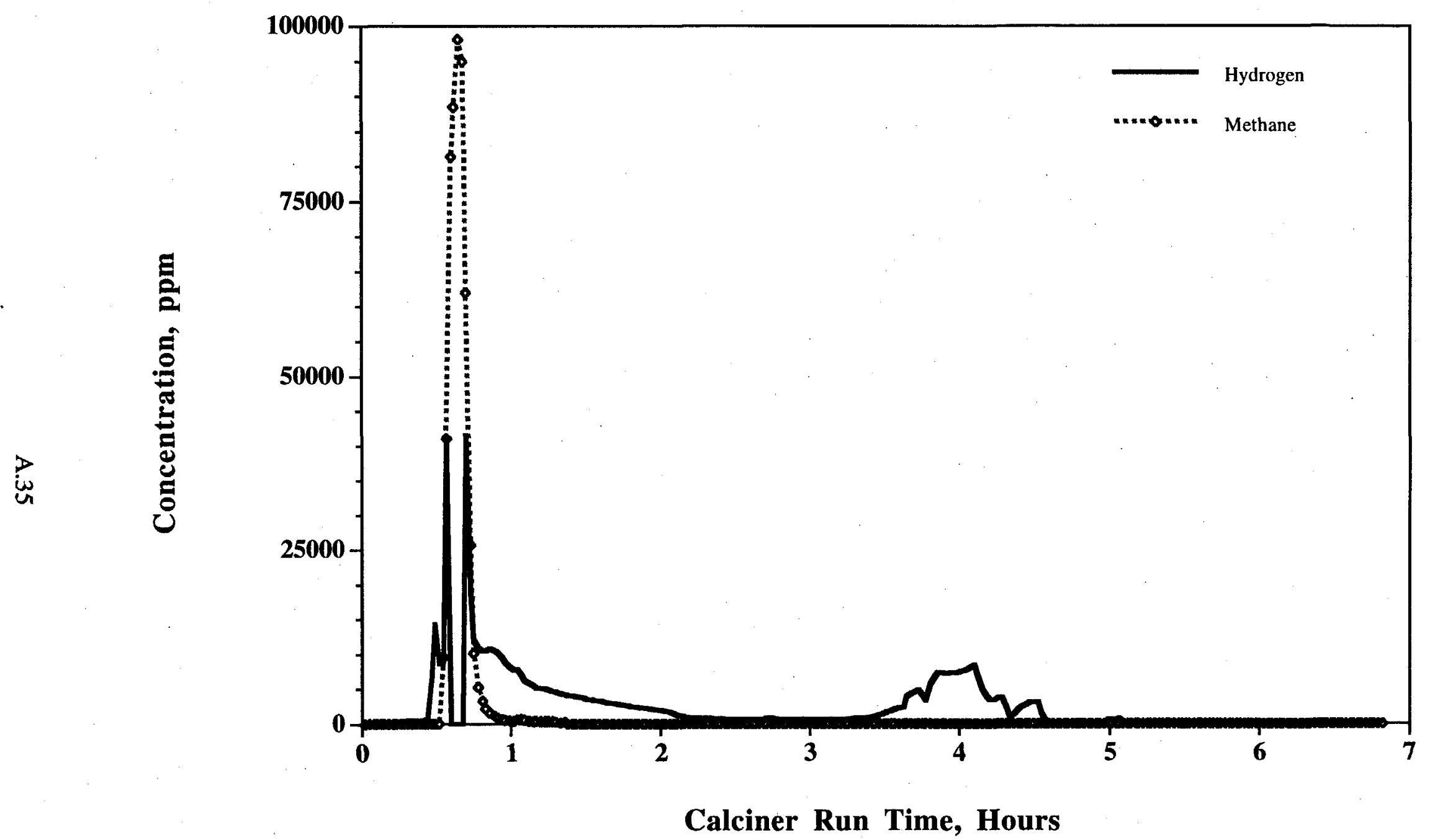

Figure A35. Calciner Run \#12: 250 Grams of Mix D, Air/Oxygen Injected 


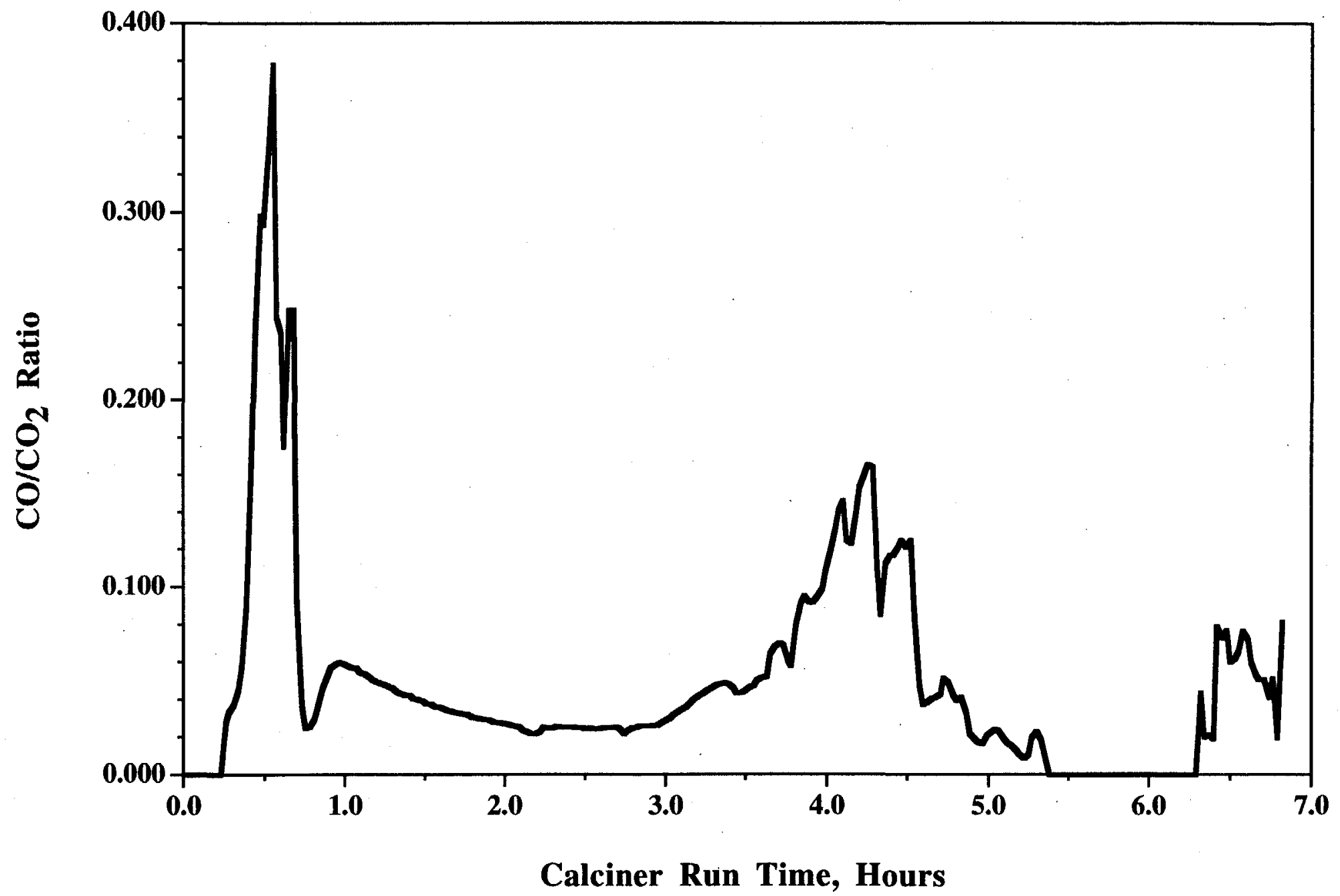

Figure A36. Calciner Run \#12: 250 Grams of Mix D, Air/Oxygen Injected 


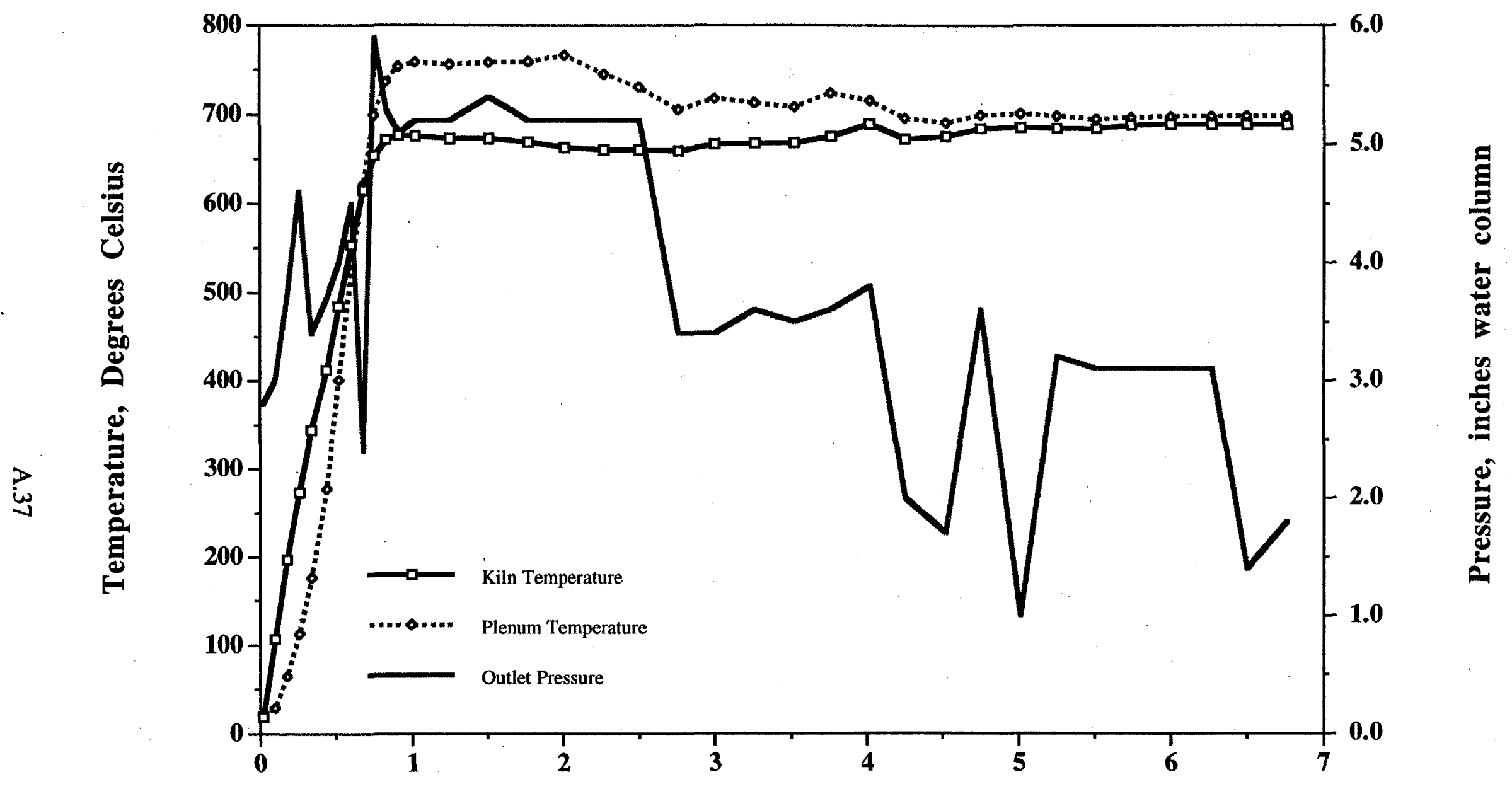

Calciner Run Time, Hours

Figure A37. Calciner Run \#12: 250 Grams of Mix D, Air/Oxygen Injected 


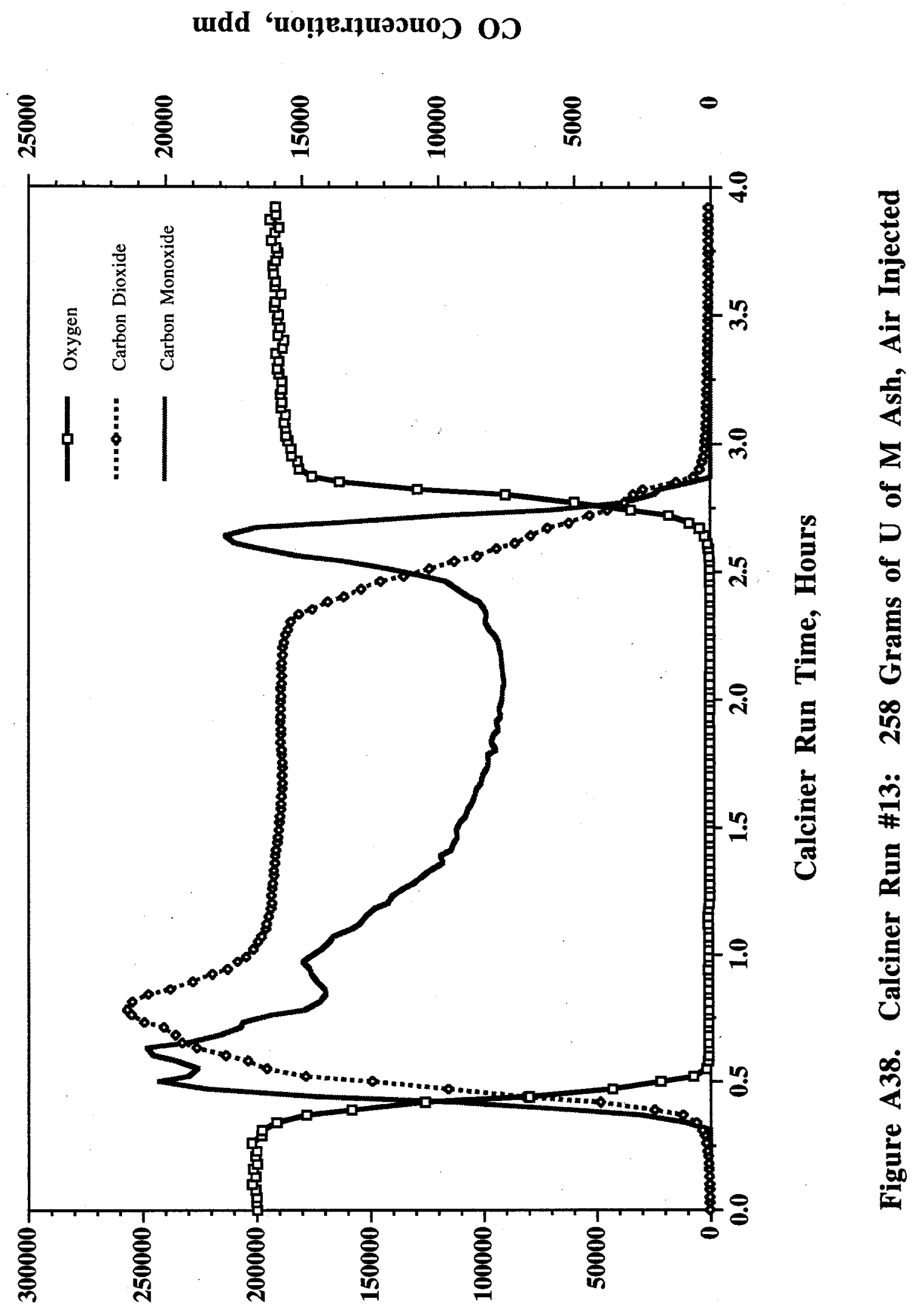

undd 'uo!̣e.łนววนоว 


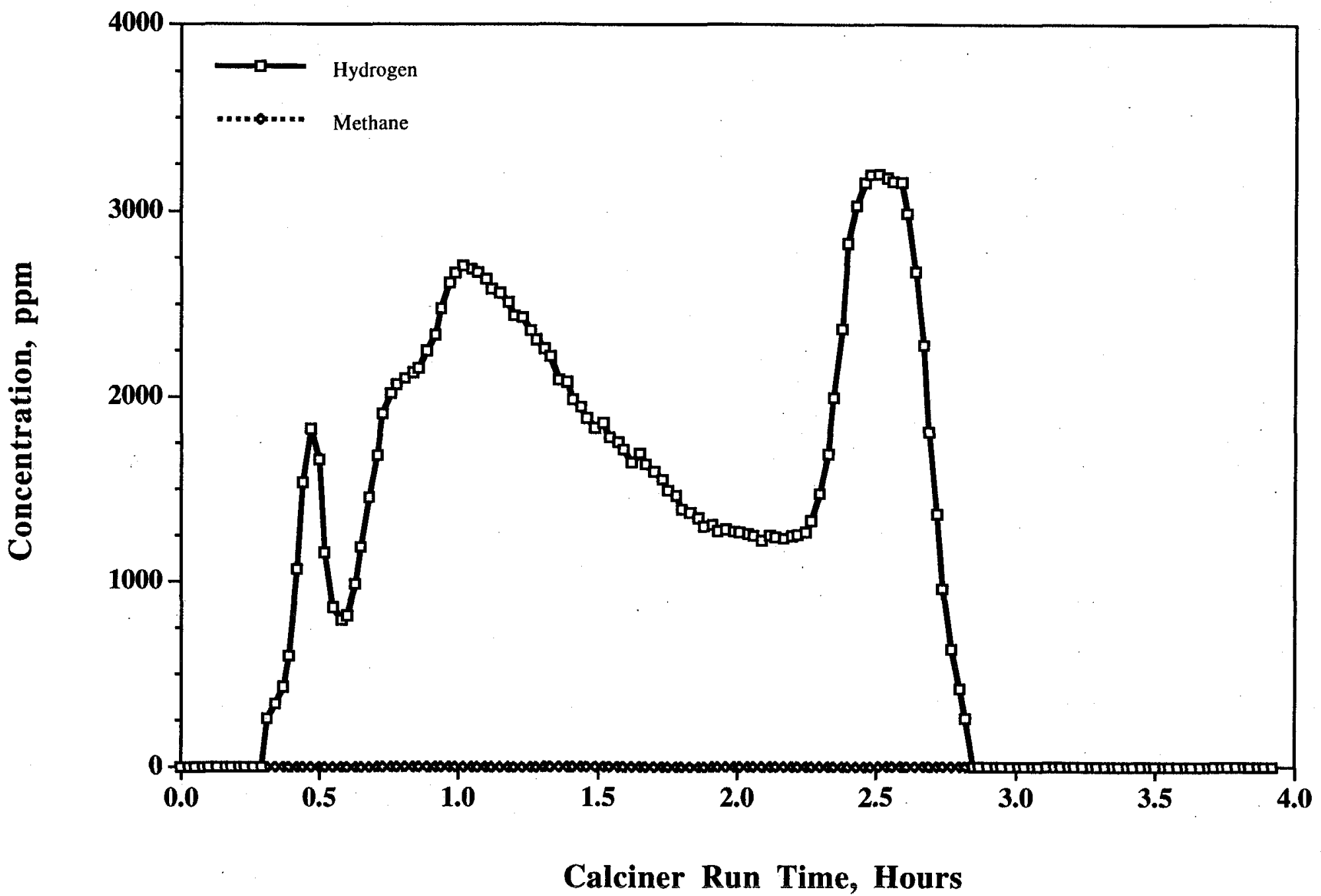

Figure A39. Calciner Run \#13: 258 Grams of $U$ of $M$ Ash, Air Injected 


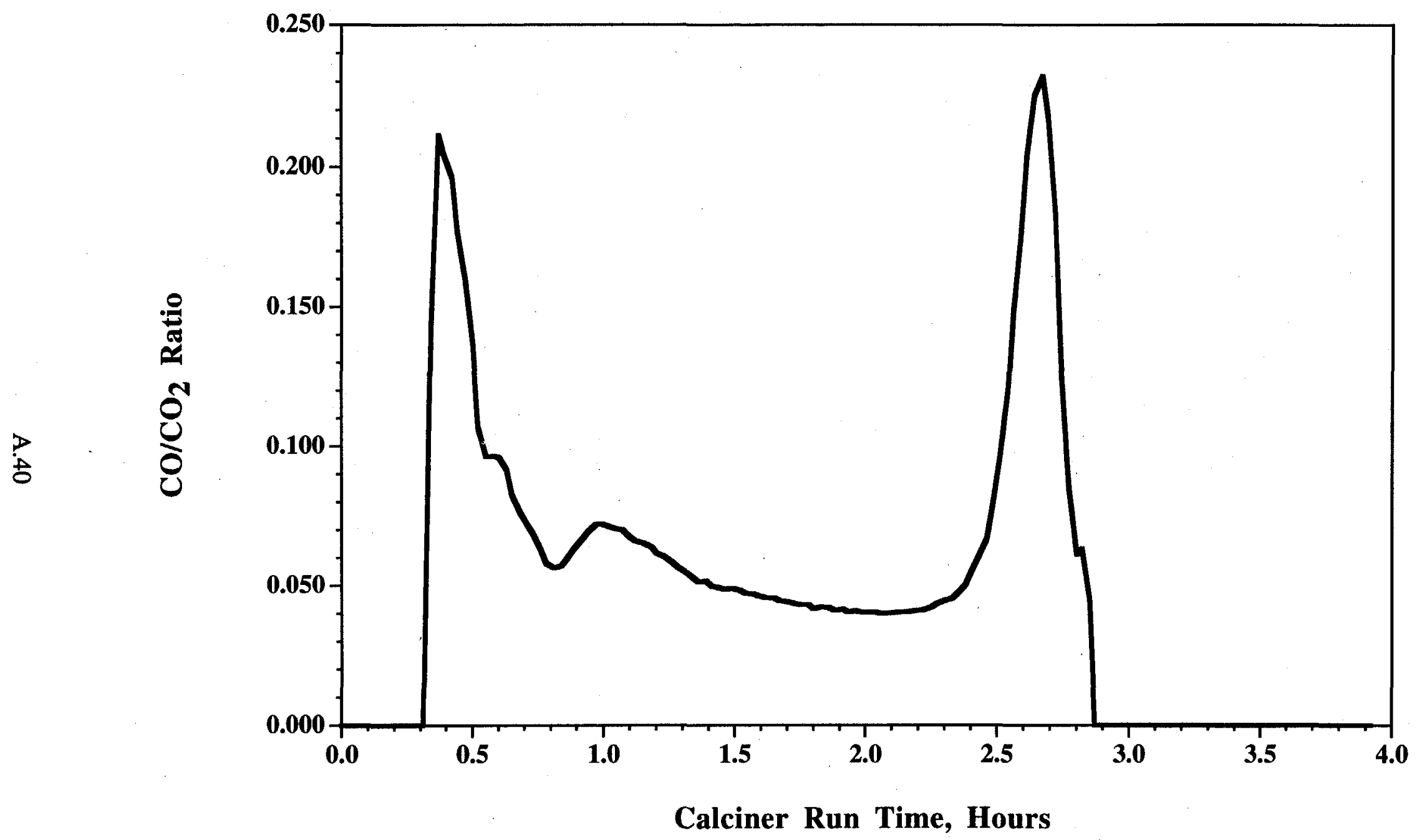

Figure A40. Calciner Run \#13: 258 Grams of $U$ of $M$ Ash, Air Injected 


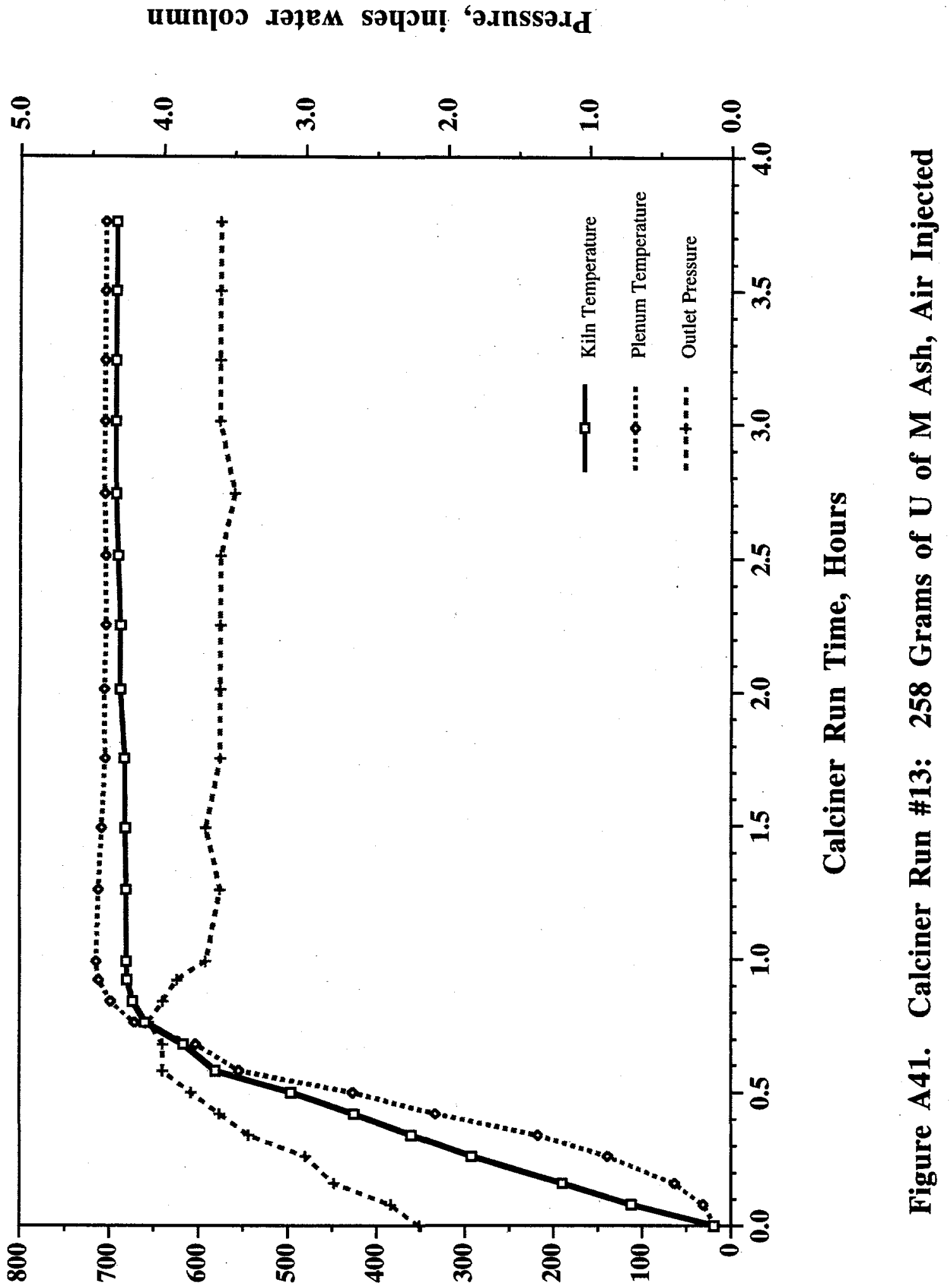

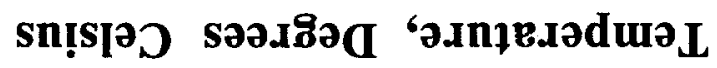

